\title{
An annotated catalogue of types of Silurian-Devonian brachiopod species from southern Belgium and northern France in the Royal Belgian Institute of Natural Sciences (1870-1945), with notes on those curated in other Belgian and foreign institutions
}

\author{
BERNARD MOTTEQUIN
}

O.D. Earth and History of Life, Royal Belgian Institute of Natural Sciences, rue Vautier, 29, B-1000 Brussels, Belgium; bmottequin@naturalsciences.be.

\begin{abstract}
The type material of 45 Pridolian-Devonian brachiopod species, described in southern Belgium and northern France (1870-1945) and curated at the Royal Belgian Institute of Natural Sciences (Brussels), is re-investigated and illustrated in order to facilitate future taxonomic revision; such a catalogue should allow a better assessment of the brachiopod diversity during the considered time span. Furthermore, 28 other Silurian-Devonian species originally described in Belgium (1850-1950), but housed in other Belgian or foreign institutions, are also discussed. For taxonomical purposes, the lectotypes of several species are selected; the latter were described by Asselberghs (Stropheodonta couviniensis, Plethorhyncha percostata var. gdoumontensis, Athyris dorlodoti, Retzia gdoumontensis, Dielasma maillieuxi), Béclard (Orthis dorsoplicata, Orthis musischura, Rhynchonella parvula (non R. parvula Eudes-Deslongchamps)), de Ryckholt (Lingula amayana), Dewalque (Crania corneti), and Maillieux (Discina (Discina) forrierensis, Pholidostrophia extensa, Anoplia theorassensis, Schuchertella durbutensis, Streptorhynchus rahiri, Pentamerus loei). Re-investigation of the ambocoeliid Spirifer pentameroides Stainier highlighted the homonymy between Diazoma Dürkoop, 1970 (Brachiopoda) and Diazoma Lamarck, 1816 (Tunicata); the former genus must be rejected and replaced by a valid synonym, namely Kelusia Mamedov, 1978.
\end{abstract}

KEYWORDS: Brachiopoda, Pridoli, Devonian, Belgium, France.

\section{Introduction}

The Silurian (Pridoli) and Devonian marine succession of southern Belgium and northern France (Fig. 1) is particularly rich in invertebrates and notably in brachiopods (northern France means herein the area comprised between Mondrepuis (Aisne), to the west and Givet (Ardennes), to the east). This geographically restricted area is famous worldwide as several internationally recognized Devonian stages were firstly defined there such as the Givetian and the Famennian. During the interval ranging from 1870 to 1945 , numerous new brachiopod species and varieties were erected on the basis of material from this area especially by E. Asselberghs (1889-1959) and E. Maillieux (1875-1946); the type material of most of them is now curated at the Royal Belgian Institute of Natural Sciences (Brussels). Whereas international palaeontological databases are built for assessing the evolution of the biodiversity through time, many of these brachiopod species and 'varieties' described in the course of the second half of the $19^{\text {th }}$ century and the first half of the $20^{\text {th }}$ century have never been revised so far; they are still only known by embellished drawings or poor-quality photographs.
The aim of this paper is to contribute to the assessment of the brachiopod diversity during the considered stratigraphic timespan in promoting and facilitating future taxonomic studies. For this reason, the type material of almost each species deposited at Brussels is illustrated photographically (sometimes for the first time) and discussed. For the species which remain poorly known notably due to the deficient state of preservation of the type material and/or limited material, this annotated catalogue should be considered only as a first step in their reassessment, pending the study of further material. Moreover, other species originally described in Belgium (1850-1950), but curated in Belgian universities and foreign institutions (France, Germany, USA), are also discussed.

\section{Stratigraphy}

At the end of the Silurian (Pridoli) and during the Devonian, southern Belgium and northern France were located along the southeastern margin of Laurussia. Pridolian units developed on the margins of the Cambro-Ordovician Givonne and Stavelot massifs (Fig. 1) were notably discussed by Vandenven (1991), Godefroid (1995a), Godefroid \& Cravatte (1999), Belanger \& Ghysel (2017),

Figure 1. Location and schematic geological map of southern Belgium and northern France with indication of the localities cited in the text (modified from de Béthune, 1954). Abbreviations: Am, Amay; As, Astenet; Bo, Boussuen-Fagne; $\mathrm{Bu}$, Bure; Ch, Chimay; Co, Couvin; D, Durbuy; E, Emines; Fa, Fauvillers; Fe, Ferrières; Gd, Gdoumont; Go, Godinne; Ha, Harzé; HSM-OTS, HaineSambre-Meuse Overturned Thrust Sheets (Belanger et al., 2012); Hu, Huccorgne; L, Longlier; Ma, Maurenne; Mo, Mondrepuis; Mu, Muno; N, Nouzonville; Ol, Olloy; Ov, Ovifat; Re, Recogne; Ro, Rochefort; Sa, Sautour; S-H, SaintHubert; So, Sombreffe; Ti, Tilff; Tr, Treignes; V-M, Vireux-Molhain; $\mathrm{W}$, Waimes (Weismes in German); Wi, Wihéries.

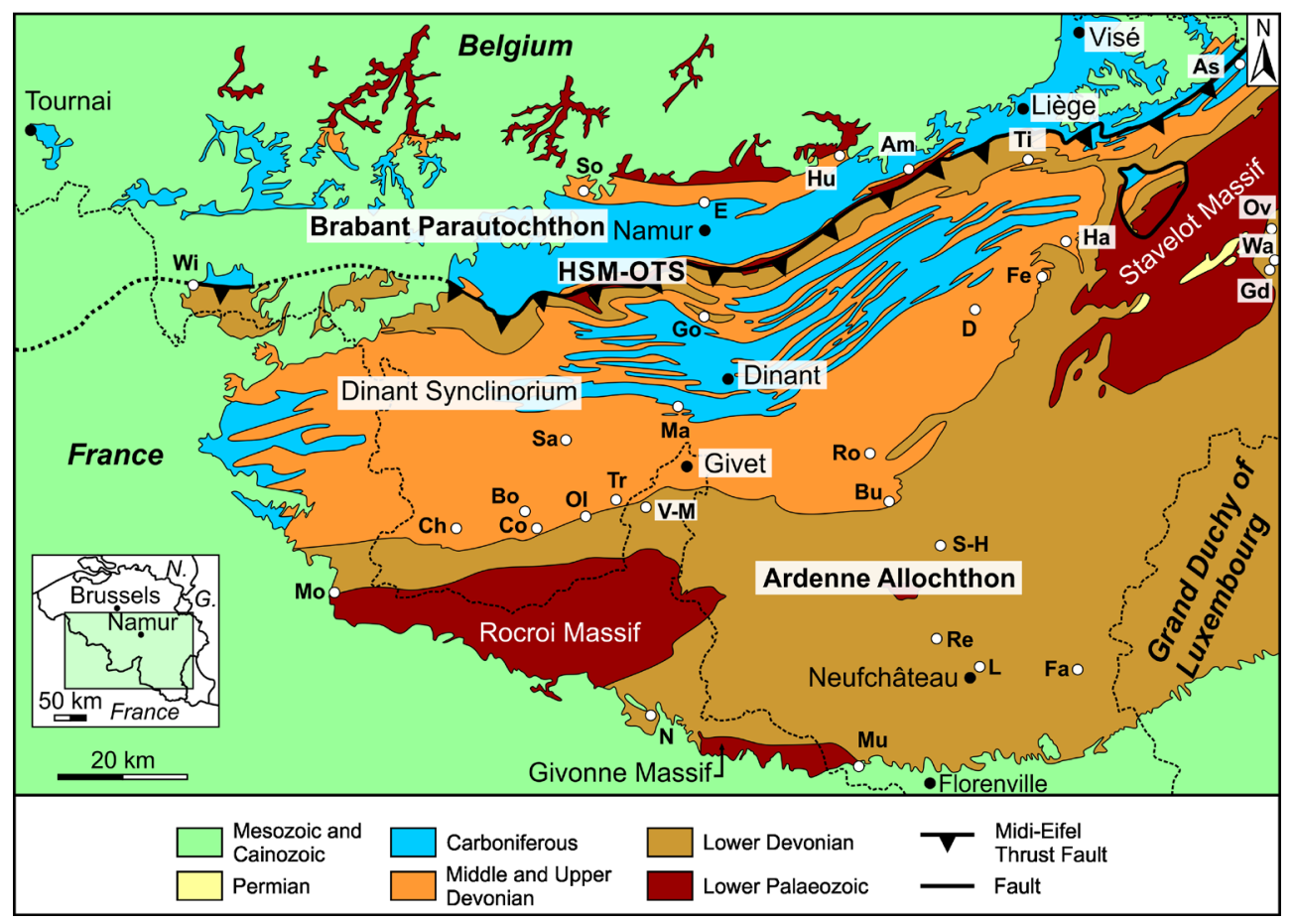


and Marion et al. (in press). The lithostratigraphy of the Devonian units recognized in the Brabant Parautochton, Haine-SambreMeuse Overturned Thrust Sheets, and the Ardenne Allochthon (Dinant Synclinorium only) (Fig. 1) (for more details related to these Variscan units, see Belanger et al., 2012) was described by Godefroid et al. (1994) (Lower Devonian), Bultynck et al. (1991) (Middle Devonian), and Boulvain et al. (1999) (Upper Devonian, Frasnian only); an overview of the whole Devonian (except for the Variscan units located south of the Dinant Synclinorium) was provided by Bultynck \& Dejonghe (2002). The reader is referred to these publications for more details, especially concerning the age of the lithostratigraphic units.

Due to the extreme scarcity of the conodonts in the essentially clastic Lower Devonian succession of southern Belgium, the Lower Devonian stage boundaries have been approximately positioned by Steemans (1989) by means of spores, who indirectly correlated his spore zonation defined in Belgium by way of Brittany (western France) with the chitinozoan zones also recognized in the Lower Devonian succession of Bohemia (see also Godefroid et al. (1994, fig. 2) and Bultynck et al. (2000, fig. 2) for the correlation between the old boundaries and those of the Subcommission on Devonian Stratigraphy). The use of the term 'Pragian' and 'Emsian' in the recent Belgian literature is quite different from the use of the 'Siegenian' and 'Emsian' in the sense of E. Maillieux or E. Asselberghs (see Godefroid et al., 1994, figs 2, 5) and the base of the Emsian in the German sense is older than that defined by Godefroid \& Stainier (1982) in southern Belgium. Furthermore, as pointed out by Carls et al. (2008), the Pragian-Emsian boundary in the current Global Stratotype Section and Point (Zinzilban Gorge section, Uzbekistan; Yolkin et al., 1997) is much older than the Siegenian-Emsian boundary in the German sense. Consequently, as thoroughly explained by Jansen (2016) essentially for the Lower Devonian of the Rhenish Massif, the regional Gedinnian, Siegenian and Emsian stages are used here (Belgian sense!) because the stages recognized internationally but defined in pelagic facies on the basis of conodonts and graptolites, cannot be applied in southern Belgium with precision. Nevertheless, the age provided by Godefroid et al. (1994) and Bultynck \& Dejonghe (2002) are also indicated, despite the discrepancies reported above.

The age of the Waimes Member (Marteau Formation), which is developed on the south-eastern margin of the Stavelot Massif, and its relationships with the Mondrepuis Formation were discussed by Godefroid \& Cravatte (1999, fig. 5) (see also Bultynck et al., 2000, fig. 2) on the basis of the brachiopod associations. These authors correlated the fossiliferous beds of the Waimes Member with their upper Ruisseau des Roches brachiopod fauna defined at Muno and assigned an earliest Gedinnian age (Pridolian) to them (see also Jansen's (2016) discussion).

\section{Material and methods}

The bulk of the material is deposited at the Royal Belgian Institute of Natural Sciences (prefixed RBINS); the present catalogue benefited from the work of J. Godefroid, who patiently gathered the type specimens from all the Palaeozoic invertebrate collections of the RBINS during his career. Some type specimens from the palaeontological collections of the Liège University (prefixed ULg.PA.) are also illustrated.

The Silurian and Devonian species are described herein order by order, following the classification of Williams et al. (1996), and alphabetically classified by their specific name using their original generic assignment, and thus not stratigraphically classified. The names published with a diacritic mark have been corrected according the Article 32.5.2 of the International Code of Zoological Nomenclature (fourth edition, 1999). For each species, a synonymy list, which is focused essentially on the most important Belgian references, is provided in order to facilitate the future revision of the species if necessary. The type locality of a nominal species-group taxon is that of the name-bearing type (Article 76 of the Code); in order to protect the outcrops from unauthorized collecting and vandalism, precise locality information is voluntarily excluded from the present paper but is deposited with the studied material and available to qualified personnel. The localities cited in the text are plotted in Fig. 1. Concerning the syntypes (thus the paralectotypes if a lectotype was previously selected) curated at the
RBINS, only the specimens illustrated in the original papers have been considered, but it is evident that others should be regarded as such. Nonetheless, the screening of the whole RBINS collections for the search of additional syntypes would have been a too timeconsuming task for all the species discussed in this paper, and thus remains to be done.

It clearly appears that many species were erected on the basis of insufficiently preserved material or are only known by a very restricted material (sometimes only one specimen is available!). Had these species not been given a name, the present writer would have left them in open nomenclature.

The smallest specimens were photographed using a lowvacuum scanning electron microscope (ESEM FEI Quanta 200), but not coated with gold. The larger specimens were coated with ammonium chloride sublimate before being photographed.

In the legends of the figures, the original (old) names are followed by current names given in square brackets.

\section{Brachiopods curated at the RBINS}

\subsection{Order Lingulida}

Discina (Discina) forrierensis Maillieux, 1910a

(Fig. 2A-Q)

1910a Discina (Discina) forrierensis Maillieux: 345, 348-349. 1922a Orbiculoidea forrierensis; Maillieux: 13.

1932 Roemerella forrierensis (Maillieux); Maillieux: 11, 22, pl. 1, figs 3-13.

1933 Roemerella forrierensis; Maillieux: 59.

1941a Roemerella forrierensis (Maillieux); Maillieux: 10, 14. 1941b Roemerella forrierensis (Maillieux); Maillieux: 2.

1946 Roemerella forrierensis (Maillieux); Asselberghs: 247, 330.

Type material. No type specimen was selected by Maillieux (1910a), who failed to provide illustrations of his new species. Two holotypes (RBINS a946, a951), one for dorsal valve and one for ventral valve, were designated as such by Maillieux (1932) among the syntypes in contrast with the Article 73.1 of the Code. The dorsal valve RBINS a946 (Maillieux, 1932, pl. 1, fig. 3, 3a, 4) is hereby designated as the lectotype (Fig. 2A-D); the paralectotypes RBINS a947-a955 (Maillieux, 1932, pl. 1, figs 5-13) are re-illustrated here (Fig. 2E-Q).

Type locality and horizon. Rochefort 8650 (see Maillieux, 1910a, 1932), top of the Chooz Formation (Emsian).

Description. See Maillieux (1910a, 1932).

Remarks. The strongly convexoconcave profile of this species led Maillieux (1932) to assign it to Roemerella Hall \& Clarke, 1890 rather than to Orbiculoidea d'Orbigny, 1847 that includes strongly dorsibiconvex shells. Although Mergl (2006) considered the first genus as poorly known and possibly synonym of the latter, Maillieux's (1932, 1941a, 1941b) generic identification is maintained here, pending further investigation. Note that Maillieux (1910a, 1932) discussed the differences between R. forrierensis and the large-sized Gigadiscina anomala (Kayser, 1892) (see Mergl \& Massa, 2005, fig. 1F) from the Siegenian of the Siegen area (Germany).

Current name. Roemerella forrierensis (Maillieux, 1910a).

\subsection{Order Strophomenida}

Stropheodonta (Leptostrophia) calcarifera Maillieux, 1938 (Fig. 2R-S)

1938 Stropheodonta (Leptostrophia) calcarifera Maillieux: 11 (cited as $S$. (L.) calcar [sic]), 35, pl. 1, fig. 3. 1941b Leptostrophia calcarifera Maillieux; Maillieux: 5. 189.

?1955 Leptostrophia calcarifera (Maillieux); Asselberghs: 187,

1973 Stropheodonta (Leptostrophia) calcarifera Maillieux, 1938; García-Alcalde: 48.

1978a Stropheodonta (Leptostrophia) calcarifera Maillieux, 1938; Harper \& Boucot: 73.

Type material. The mould of a ventral valve (RBINS a1116; Fig. 2R-S) was selected as the holotype by Maillieux (1938, pl. 1, fig. 3). 


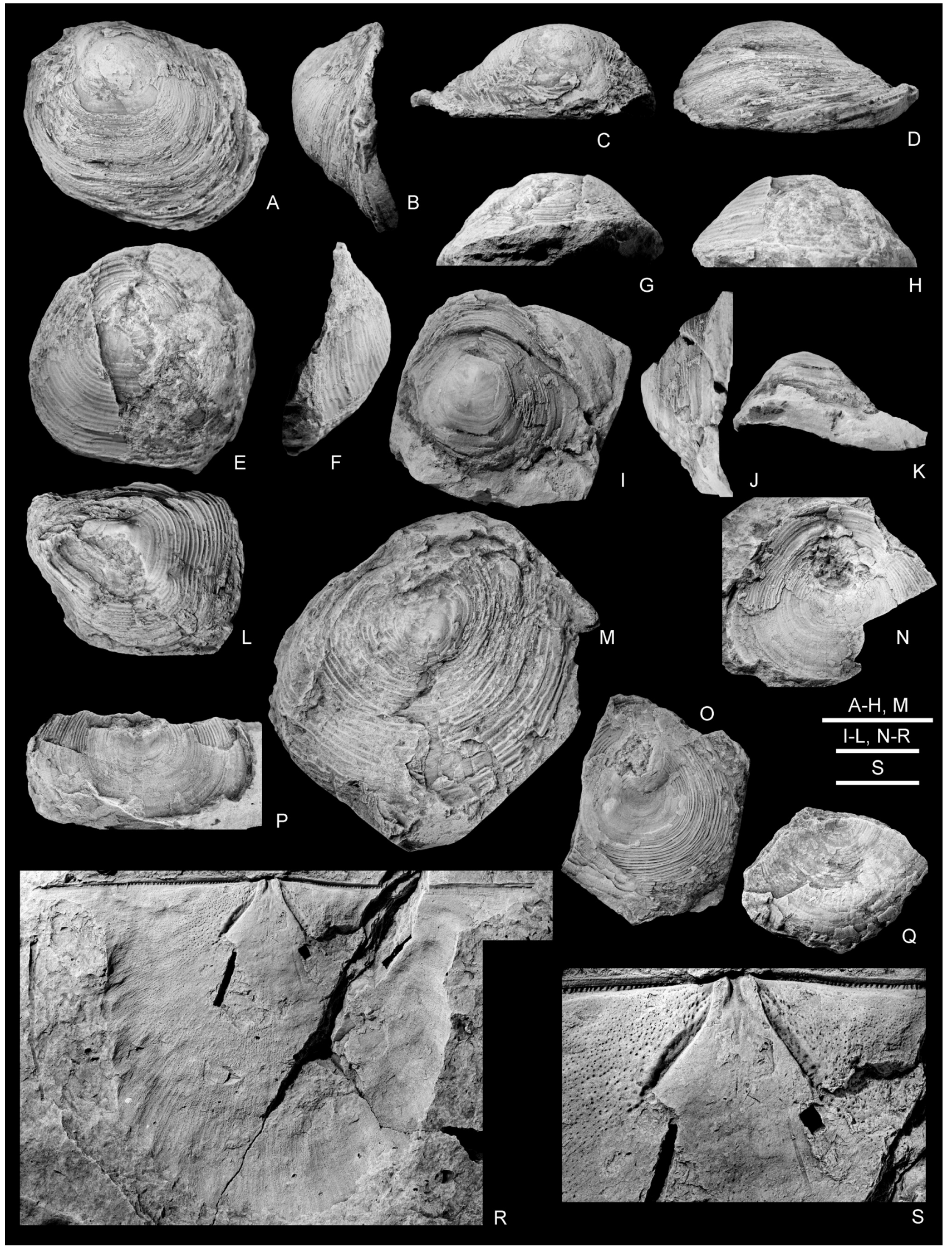

Figure 2. A-Q. Discina (Discina) forrierensis Maillieux, 1910a [Roemerella forrierensis (Maillieux, 1910a)]; Rochefort 8650, Chooz Formation. A-D RBINS a946 (lectotype), dorsal valve in plan, lateral, posterior and anterior views. E-F. RBINS a948 (paralectotype), dorsal valve in plan, lateral, posterior and anterior views. I-K. RBINS a947 (paralectotype), dorsal valve in plan, lateral and anterior views. L. RBINS 949 (paralectotype), dorsal valve in plan view. M. RBINS a950 (paralectotype), dorsal valve in plan view. N. RBINS a951 (paralectotype), ventral valve in plan view. O. RBINS a953 (paralectotype), ventral external mould. P. RBINS a954 (paralectotype), incomplete ventral interior. Q. RBINS a955 (paralectotype), incomplete ventral external mould of ventral valve with shelly remains. BBB. R-S. Stropheodonta (Leptostrophia) calcarifera Maillieux, 1938 ['Leptostrophia' calcarifera (Maillieux, 1938)], RBINS a1116 (holotype), internal mould of ventral valve in plan view and close-up of muscle field; Rochefort 31 (2), Eau Noire Formation. Scale bars: $10 \mathrm{~mm}(\mathrm{~A}-\mathrm{R}), 5 \mathrm{~mm}(\mathrm{~S})$. 
Type locality and horizon. Rochefort 31, Eau Noire Formation (most of this lithostratigraphic unit is late Emsian in age, the top is Eifelian).

Description. See Maillieux (1938).

Remarks. Until now, this species is only represented by the holotype, although Asselberghs (1955) reported its presence in the Eifelian Jemelle Formation on the southeast border of the Dinant Synclinorium, but without illustration. According to GarcíaAlcalde (1973), it is close to representatives of Gampholosia Stainbrook, 1945 by its resupinate profile, the structure of its ventral muscle field and its parvicostellate ornamentation (it needs to be confirmed by the study of further material!), but the development of nervation is not revealed. Harper \& Boucot (1978a) suggested that Maillieux's species could belong to a new leptostrophiid genus. According to U. Jansen (pers. com., March 2019), Maillieux's species has typical leptostrophiid muscle field and process cavities; 'Leptostrophia' palma (Kayser, 1871) (hardly developed socket ridges) or Leptostrophiella sera (Fuchs, 1919) (with distinct socket ridges) seem to be more closely related although these do not show a resupinate profile. For the reasons cited above, the generic assignment of the species calcarifera still remains uncertain.

Current name. 'Leptostrophia' calcarifera (Maillieux, 1938).

\section{Stropheodonta couviniensis Asselberghs, 1930}

(Fig. 3A-L)

1922 Stropheodonta triculta Fuchs; Asselberghs: B133.

1923 Stropheodonta triculta Fuchs; Asselberghs: 19-20, 63, table 1, pl. 1, figs 1a-b, 2-3.

1930 Stropheodonta couviniensis Asselberghs: 29.

1933 Stropheodonta couviniensis; Maillieux: 67, pl. 4, fig. 82. 1938 Stropheodonta couviniensis Asselberghs; Maillieux: 11. 1941b Stropheodonta couviniensis Asselberghs; Maillieux: 5. 1977 Bojodouvillina couviniensis (E. Asselberghs, 1930); Bultynck \& Boonen: 491-492.

1978b Stropheodonta couviniensis Asselberghs, 1930; Harper \& Boucot: 45.

1981 Stropheodonta couviniensis Asselberghs; Jahnke: 157

Type material. The ventral internal mould (RBINS a3146; Fig. 3A-E) illustrated by Asselberghs (1923, pl. 1, fig. 1a-b) is hereby designated as the lectotype whereas the two other ventral internal moulds (RBINS a3147-a3148; Fig. 3F-H, I-L) illustrated by Asselberghs (1923, pl. 1, figs 2-3) are paralectotypes.

Type locality and horizon. Bioul (Godinne), flanks of the Godinne anticlinal, Rivière Formation, Rouillon Member (Eifelian).

Description. See Asselberghs (1923).

Remarks. Stropheodonta couviniensis was considered as a synonym of Strophomena taeniolata Sandberger \& Sandberger, 1856 by Jahnke (1981); the latter was selected by Jansen (2014) as the type species of his new genus Gibbodouvillina. However, the available ventral valves are clearly less convex than those of $G$. taeniolata as figured by Jansen (2014, figs 5A, E-F) or than those of G. interstrialis (Philips, 1841) (e.g. Biernat, 1966; Halamski, 2009). In point of fact, the morphology of the species couviniensis, both externally and internally, suggests an assignment to the flat-shelled genus Mesodouvillina Williams, 1950 , but the examination of dorsal valves is required to confirm the generic identification and the complete reassessment of Asselberghs' species. 1930).

Current name. Mesodouvillina? couviniensis (Asselberghs,

Pholidostrophia extensa Maillieux, 1938

(Figs 3M-BB, 4A-C)

1938 Pholidostrophia extensa Maillieux: 21, 36, pl. 1, figs 4-6. 1941b Pholidostrophia extensa Maillieux; Maillieux: 6.

1967 P. [Pholidostrophia] extensa Maillieux; Harper et al.: 417.

Type material. Maillieux (1938) illustrated three specimens that he considered as the types of his new species. Nevertheless, he did not select a holotype among them. The articulated specimen RBINS a1119 (Maillieux, 1938, pl. 1, fig. 6), the better preserved one in terms of ornamentation, is hereby designated as the lectotype (Figs $3 \mathrm{~W}-\mathrm{BB}, 4 \mathrm{~A}-\mathrm{C}$ ); the two other specimens RBINS a1117-a1118 (Maillieux, 1938, pl. 1, figs 4, 5) are thus paralectotypes (Fig. 3M-Q, R-V).

Type locality and horizon. Olloy 7970, Jemelle Formation (Eifelian).

Description. See Maillieux (1938).

Remarks. Harper et al. (1967) questionably assigned this species to Mesopholidostrophia Williams, 1950, which was considered by these authors as a subgenus of Pholidostrophia Hall \& Clarke, 1892. Nevertheless, none of the types displays the internal morphology that is crucial for generic identification. On the basis of the external morphology, it is not at all excluded that Maillieux's species is a synonym of Pholidostrophia (Mesopholidostrophia) semicircularis (Kayser, 1871) from the Eifelian of the Eifel as re-illustrated by Harper et al. (1967, textfigs 4-8).

Current name. Pholidostrophia extensa Maillieux, 1938.

\subsection{Order Productida}

\subsubsection{Suborder Chonetidina}

Anoplia theorassensis Maillieux, 1941a

(Fig. 4D-I)

1941a Anoplia theorassensis Maillieux: 34-36, figs 2, 3, 4. 1941b Anoplia theorassensis Maillieux; Maillieux: 8. 1941c Anoplia theorassensis Maillieux; Maillieux: 7.

1946 Anoplia theorassensis Maillieux; Asselberghs: 268, 331. 1962 Anoplia theorassensis Maillieux, 1941; Muir-Wood: 53, 54, fig. 10c (copy of Maillieux, 1941a, fig. 2).

1968 Anoplia theorassensis Maillieux, 1941; Boucot \& Harper: 168.

1981 Anoplia theorassensis Maillieux; Rachebœuf: 269, 273. 1988 Anoplia theorassensis Maillieux, 1941; Godefroid \& Stainier: 111, 139.

1994 Anoplia theorassensis Maillieux, 1941; Godefroid in Godefroid et al.: 16, fig. 10.

1995 Anoplia theorassensis Maillieux, 1941; Rachebœuf: 225. 2016 Anoplia theorassensis Maillieux, 1941; Jansen: 86.

Type material. The ventral internal mould RBINS a7779 (Maillieux, 1941a, figs 2, 4?) is designated hereby as the lectotype (Fig. 4D-F) whereas the dorsal internal mould RBINS a7780 (Maillieux, 1941a, fig. 3) (Fig. 4G-I) is a paralectotype. Both specimens are located on the same slab including six additional internal moulds of ventral valves that are not illustrated here, but they have to be considered as additional paralectotypes according to the Article 74.1.3 of the Code.

Type locality and horizon. Couvin 8711, Hierges Formation (late Emsian).

Description. See Maillieux (1941a).

Remarks. This minute chonetidine ranks among the most abundant brachiopods of the Hierges Formation in Belgium and northern France. It is also reported in the Wiltz Formation (Eifel Synclines, Germany) by Jansen (2016), but its presence in the Lower Devonian of Portugal (Perdigão, 1973) needs to be confirmed (see Rachebœuf, 1981).

Current name. Anoplia theorassensis Maillieux, 1941a.

\subsubsection{Suborder Productidina}

Productus (Thomasina) demaneti Maillieux, 1938 (Fig. 4J-O)

1938 Productus (Thomasina) demaneti Maillieux: 21, 37, pl. 1, fig. 9, 9a-c.

1941b Thomasina demaneti Maillieux; Maillieux: 7.

1980 Eopr. [Eoproductella] demaneti (Maillieux, 1938);

Rzhonsnitskaya: 60, 61.

1983 Eoproductella demaneti; Rzhonsnitskaya: 9, table 1.

1990 Productus (Thomasina) demaneti Maillieux, 1938; Lazarev: 49. 


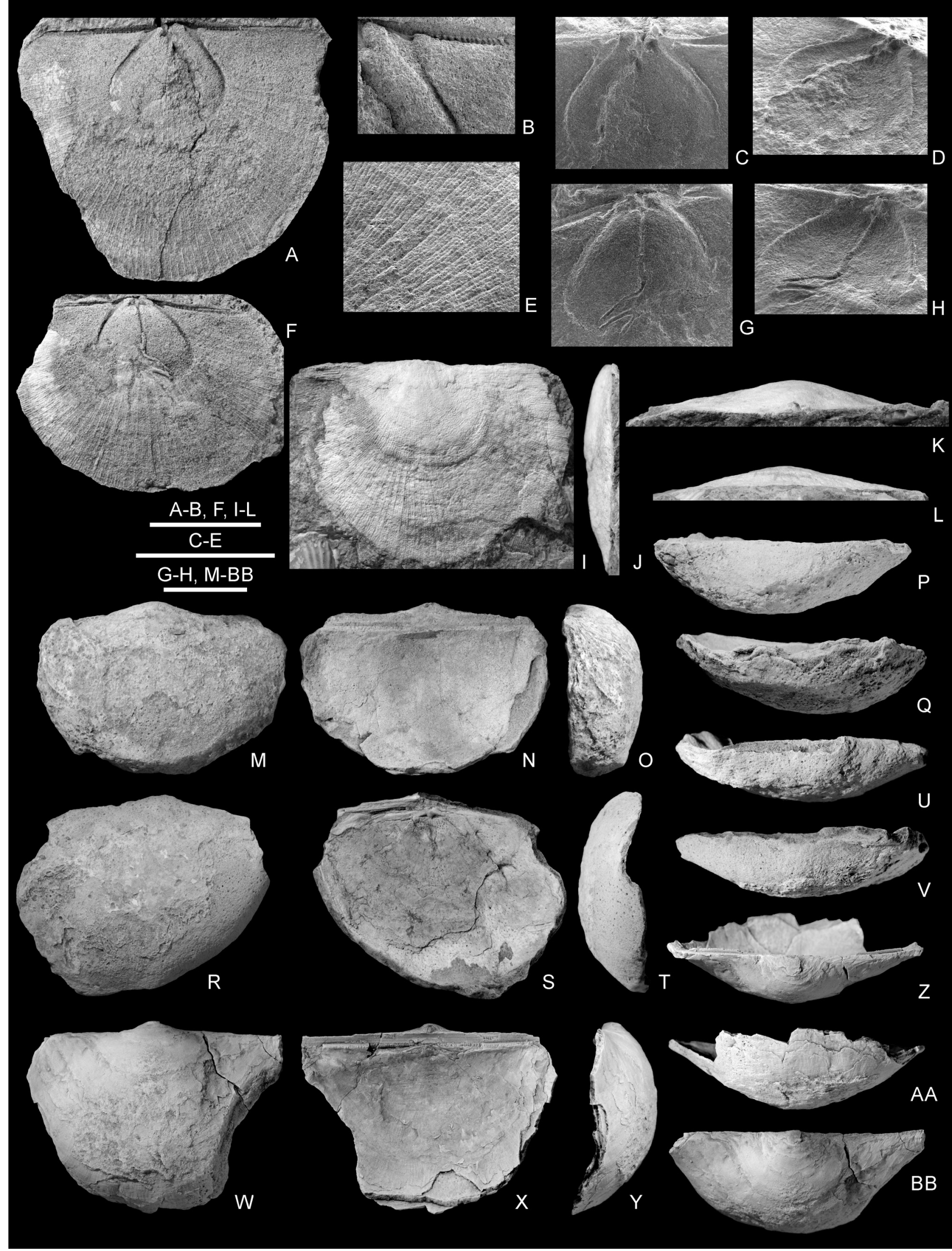

Figure 3. A-L. Stropheodonta couviniensis Asselberghs, 1930 [Mesodouvillina? couviniensis (Asselberghs, 1930)]; Godinne (flanks of the Godinne anticline), Rivière Formation. A-E. RBINS a3146 (lectotype), internal mould of a ventral valve in plan view, close-up of denticulate hinge line, cast of muscle field, oblique anterolateral view of cast of muscle field, detail of external mould. F-H. RBINS a3147 (paralectotype), internal mould of a ventral valve in plan view, cast of muscle field, oblique anterolateral view of cast of muscle field. I-L. RBINS a3148 (paralectotype), exfoliated ventral valve in ventral, lateral, posterior and anterior views. M-BB. Pholidostrophia extensa Maillieux, 1938; Olloy 7970, Jemelle Formation. M-Q. RBINS a1117 (paralectotype), articulated specimen in ventral, dorsal, lateral, posterior and anterior views. R-V. RBINS a1118 (paralectotype), articulated specimen in ventral, dorsal, lateral, posterior and anterior views. W-BB. RBINS a1119 (lectotype), articulated specimen (removed from the matrix) in ventral, dorsal, lateral, posterior, anterior and posteroventral views (see also Fig. 4A-C). Scale bars: $10 \mathrm{~mm}$ (A, C-D, F, I-L, M-BB), 5 mm (B, E, G-H). 


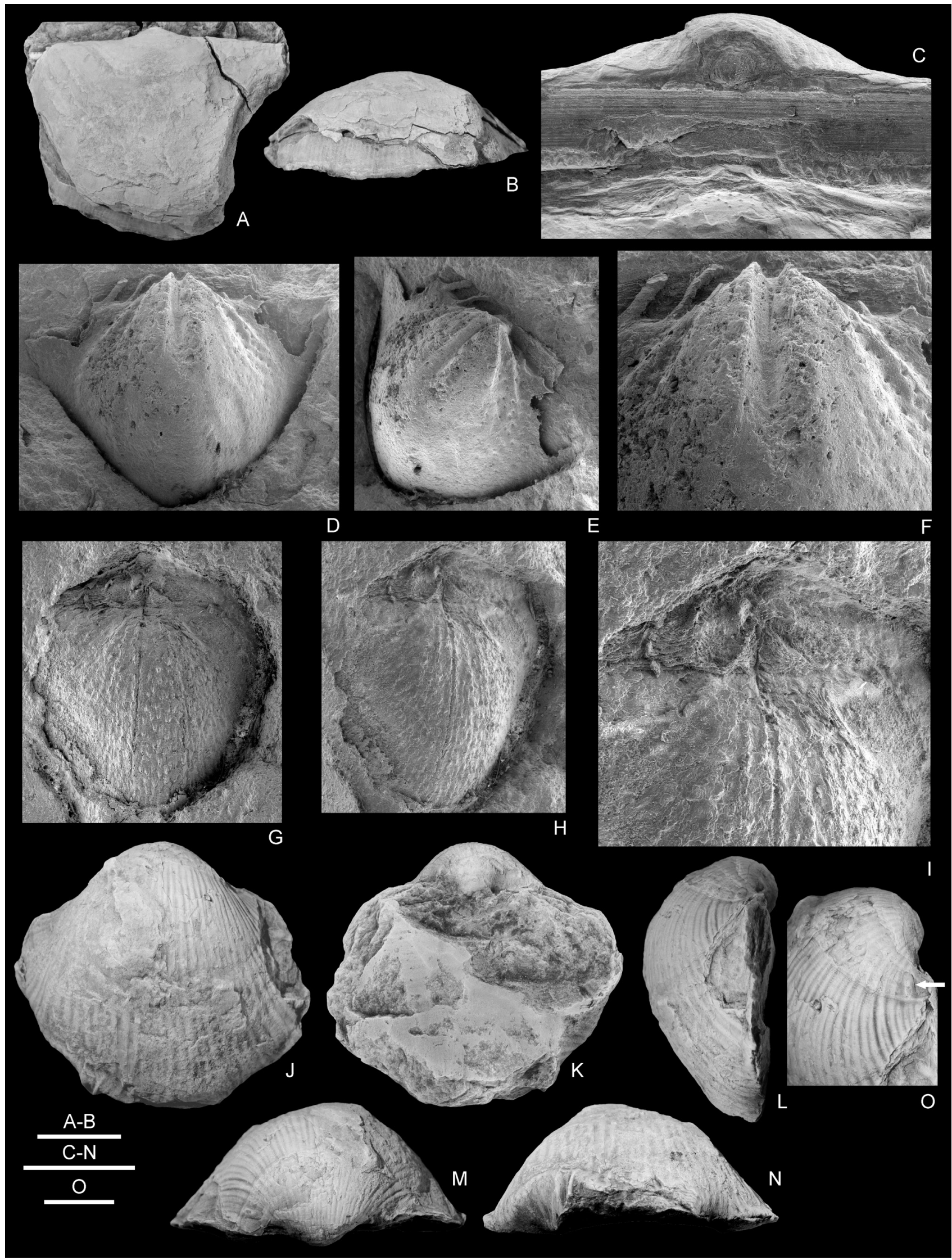

Figure 4. A-C. Pholidostrophia extensa Maillieux, 1938, RBINS a1119 (lectotype), articulated specimen in ventral and anterior (ventral valve on top; enclosed in matrix as illustrated by Maillieux (1938)) views and close-up of the interareas (see also Fig. 3W-BB); Olloy 7970, Jemelle Formation. D-I. Anoplia theorassensis Maillieux, 1941a; Couvin 8711, Hierges Formation; all SEM. D-F. RBINS a7779 (lectotype), internal mould of ventral valve in plan and oblique posterolateral views, and detail of umbonal region. G-I. RBINS a7780 (paralectotype), interior of dorsal valve (with shelly remains) in plan and oblique lateral views, and detail of the cardinalia. J-O. Productus (Thomasina) demaneti Maillieux, 1938 ['Productina'demaneti (Maillieux, 1938)], RBINS a1120 (holotype), articulated specimen with dorsal valve covered by carbonate matrix in ventral, dorsal, lateral, posterior and anterior views (ventral valve on top for M and N), and detail of ornamentation and flank spine (arrow); Rochefort 7273, Jemelle Formation. Scale bars: 10 mm (A-B, J-N), 1 mm (C-E, G-H), 0.5 mm (F, I), 5 mm (O). 
Type material. The holotype (RBINS a1120; Fig. 4J-O), selected by Maillieux (1938, pl. 1, fig. 9, 9a-c), corresponds to an articulated specimen of which the dorsal valve is covered by carbonate matrix.

Type locality and horizon. Rochefort 7273, Jemelle Formation (Eifelian).

Description. See Maillieux (1938).

Remarks. The holotype - the only specimen available - is characterized by flattened ribs increasing by bifurcation and numerous growth lines; only one flank spine base was observed close to the hinge line on the right side of the ventral valve (Fig. 4L-M). Rzhonsnitskaya (1980) included Maillieux's (1938) species, which ranks among the oldest Productidina from southern Belgium, within her new genus Eoproductella, but this generic assignment was rightly challenged by Lazarev (1990) on the basis of its coarser radial ornamentation. Moreover, the disposition of the spines in the type species of Eoproductella is markedly distinct (compare with Rzhonsnitskaya, 1980, pl. 18, figs 1ab, 3-4). The lack of knowledge about the internal morphology precludes a satisfactory generic assignment even if the external morphology is very close to the productellid genera Productina Sutton, 1938 and Argentiproductus Cooper \& Muir-Wood, 1951 as revised by Brunton \& Mundy (1993), which are both clearly younger stratigraphically. Further material is thus needed to reach a better generic identification, but the species demaneti is temporarily referred to Sutton's genus due to its external features.

Current name. 'Productina'demaneti (Maillieux, 1938).

\subsection{Order Orthotetida}

Schuchertellopsis durbutensis Maillieux, 1939

1939 Schuchertellopsis durbutensis Maillieux: 6-8, figs 1-6. 1941b Schuchertellopsis durbutensis Maillieux; Maillieux: 6. 1965 Schuchertellopsis durbutensis; Williams: H408.

1974a Schuchertellopsis durbutensis Maillieux, E., 1939; Sartenaer: 6, 10.

2000 Schuchertellopsis (Schuchertellopsis) durbutensis; Williams \& Brunton: 667, fig. 480.5a-c.

2005 Schuchertellopsis (Schuchertellopsis) durbutensis Maillieux, 1939; Long \& Brunton: cited many times, figs 1a-b, 2, 4, 5-15.

2005a Schuchertellopsis (Schuchertellopsis) durbutensis Maillieux, 1939; Mottequin: 2, 294, 312, 317, pl. 35, fig. 3.

2007 Schuchertellopsis (Schuchertellopsis) durbutensis; Brunton: 2674, 2677, fig. 1782a-b.

2008a Schuchertellopsis (Schuchertellopsis) durbutensis Maillieux, 1939; Mottequin: 1060, 1069, figs 10.1, 23.

Type material. Maillieux (1939) did not select a holotype for his new species and no lectotype was designated by Long \& Brunton (2005), who just mentioned the expression types 1 (RBINS a1140), 2 (RBINS a1142A), and 3 (RBINS a1139). I choose the ventral valve RBINS a1140 (Maillieux, 1939, fig. 2; Long \& Brunton, 2005, fig. 1a-b) as lectotype. The specimens RBINS a1139, 1141A-B, 1142A-B, which were illustrated by Maillieux (1939, figs 1, 3-6) (see also Long \& Brunton, 2005, figs 2, 4), are paralectotypes.

Type locality and horizon. Durbuy 5337, Barvaux Formation (late Frasnian).

Description. See Maillieux (1939) and Long \& Brunton (2005).

Remarks. This particular schuchertellid is one of the numerous epizoans (e.g. tabulate corals, bryozoans, brachiopods) of the cyrtospiriferids occurring in the Barvaux Formation, but it is markedly less abundant than the representatives of the craniide genus Petrocrania Raymond, 1911 (Mottequin, 2005a). The shell was fixed by complete cementation of the ventral valve on its host, but without simulating the morphology of the latter as is the case of Petrocrania, and located close to the anterior margin of the host, either on dorsal or ventral valve (Long \& Brunton, 2005).

Current name. Schuchertellopsis (Schuchertellopsis) durbutensis Maillieux, 1939.
Streptorhynchus rahiri Maillieux, 1909a

(Fig. 5A-Q)

1909a Streptorhynchus Rahiri Maillieux: 119, 142, 148-149, fig. 2a-c.

1912 Orthothetes [sic] Rahiri; Asselberghs: 7.

1912 Orthothetes [sic] Rahiri; Maillieux: 47.

1927 Schuchertella Rahiri Maillieux; Maillieux in Asselberghs \& Maillieux: 160.

1933 Schellwienella Rahiri; Maillieux: 81.

? 1936 Schellwienella Rahiri (Maillieux); Asselberghs: 257, 313, 316.

1939 'Streptorhynchus' Rahiri Maillieux; Maillieux: 8.

1940a Schuchertellopsis Rahiri (Maillieux); Maillieux: 7.

1941b Schuchertellopsis rahiri (Maillieux); Maillieux: 6.

1988 Streptorhynchus rahiri; Brice: 341.

Type material. The articulated specimen RBINS a1670 (Maillieux, 1909a, fig. 2a) is hereby designated as the lectotype (Fig. 5A-E); the paralectotypes are the specimens RBINS a16711672 (Maillieux, 1909a, fig. 2b, c) (Fig. 5F-L, M-Q) and a fourth poorly preserved one (RBINS a1673), which was not illustrated by Maillieux (1909a).

Type locality and horizon. Couvin 8705, Nismes Formation (early Frasnian). Except its Givetian lowermost part, the Nismes Formation is early Frasnian in age (e.g. Bultynck \& Dejonghe, 2002).

Description. See Maillieux (1909a).

Remarks. The investigation of the available material did not reveal the development of extropunctae. From the generic viewpoint, this species, which was considered as scarce by Maillieux (1909a), is doubtfully referred to the areostrophiid genus Floweria Cooper \& Dutro, 1982 rather than to the related genus Eoschuchertella Gratsianova, 1974 on the basis of its aequibiconvex shell with ribs increasing by intercalation. At the ventral valve, the muscle field is poorly impressed (Fig. 5F) whereas the pseudodeltidium is strongly convex, complemented at the dorsal valve, by a large, medianly grooved chilidium (Fig. 5K-L). According to Brice (1988), Maillieux's species is very close to Eoschuchertella bouchardi (Rigaux, 1873) and would only differ from the latter by the absence of a shallow median depression on the dorsal valve. Nonetheless, the revision of both species is needed.

Current name. Floweria? rahiri (Maillieux, 1909a).

\subsection{Orthida}

Fascicostella belgica Maillieux, 1941a

(Fig. 5R-V)

1941a Fascicostella belgica Maillieux: 10, 17-18, fig. 1, 1a. 1941b Fascicostella belgica Maillieux; Maillieux: 3.

1946 Fascicostella belgica Maillieux; Asselberghs: 267, 330.

1971 Fascicostella belgica Maillieux, 1941; Walmsley \& Boucot: 522-523.

1994 Fascicostella belgica Maillieux, 1941; Godefroid in Godefroid et al.: 16, fig. 10.

Type material. According to Maillieux (1941a), only an incomplete dorsal internal mould (RBINS a7778; Fig. 5R-V) was available for study; it is thus the holotype by monotypy.

Type locality and horizon. Couvin 8711, Hierges Formation (late Emsian).

Description. See Maillieux (1941a).

Remarks. According to Walmsley \& Boucot (1971), Maillieux's species needs further study before assignment to Fascicostella Schuchert \& Cooper, 1931 due to its poor original illustration. On the basis of the holotype, it is obvious that this species cannot be referred to that genus as there is no sign of fasciculation at all. Such a type of ornamentation should have left traces on the internal mould. The internal morphology of the holotype is consistent with the concept of the genus Resserella Bancroft, 1928 (U. Jansen, pers. com., March 2019) and strongly resembles that of the Emsian species Resserella triangularis (Zeiler, 1857) from Germany illustrated by Maurer (1889, pl. 3, figs 8-12) and Walmsley \& Boucot (1971, pl. 101, figs 1-2). More 


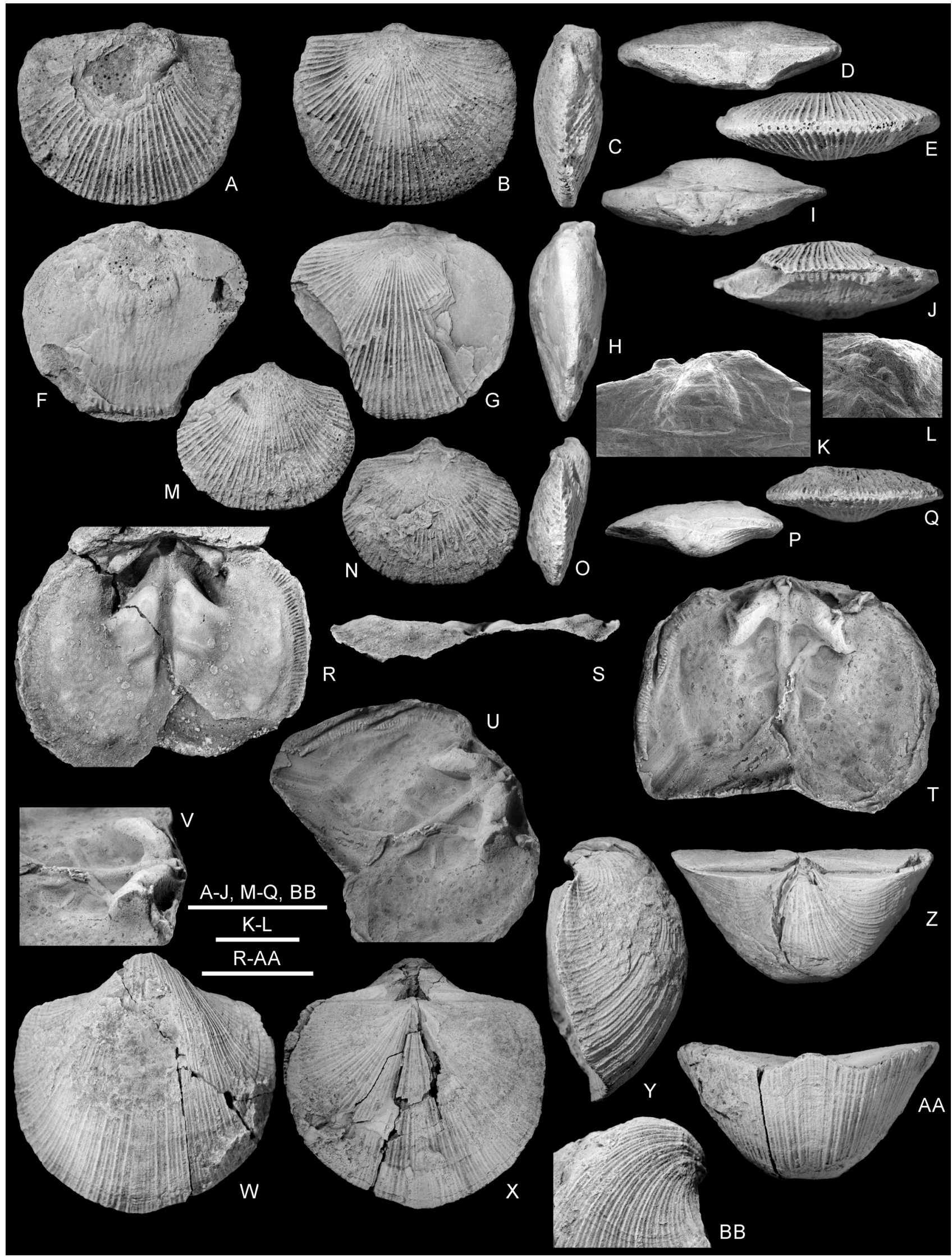

Figure 5. A-Q. Streptorhynchus rahiri Maillieux, 1909a [Floweria? rahiri (Maillieux, 1909a)]; Couvin 8705, Nismes Formation. A-E. RBINS a1670 (lectotype), articulated specimen in ventral, dorsal, lateral, posterior and anterior views. F-L. RBINS a1671 (paralectotype), articulated specimen in ventral, dorsal, lateral, posterior and anterior views, and close-up (SEM) of central part of ventral interarea (pseudodeltidium, chilidium). M-Q. RBINS a1672 (paralectotype), articulated juvenile specimen in ventral, dorsal, lateral, posterior and anterior views. R-V. Fascicostella belgica Maillieux, 1941a [Resserella belgica (Maillieux, 1941a)], RBINS a7778 (holotype), internal mould of dorsal valve in plan and anterior views, putty cast in plan, oblique anterolateral views, and lateral view of the cardinalia; Couvin 8711, Hierges Formation. W-BB. Orthis dorsoplicata Béclard, 1891 [Parmorthina? dorsoplicata (Béclard, 1891)], RBINS a1696, articulated specimen in ventral, dorsal, lateral, posterior and anterior views, and detail of the ornamentation on the right side of the ventral umbo; Grupont (Bure), Eau Noire Formation. Scale bars: $10 \mathrm{~mm}$ (A-J, M-Q, R-AA, BB), $2.5 \mathrm{~mm}$ (K-L). 
specimens are required to reach a better species characterization and to discuss its relationships with $R$. triangularis.

Current name. Resserella belgica (Maillieux, 1941a).

Orthis dorsoplicata Béclard, 1891

(Fig. 5W-BB)

1891 Orthis dorsoplicata Béclard: 99-100, pl. 3, figs 6-8. 1922a Rhipidomella dorsoplicata; Maillieux: 14.

1932 Orthis [Fascicostella] dorsoplicata Béclard; Schuchert

\& Cooper: 130 .

1933 Fascicostella dorsoplicata; Maillieux: 66

1938 Fascicostella dorsoplicata (Béclard); Maillieux: 11.

1941a Fascicostella dorsoplicata (Béclard); Maillieux: 17.

1941b Fascicostella dorsoplicata (Béclard); Maillieux: 3.

1971 Orthis dorsoplicata Béclard; Walmsley \& Boucot: 522523.

1975 Orthis dorsoplicata Béclard, 1891; Drot: 12.

2015 Orthis dorsoplicata Béclard, 1891; García-Alcalde: 66.

Type material. Of the three specimens illustrated by Béclard (1891), only the largest (RBINS a1696) was traced (Béclard, 1891, pl. 3, fig. 8, 8a-d) and is the lectotype (Fig. 5W-BB) by present designation.

Type locality and horizon. Grupont (Bure), Eau Noire Formation (late Emsian-Eifelian).

Description. See Béclard (1891).

Remarks. The species seems to be rare according to the few poorly preserved specimens present in the RBINS collections. Béclard (1891) cited his new species in Lesterny and Bure where it was associated to Rhynchonella parvula Béclard, 1891 (non R. parvula Eudes-Deslongchamps, 1862) and Terebratula loxogonia Béclard, 1891 (see below for remarks related to these two species). Schuchert \& Cooper (1932) assigned Orthis dorsoplicata to the genus Fascicostella Schuchert \& Cooper, 1931, an opinion followed by Maillieux (1938, 1941a, 1941b), but this assignment was rightly questioned by Walmsley \& Boucot (1971) because its ornamentation is not as coarsely fascicostellate as in Fascicostella. The main external features of the lectotype are the following: shell strongly planoconvex, median ventral flattening, ventral interarea concave and apsacline, dorsal sulcus with raised median area, dorsal interarea as half as long as ventral one, plane catacline, and ornamentation finely fascicostellate. The lack of data related to the internal morphology precludes a definite generic assignment, but the type of ornamentation consisting of angular costellae arranged in poor bundles with strongly accentuated primary costellae may suggest an assignment to the dalmanellid Parmorthina Havlíček, 1975.

Current name. Parmorthina? dorsoplicata (Béclard, 1891).

Orthis musischura Béclard, 1891

(Figs 6A-X, 7A-C)

1891 Orthis musischura Béclard: 101-102, pl. 4, figs 1-6.

1904 Orthis musischura Béclard, 1892 [sic]; Drevermann: 264.

1910b Orthis musischura Béclard; Maillieux: 194.

1911 Orthis musischura Béclard; Maillieux: 178.

1912a Orthis musischura Béclard; Leriche: 26, 27.

1931 Orthis musischura Béclard; Maillieux: 11.

Type material. The articulated internal mould (RBINS a1699; Fig. 6A-F) illustrated by Béclard (1891, pl. 4, figs 3, 5) is hereby designated as the lectotype. The paralectotypes correspond to the dorsal internal mould RBINS a1701 (Béclard, 1891, pl. 4, fig. 6) (Fig. 6G-J), the ventral internal moulds RBINS a1698 (Béclard, 1891, pl. 4, fig. 2) (Fig. 6K-M) and RBINS a1700 (Béclard, 1891, pl. 4, fig. 4) (Fig. 6N-P), and the dorsal valve RBINS a1702 (Béclard, 1891, pl. 4, fig. 1f) (Fig. 6Q-X). The articulated internal mould RBINS a1697 (Béclard, 1891, pl. 4, fig. 1, 1a-e) has not been traced; only the artificial cast of the dorsal valve was recovered (Fig. 7A-C).

Type locality and horizon. Saint-Hubert 3 (23), Villé Formation (Siegenian; Pragian).

Description. See Béclard (1891).
Remarks. Drevermann (1904) and Maillieux (1910b, 1911, 1931) regarded Béclard's species as a synonym of Proschizophoria personata (Zeiler, 1857), the type species of the proschizophoriid genus Proschizophoria Maillieux, 1911 (see Boucot et al., 1966. Carls, 1974), which is common in the Siegenian of southern Belgium (Godefroid in Godefroid et al., 1994, fig. 10). Carls (1974) discussed some of the proschizophoriids recognized in Belgium and transferred the specimens previously identified as Proschizophoria torifera (Fuchs, 1919) by Asselberghs (1930) and Boucot (1960) to Fulcriphoria cf. havliceki Carls, 1974 whereas the dorsal valve illustrated by Maillieux (1931, pl. 1, fig. 1) as $P$. personata, which was rejected by Boucot et al. (1966) from Maillieux's genus, was doubtfully referred to Fulcriphoria sp. T as well as the material illustrated by Renouf (1972, text-figs 6A, 7A). Re-examination of the Devonian representatives of this family in Belgium and northern France is badly needed.

Current name. Proschizophoria personata (Zeiler, 1857).

\subsection{Order Pentamerida}

Pentamerus broecki Maillieux, 1909b

(Fig. 7D-H)

1909b Pentamerus Broecki Maillieux: 232, fig. 4a-c.

1974 Neometabolipa broecki (Maillieux, E., 1909); Godefroid: 35-41, table 5, text-figs 11, 16, pl. 7, figs 3-5 (see this author for a more complete synonymy).

1999 Neometabolipa broecki; Godefroid \& Sartenaer in Boulvain et al.: 19, fig. BIO4.

Type material. The articulated specimen RBINS a223 (Maillieux, 1909b, fig. 4a-c) was selected as the lectotype by Godefroid (1974, pl. 7, fig. 5a-e); it is re-illustrated in Fig. 7DH.

Type horizon and age. Couvin 8174 (45), Grands Breux Formation, Lion Member (middle Frasnian).

Description. See Maillieux (1909b) and Godefroid (1974).

Remarks. Maillieux's species was assigned by Godefroid (1974) to his new genus Neometabolipa (see remarks concerning Pentamerus greindli).

Current name. Neometabolipa broecki (Maillieux, 1909b).

Pentamerus greindli Maillieux, 1909b

(Fig. 7I-N)

1909b Pentamerus Greindli Maillieux: 230, fig. 3a-c.

1974 Metabolipa greindli (Maillieux, E., 1909); Godefroid: 7-23, tables 1-2, text-figs 3-7, 16, pl. 1, figs 1-7, pl. 2, figs 1-6, pl. 3, figs 1-6, pl. 4, figs 1-5, pl. 5, figs 1, 2 (see this author for a more complete synonymy).

1983 Metabolipa greindli; Godefroid in Robaszynski \& Dupuis: pl. 1, fig. 6.

1999 Metabolipa greindli; Godefroid \& Sartenaer in Boulvain et al.: 19, fig. BIO4.

Type material. The articulated specimen RBINS a222 (Maillieux, 1909b, text-fig. 3a-c) was selected as the lectotype by Godefroid (1974, pl. 3, fig. 1a-e) and is re-illustrated here in Fig. 7I-N. The paralectotypes include the specimens RBINS a224-226 (Godefroid, 1974).

Type locality and horizon. Couvin 6149 (38), Moulin Liénaux Formation, Arche Member (middle Frasnian).

Description. See Maillieux (1909b) and Godefroid (1974).

Remarks. This species was selected by Godefroid (1974) as the type species of his new genus Metabolipa and fully redescribed. Note that Blodgett et al. (2002) considered Metabolipa and Neometabolipa as synonyms of Gypidula Hall, 1867 but the distinctive characters stated by Godefroid (1974) and specified later (Godefroid, 1979) appear to Mottequin (2008b) sufficient to distinguish Hall's genus from Metabolipa and Neometabolipa. Current name. Metabolipa greindli (Maillieux, 1909b). 


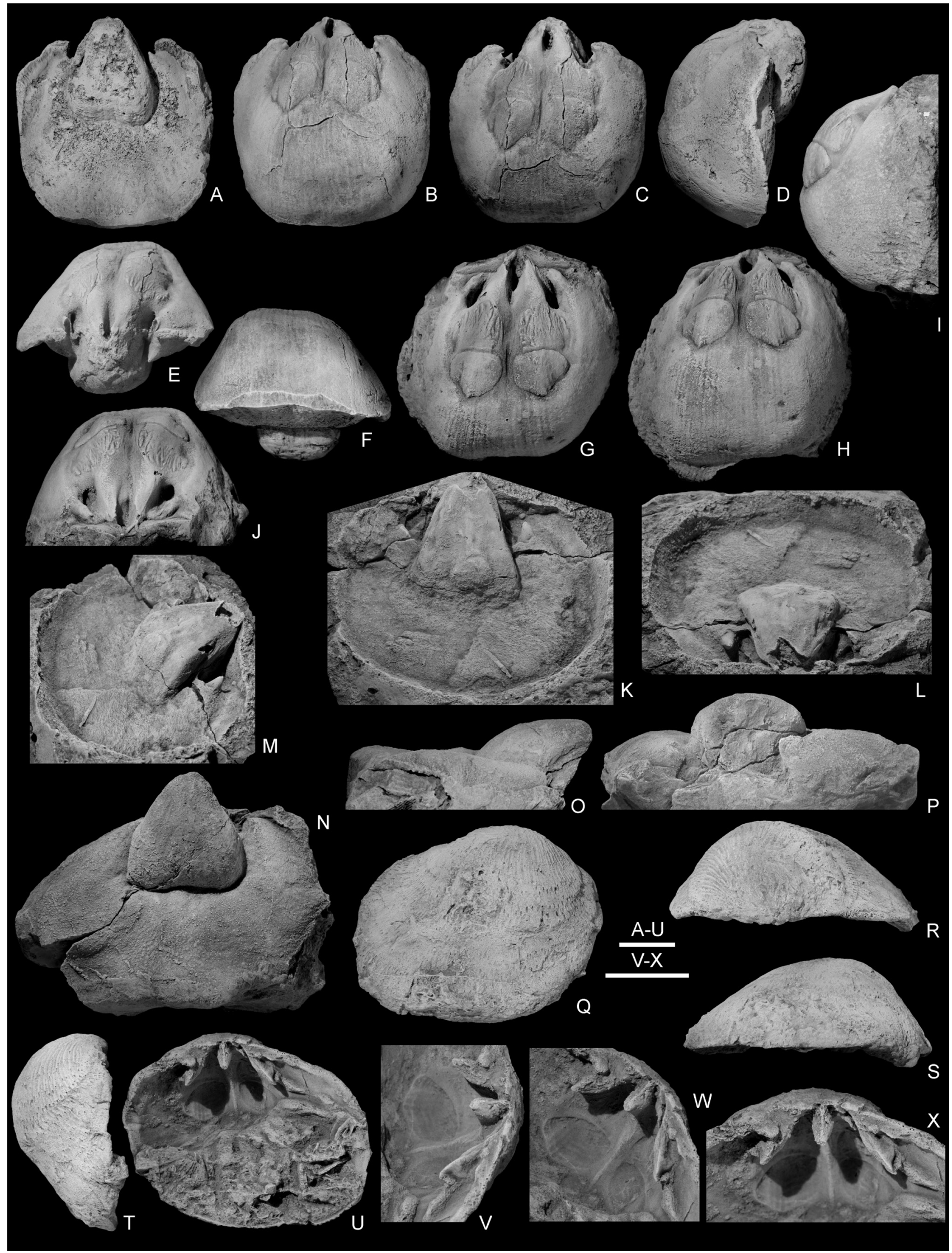

Figure 6. Orthis musischura Béclard, 1891 [Proschizophoria personata (Zeiler, 1857)]; Saint-Hubert 3 (23), Villé Formation (A-M, Q-X); Nouzonville, Villé Formation (N-P). A-F. RBINS a1699 (lectotype), internal mould of an articulated specimen in ventral, dorsal, posterodorsal, lateral, posterior and anterior views. G-J. RBINS a1701 (paralectotype), internal mould of a dorsal valve in posterodorsal, plan, lateral and posterior views. K-M. RBINS a1698 (paralectotype), internal mould of ventral valve in plan, posteroventral and oblique lateral views. N-P. RBINS a1700 (paralectotype), internal mould of ventral valve in plan, lateral and posterior views. Q-X. RBINS a1702 (paralectotype), deformed dorsal valve in external, posterior, anterior, lateral and internal views, and close-up of cardinalia (V-X). Scale bars are all $10 \mathrm{~mm}$. 


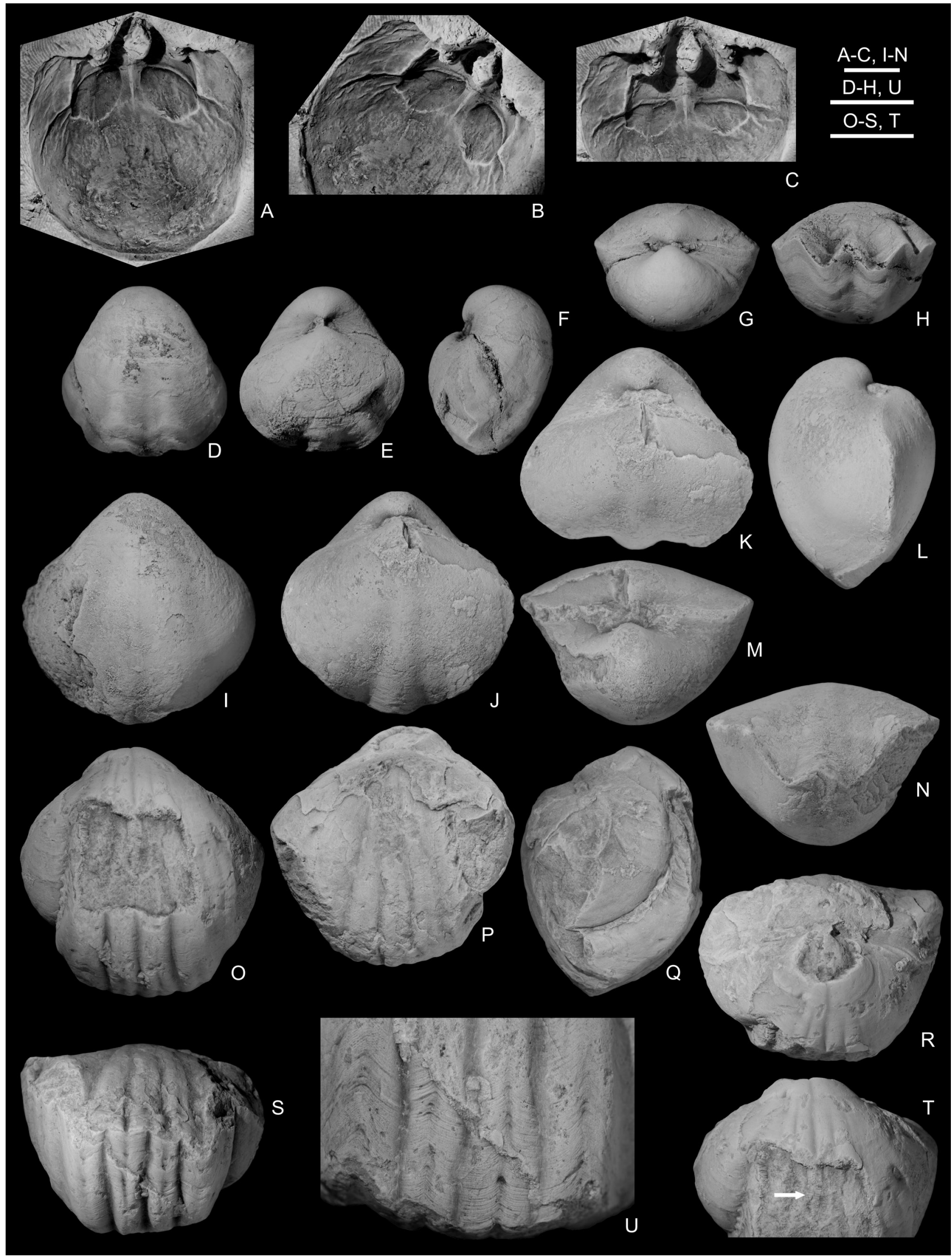

Figure 7. A-C. Orthis musischura Béclard, 1891 [Proschizophoria personata (Zeiler, 1857)], RBINS a1697, putty cast of dorsal interior in plan, oblique lateral and inclined plan (muscle field and cardinalia) views; Saint-Hubert 3 (23), Villé Formation. D-H. Pentamerus broecki Maillieux, 1909b [Neometabolipa broecki (Maillieux, 1909b)], RBINS a223 (lectotype), articulated specimen in ventral, dorsal, lateral, posterior and anterior views; Couvin 8174 (45), Grands Breux Formation (Lion Member). I-N. Pentamerus greindli Maillieux, 1909b [Metabolipa greindli (Maillieux, 1909b)], RBINS a222 (lectotype), articulated specimen in ventral, dorsal, posterodorsal, lateral, posterior and anterior views; Couvin 6149 (38), Moulin Liénaux Formation (Arche Member). O-U. Pentamerus loei Maillieux, 1908a [Ivdelinia (Ivdelinia) loei (Maillieux, 1908a)], RBINS a9574 (lectotype), incomplete and slightly deformed articulated specimen in ventral, dorsal, lateral, posterior, anterior and inclined ventral (arrow: median septum) views, and closeup of ribs and growth lines on the fold near the anterior margin; Couvin 80, Jemelle Formation. Scale bars: $10 \mathrm{~mm}$ (A-C, O-S, T), 5 mm (D-H, I-N, U). 
Pentamerus loei Maillieux, 1908a

(Fig. 7O-U)

1908a Pentamerus Loëi Maillieux: 339-340, figs a-b.

1912 Pentamerus Loëi: Maillieux: 52.

1922a G. [Gypidula] Loei; Maillieux: 15.

1938 Gypidula Loei (Maillieux); Maillieux: 21.

1941b Gypidula loei (Maillieux); Maillieux: 4.

? 1970 Gypidula loeï [sic] Maillieux; Bultynck: 42, 44.

? 1970 Gypidula loei Maillieux; Bultynck: pl. 36.

1971 Pentamerus loëi Maillieux, 1909 [sic]; Godefroid: 47.

1995b [Ivdelinia] loei (Maillieux, 1909) [sic]; Godefroid: 83.

Type material. Among the RBINS collections, only one poorly preserved specimen (RBINS a9574; Fig. 7O-U) identified as such was recovered so far and considered as the type (= lectotype) by Godefroid (1971); Godefroid (1995b) reported that this species is known by a single specimen. The latter is accompanied by several labels bearing Maillieux's handwriting but it is not absolutely certain that this specimen corresponds to that illustrated by Maillieux (1908a, figs a-b). Maillieux's line drawings show a complete but slightly distorted specimen in contrast with the specimen RBINS a9574 that is also distorted, but of which the measurements do not match those indicated by Maillieux (1908a). However, it is not excluded that this author strongly embellished the drawings. This specimen is the only one that can be considered as the model for Maillieux's description. If it would turn out that it is really the only one, it would be considered as the holotype by monotypy. A certainty about this is, however, highly improbable.

Type locality and horizon. Couvin 80, Jemelle Formation (limestone lens) (Eifelian).

Description. See Maillieux (1908a).

Remarks. Maillieux's publication is part of the minutes of the session of the Société belge de Géologie, de Paléontologie et d'Hydrologie that took place on 18 November 1908; they were published in 1908. According to Godefroid (1995b), the type of ornamentation of Pentamerus loei, which consists of wide, medianly grooved costae (Fig. 7U) separated from each other by narrower and subangulose intercostal grooves, is characteristic of the genus Ivdelinia Andronov, 1961. The presence of a ventral median septum (Fig. 7O, T) suggests an assignment to the nominal subgenus Ivdelinia $(I$.$) . The pentamerides from the disused unit$ 'Co2d' (= Hanonet Formation) identified by Godefroid (1971) as Ivdelinia cf. loei (Maillieux) were referred to Gypidula abunda abunda Struve, 1992 by Godefroid (1995b), but those from the 'Co2c' (= Jemelle Formation) need to be re-investigated. Bultynck (1970) cited the species in the Couvin area, notably in its locus typicus (see also Bultynck, 1965), but due to the lack of illustration, it is impossible to confirm that it is really the one erected by Maillieux (1908a).

Current name. Ivdelinia (Ivdelinia) loei (Maillieux, 1908a).

\subsection{Order Rhynchonellida}

Rhynchonella? gosseleti Oehlert, 1893

1893 Rhynchonella? Gosseleti Oehlert: 125-131, text-figs 1-4, pl. 3, figs 5, 6, 7a-d.

Type material, locality and horizon. See Sartenaer \& Plodowski (1975).

Remarks. As rightly exposed by Sartenaer \& Plodowski (1975) in their comprehensive discussion, this species has to be considered as a junior synonym of Araratella moresnetensis (de Koninck, 1887) (see below).

Current name. Araratella moresnetensis (de Koninck, 1887).

Camarotoechia? ingens Maillieux, 1936a

(Fig. 8A-B)

1936a Camarotoechia? ingens Maillieux: 22, 26, 32, 88-89, pl. 1 , fig. 6 .

1940b Camarotoechia ingens Maillieux; Maillieux: 19.

1941b Camarotoechia ingens Maillieux; Maillieux: 8.

1941c Camarotoechia? ingens Maillieux; Maillieux: 3.
1946 Camarotoechia ingens (Maillieux) [sic]; Asselberghs: 150, 329.

Type material. The incomplete and deformed ventral valve RBINS a1068 was selected as the holotype by Maillieux (1936a, pl. 1, fig. 6) and is re-illustrated in Figure 8A-B.

Type locality and horizon. Fauvillers 6, Villé Formation (Siegenian; Pragian).

Description. See Maillieux (1936a).

Remarks. This large species was erected on the basis of a single ventral valve; additional material is required for its revision and to reach a better generic assignment.

Current name. 'Camarotoechia' ingens Maillieux, 1936a.

Terebratula (Atrypa) megistana Le Hon, 1870

(Fig. 8C-G)

1870 Terebratula (Atrypa D’Orb.) megistana Le Hon: 496497, pl. 11, fig. 7, 7 a.

1988 Calvinaria megistana (Le Hon, 1870); Sartenaer: 3446, text-fig. 1, pl. 1, figs 1-3, pl. 2, figs 4-6, pl. 3, figs 7-13, pl. 4, figs 14-21 (see this author for a complete synonymy of this species)

1999 Calvinaria megistana; Godefroid \& Sartenaer in Boulvain et al.: 21-22, figs BIO6-7.

2005a Calvinaria megistana (Le Hon, 1870); Mottequin: 2, 41, 104-105, 329, 376, text-fig. 3.20, pl. 2, figs 11-15.

Type material. A neotype (RBINS a2760) was selected, discussed and illustrated by Sartenaer (1988, pl. 1, fig. 2a-e); it is re-illustrated here (Fig. 8C-G).

Type locality and type horizon. Durbuy 8319, Neuville Formation (late Frasnian).

Description. See Le Hon (1870) and Sartenaer (1988).

Remarks. This species, which ranks among the largest Frasnian rhynchonellides, was assigned to the leiorhynchid genus Calvinaria Stainbrook, 1945 by Stainbrook (1948) and described in detail by Sartenaer (1988).

Current name. Calvinaria megistana (Le Hon, 1870).

\section{Rhynchonella moresnetensis de Koninck, 1887}

1887 Rhynchonella Moresnetensis de Koninck: 58-59, 145, table (unnumbered), pl. 13, figs 17-18.

1975 Araratella moresnetensis (de Koninck, L.-G., 1887); Sartenaer \& Plodowski: 10-27, fig. (unnumbered), pl. 1, figs 1-5, pl. 2, figs $1-4$, pl. 3, figs 1-16 (see these authors for a complete synonymy before 1975).

1983 Araratella moresnetensis; Sartenaer in Robaszynski \& Dupuis: pl. 2, fig. 3

1986 Araratella moresnetensis; Conil et al.: 22-23, table 1, fig. 3 .

1995 Araratella moresnetensis (de Koninck); Legrand-Blain: 79 , table 1.

2003 Araratella moresnetensis; Sartenaer \& Plodowski: 341.

2016 Araratella moresnetensis (de Koninck, 1887); Mottequin \& Brice: 125, fig. 5L-P.

Type material. The distorted articulated specimen (RBINS a1162) illustrated by de Koninck (1887, pl. 13, figs 17-18) was selected as the lectotype by Sartenaer and Plodowski (1975, pl. 1, fig. 4a-e), but has not been traced yet in the RBINS collection.

Type locality and horizon. Astenet, Dolhain Formation (latest Famennian).

Description. See de Koninck (1887) and Sartenaer \& Plodowski (1975).

Remarks. This species is an excellent guide in the field to recognize the uppermost Famennian in southern Belgium (Sartenaer \& Plodowski, 1975; Mottequin \& Brice, 2016). Besides, Sartenaer \& Plodowski (1975) discussed the Famennian species Rhynchonella mourloni Simoens, 1900, which has to be considered as a nomen nudum.

Current name. Araratella moresnetensis (de Koninck, 1887). 

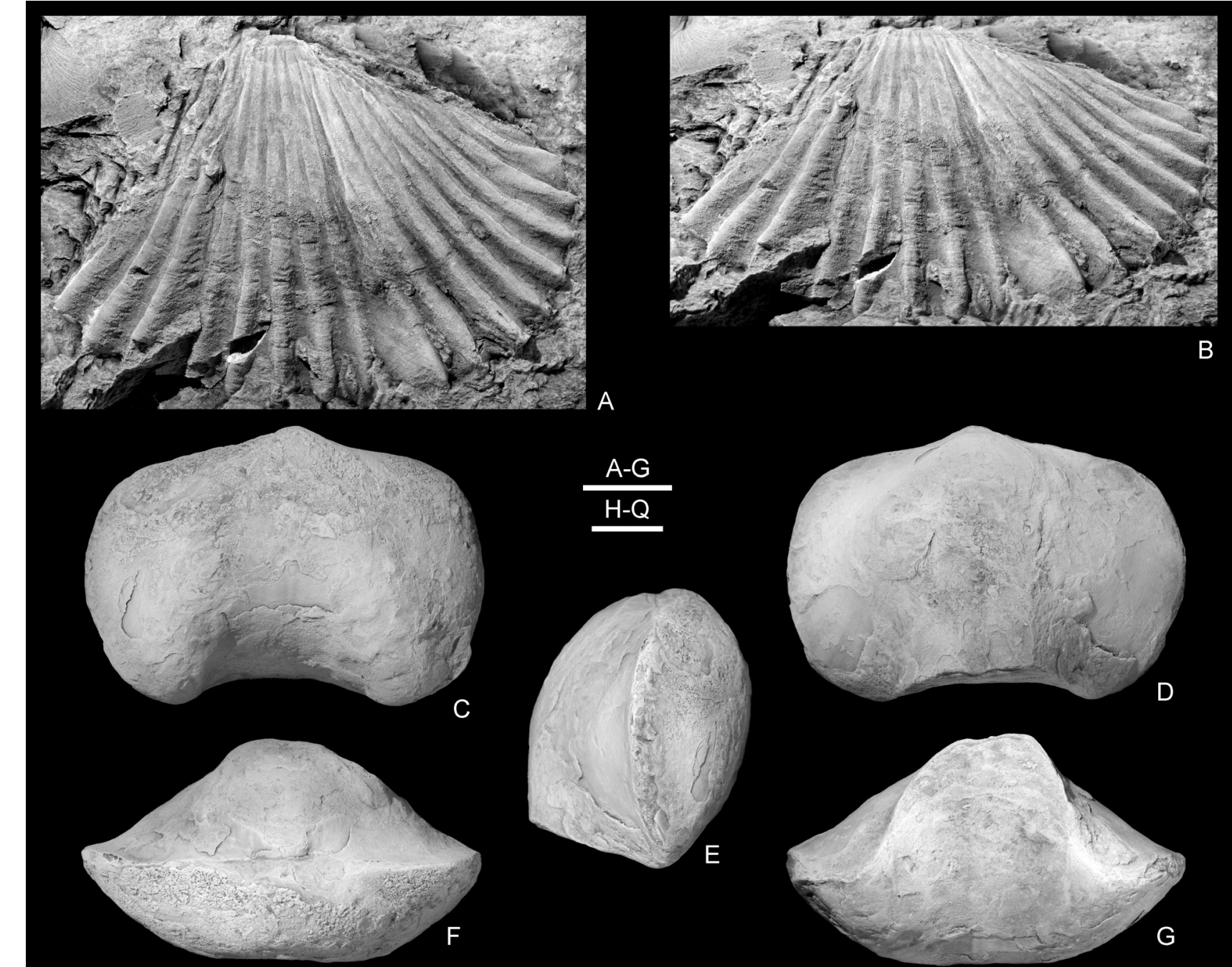

3xing $A$

\section{A}
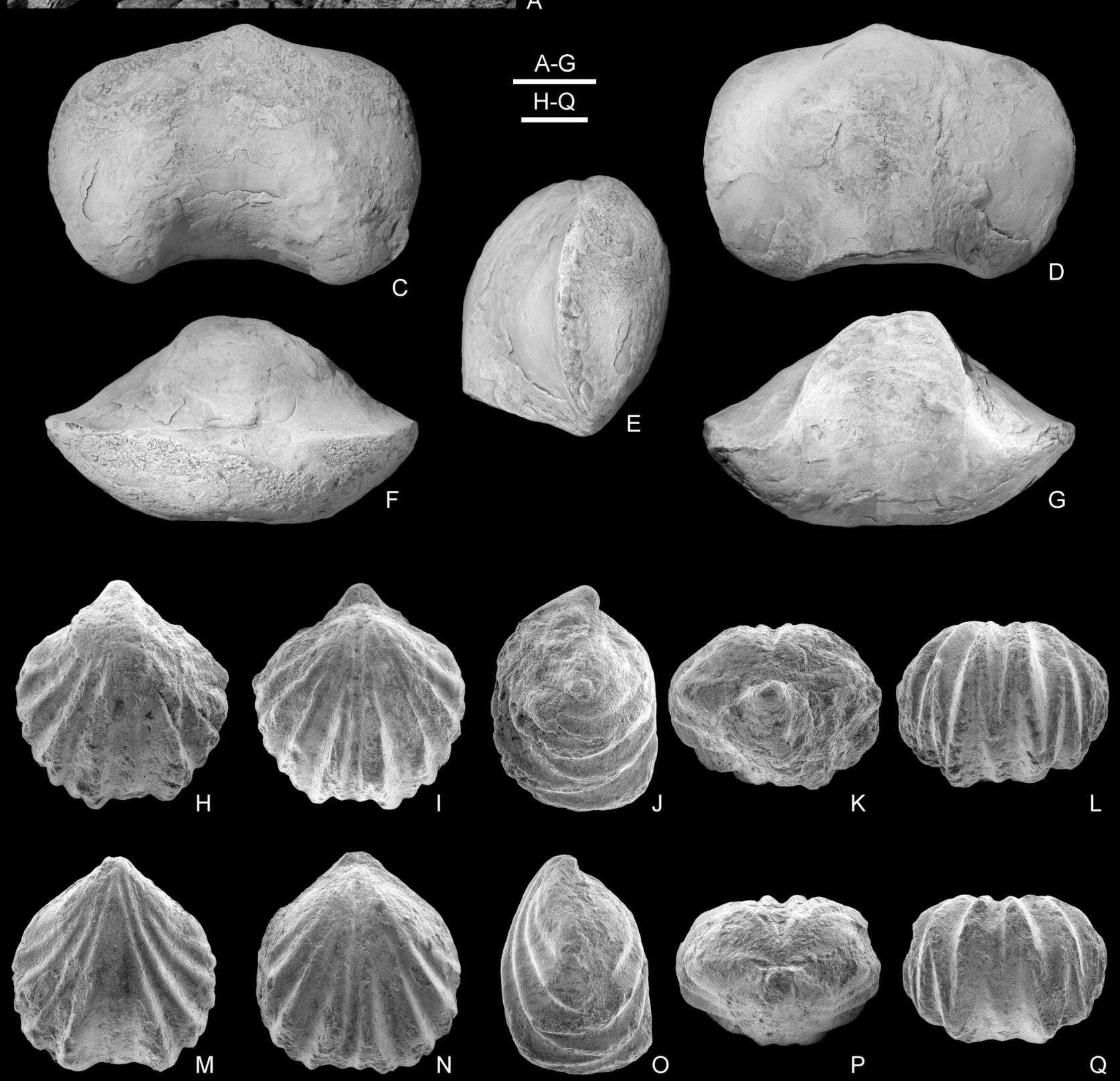

Figure 8. A-B. Camarotoechia? ingens Maillieux, 1936a ['Camarotoechia' ingens Maillieux, 1936a], RBINS a1068 (holotype), crushed incomplete ventral valve in plan and anteroventral views; Fauvillers 6, Villé Formation. C-G. Terebratula (Atrypa) megistana Le Hon, 1870 [Calvinaria megistana (Le Hon, 1870)], RBINS a2760 (neotype), articulated specimen in ventral, dorsal, lateral, posterior and anterior views; Durbuy 8319, Neuville Formation. H-Q. Rhynchonella parvula Béclard, 1891 [Tetratomia? parvula (Béclard, 1891)]; Rochefort 8679 (2), Eau Noire Formation. H-L. RBINS a1689 (lectotype), articulated specimen in ventral, dorsal, lateral, posterior and anterior views. M-Q. RBINS a1690 (paralectotype), articulated specimen in ventral, dorsal, lateral, posterior and anterior views. Scale bars: $10 \mathrm{~mm}(\mathrm{~A}-\mathrm{G}), 1 \mathrm{~mm}(\mathrm{H}-\mathrm{Q})$. 
Rhynchonella parvula Béclard, 1891

(Fig. 8H-Q)

1891 Rhynchonella parvula Béclard: 97-98, 99, 100, pl. 3, figs 1-2.

1913 Retzia? parvula; Maillieux: 10, 14.

1922a Retzia parvula; Maillieux: 14.

1933 Ptychospira parvula (Béclard); Maillieux: 66.

1941b Ptychospira parvula (Béclard); Maillieux: 12.

1965 'Rhynchonella' parvula Béclard 1891; Godefroid: B88, pl. (unnumbered), figs $4,5 \mathrm{a}-\mathrm{c}$.

1967 Tetratomia parvula; Lecompte: 30, 43, pls 6, 16.

1968 Tetratomia? parvula (Béclard, 1891); Godefroid: cited many times, pls 4-5, 8-9.

1970 Tetratomia? parvula; Bultynck: cited many times, pls $36,37$.

1970 Tetratomia parvula; Lecompte: 62, table 2.

1971 Tetratomia? parvula; Tsien: 123.

1982 Tetratomia parvula; Bultynck et al.: 32-33, text-fig. 1.

1983 Tetratomia parvula; Rzhonsnitskaya: 7, 9, table 1.

1983 Tetratomia parvula; Sartenaer in Robaszynski \& Dupuis: 193, pl. 2, fig. 20.

1983 Tetratomia parvula; Vandenven \& Godefroid in Robaszynski \& Dupuis: 126.

1994 Tetratomia parvula (Béclard, 1891); Godefroid in Godefroid et al.: 17, fig. 11.

Type material. The articulated specimen RBINS a1689 (Béclard, 1891, pl. 3, fig. 1; Godefroid, 1965, fig. 5a-c; Sartenaer in Robaszynski \& Dupuis, 1983, pl. 2, fig. 20) is hereby designated as the lectotype and figured in Figure 8H-L. The articulated specimen RBINS a1690 (Béclard, 1891, pl. 3, fig. 2) is a paralectotype (Fig. 8M-Q). Béclard's (1891) drawings are clearly embellished.

Type locality and horizon. Rochefort 8679 (2), Eau Noire Formation (late Emsian).

Description. See Béclard (1891) and Godefroid (1965).

Remarks. The Jurassic species Rhynchonella parvula EudesDeslongchamps, 1862 (the type species of Parvirhynchia Buckman, 1918; see also Alméras \& Lathuilière, 1984) and Rhynchonella parvula Béclard, 1891 from the Devonian of southern Belgium are primary homonyms (Articles 53.3, 57.2 of the Code). According to the Article 23.9.5 of the Code and the current survey of the literature, it appears that the Devonian species was not considered as belonging to the same genus after 1899 , thus in order to preserve the nomenclature stability, Béclard's specific name is not replaced. From Lecompte (1967), Béclard's species has been transferred (doubtfully or otherwise) to Tetratomia Schmidt, 1946 by subsequent workers. Godefroid (1965) and García-Alcalde in Arbizu et al. (1979) considered the German species Rhynchonella amanshauseri Dahmer, 1923 as a synonym of Béclard's species, but this opinion was not accepted by Brice (1981), who was not convinced that the latter belongs to Tetratomia. The species parvula was listed on many occasions in the Emsian of the Cantabrian Mountains (Spain), notably by García-Alcalde (2015). However, Tetratomia? parvula urgently needs to be revised (internal features unknown, except the presence of a long dorsal septum illustrated by Godefroid (1965, fig. 4)) and its conspecificity with the Spanish form has to be confirmed (or otherwise) (J.L. García-Alcalde, pers. com., November 2018). That is why the Spanish records are not included in the synonymy list.

Current name. Tetratomia? parvula (Béclard, 1891).

Plethorhyncha? percostata Fuchs, var. gdoumontensis Asselberghs, 1930

(Fig. 9A-T)

1929 Plethoryncha? [sic] percostata Fuchs var. gdoumontensis Asselberghs [nomen nudum]: 758.

1930 Plethoryncha? [sic] percostata Fuchs, var. gdoumontensis Asselberghs: 33-34, 62.

1930 Plethorhyncha? percostata Fuchs, var. gdoumontensis Asselberghs: pl. 3, figs 20-24. 1941a Camarotoechia percostata gdoumontensis (Asselberghs); Maillieux: 8.

1942 Camarotoechia sinuosa (A. Fuchs 1923); Dahmer: 119, 129-132.

1943a Plethorhyncha? percostata var. gdoumontensis; Asselberghs: 7, 9.

1946 Camarotoechia sinuosa Fuchs; Asselberghs: 328.

1960 'Camarotoechia' sinuosa (Fuchs, 1923); Boucot: 309310 , tables 2, 3, pl. 15, figs 5-15, pl. 16, figs 1-2.

1973 Bathyrhyncha sinuosa gdoumontensis (Asselberghs 1930); Struve: 352, 357, fig. 17a-b.

1994 Bathyrhyncha sinuosa Fuchs, 1923; Godefroid in Godefroid et al.: 17, fig. 13.

Type material. The internal mould of a dorsal valve (RBINS a3226; Fig. 9A-D) figured by Asselberghs (1930, pl. 3, fig. 24) is hereby designated as the lectotype. The paralectotypes includes the external moulds of ventral and dorsal valves (RBINS a544 (also illustrated by Boucot, 1960, pl. 15, fig. 9); Fig. 9E-H), the internal and external moulds of a ventral valve (RBINS a3223; Fig. 9I-K), and the ventral internal moulds (RBINS a3224-3225; Fig. 9L-O, P-T) that were illustrated by Asselberghs (1930, pl. 3, figs 20-23).

Type locality and horizon. Malmedy 12 (Gdoumont), Marteau Formation, Waimes Member (earliest Gedinnian; Pridoli).

Description. See Asselberghs (1930), Dahmer (1942), and Boucot (1960).

Remarks. Asselberghs (1930) erected a new variety for 'Rhynchonella' percostata Fuchs, 1919, a species which was assigned by Brice (1986) to her new genus Pachanchorhynchia. According to Dahmer (1942, 1951), Asselberghs' (1930) variety is identical with Bathyrhyncha sinuosa Fuchs, 1923 (see Table 1), an opinion followed by Asselberghs (1943a) and Boucot (1960).

Current name. Bathyrhyncha sinuosa Fuchs, 1923.

Leiorhynchus tumidus var. quadricostata Maillieux, 1930 (Fig. 9U-DD)

1930 Leiorhynchus tumidus (Kayser) var. quadricostata Maillieux: 108-109, pl. 3, fig. 4a-b.

1936b Leiorhynchus tumidus (Kayser) var. quadricostata Maillieux; Maillieux: 24.

1941b Leiorhynchus tumidus quadricostatus Maillieux; Maillieux: 9.

1968 Leiorhynchus tumidus (Kayser) var. quadricostata Maillieux; Sartenaer: 8.

Type material. The specimen RBINS a10301A (Maillieux, 1930, pl. 3, fig. 4a; Sartenaer, 1968, pl. 1, fig. 4a-e) was selected as the lectotype (Fig. 9U-Y) of Maillieux's variety by Sartenaer (1968) (see remarks below). According to the Article 74.1.3 of the Code, the specimens RBINS a10301C (Sartenaer, 1968, pl. 1, fig. 3a-e; Fig. 9Z-DD) and RBINS a10301B (lost!) (Maillieux, 1930, pl. 3, fig. 4b) are paralectotypes of this variety.

Type locality and horizon. Sautour 7605, Matagne Formation (late Frasnian).

Description. See Maillieux (1930, 1936b).

Remarks. Conformably to the Article 45.6.4 of the Code, Sartenaer (1968) pointed out that both varieties (Leiorhynchus tumidus var. quadricostata and L. tumidus var. tricostata) erected by Maillieux (1930) have a subspecific rank. Sartenaer (1968) considered them as synonyms of Camarophoria tumida Kayser, 1872, which is the type species of the genus Ryocarhynchus Sartenaer, 1984 and particularly abundant at the end of the Frasnian in southern Belgium, northern France and western Germany (Sartenaer, 1968, 1974b; Mottequin \& Poty, 2016) but also in the upper Frasnian of southern Poland (Baliński 1979, 2002).

Current name. Ryocarhynchus tumidus (Kayser, 1872).

\section{Leiorhynchus tumidus var. tricostata Maillieux, 1930}

1930 Leiorhynchus tumidus (Kayser) var. tricostata Maillieux: 108, pl. 3, fig. 3a-b. 

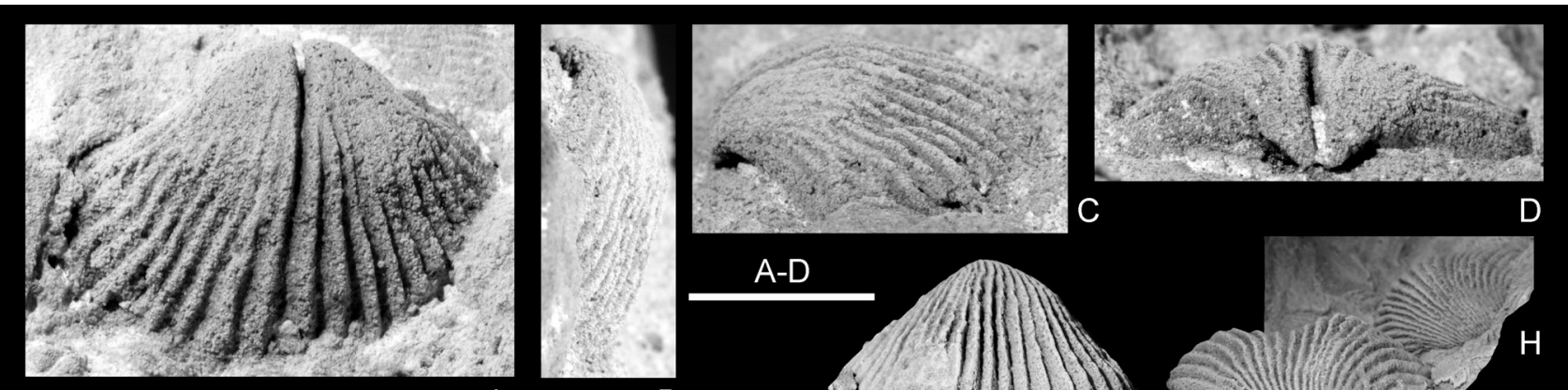

B
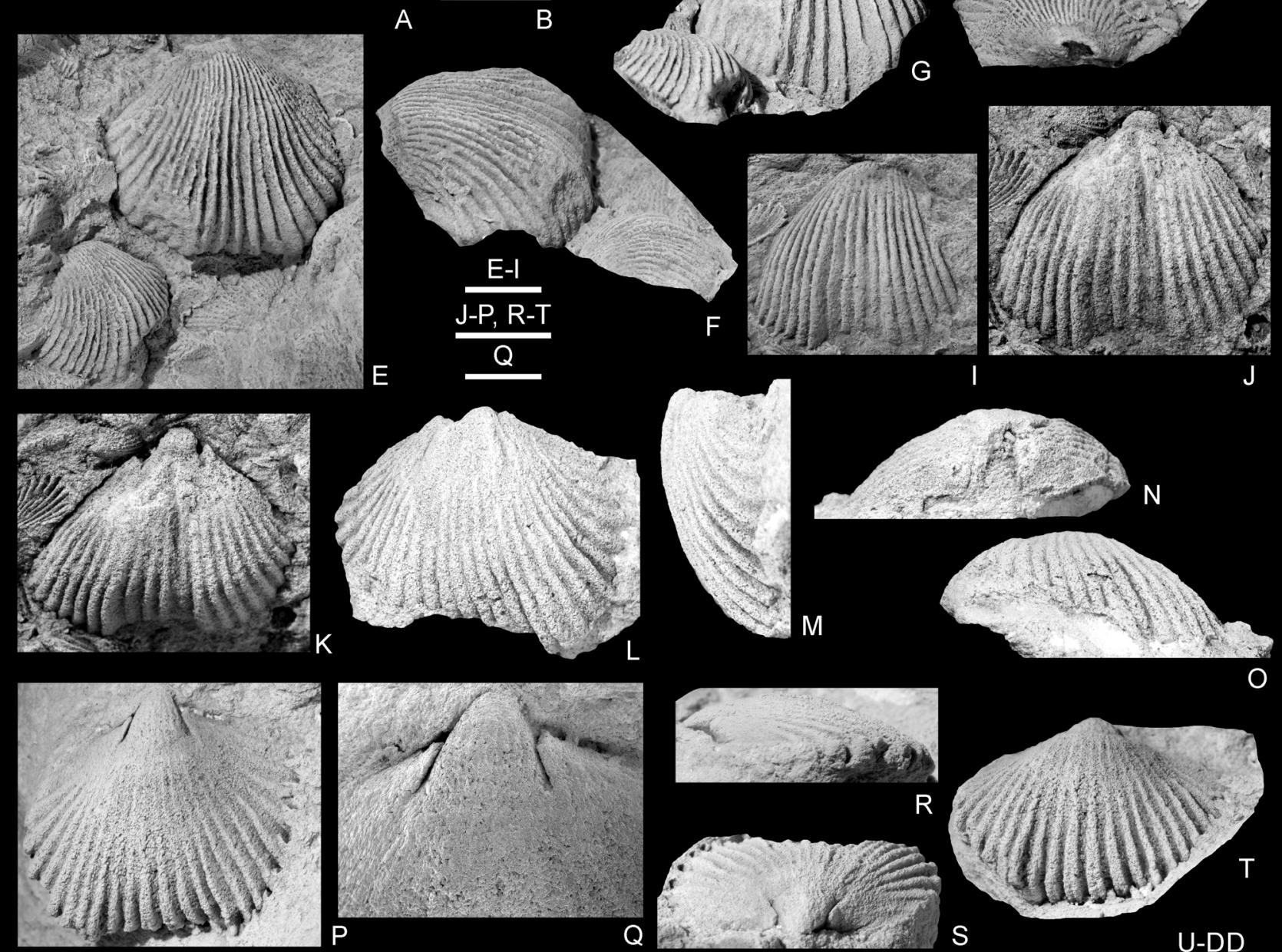

O

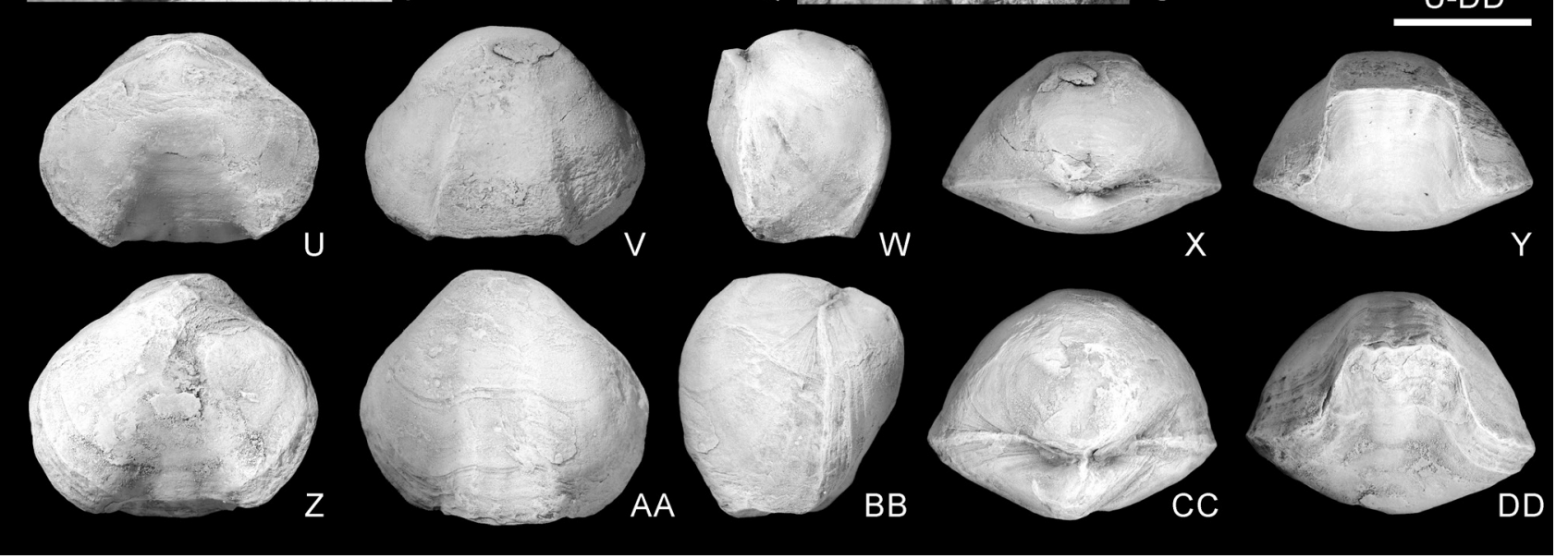

Figure 9. A-T. Plethorhyncha? percostata Fuchs, var. gdoumontensis Asselberghs, 1930 [Bathyrhyncha sinuosa Fuchs, 1923]; Malmedy 12 (Gdoumont), Marteau Formation (Waimes Member). A-D. RBINS a3226 (lectotype), internal mould of a dorsal valve in plan, lateral, oblique lateral and posterior views. E-H. RBINS a544, putty cast of the external moulds of ventral and dorsal valves in different views. I-K. RBINS a3223, putty cast of a ventral valve in plan view, and internal mould of a ventral valve in in plan and inclined plan views. L-O. RBINS a3224, internal mould of a ventral valve in plan, lateral, posterior and anterior views. P-T. RBINS a3225, internal mould of a ventral valve in plan, lateral, posterior and anteroventral views and close-up of the umbonal region (Q, SEM). U-DD. Leiorhynchus tumidus var. quadricostata Maillieux, 1930 [Ryocarhynchus tumidus (Kayser, 1872)]; Sautour 7605, Matagne Formation. U-Y. RBINS a10301A (lectotype), articulated specimen in ventral, dorsal, lateral, posterior and anterior views. Z-DD. RBINS a10301C, articulated specimen in ventral, dorsal, lateral, posterior and anterior views. Scale bars: $5 \mathrm{~mm}$ (A-D, E-I, J-P, R-T), $2 \mathrm{~mm}(\mathrm{Q}), 10 \mathrm{~mm}(\mathrm{U}-\mathrm{DD})$. 
1936b Leiorhynchus tumidus (Kayser) var. tricostata Maillieux; Maillieux: 23.

1941b Leiorhynchus tumidus tricostatus Maillieux; Maillieux: 9.

1968 Leiorhynchus tumidus var. tricostata Maillieux; Sartenaer: 8.

Type material. Sartenaer (1968) selected the specimen RBINS a10300 (Maillieux, 1930, pl. 3, fig. 3a-b) as the lectotype of Maillieux's variety (see remarks above related to Leiorhynchus tumidus var. quadricostata), but it has not been traced in the RBINS collections.

Type locality and horizon. Sautour 7605, Matagne Formation (late Frasnian).

Description. See Maillieux (1930, 1936b).

Remarks. See Leiorhynchus tumidus var. quadricostata.

Current name. Ryocarhynchus tumidus (Kayser, 1872).

\subsection{Order Athyridida}

Retzia crassicosta Maillieux, 1932

(Fig. 10A-C)

1932 Retzia crassicosta Maillieux: 59, pl. 2, fig. 6.

1933 Retzia crassicosta Maillieux; Maillieux: 59.

1941a Retzia crassicosta Maillieux; Maillieux: 12, 59.

1941b Retzia crassicosta Maillieux; Maillieux: 12.

1946 Retzia crassicosta Maillieux; Asselberghs: 247, 330.

1989 Retzia crassicosta Mailieux [sic], 1932; Grunt: 90.

Type material. Maillieux (1932, pl. 2, fig. 6) illustrated an internal mould of a dorsal valve (RBINS a973; Fig. 10A-C), but failed to designate a holotype. As he clearly stated that this specimen is the single one available, it has thus to be considered as the holotype by monotypy.

Type locality and horizon. Vireux-Molhain 2 (France), base of the Hierges Formation according to Godefroid \& Stainier (1988) (late Emsian).

Description. See Maillieux (1932).

Remarks. This poorly known species, which differs from Retzia adrieni (de Verneuil \& d'Archiac, 1845) in the number of costae and the subtriangular outline of the dorsal valve according to Maillieux (1932), needs to be revised on the basis of further material.

Current name. Retzia crassicosta Maillieux, 1932.

Athyris dorlodoti Asselberghs, 1923

(Fig. 10D-V)

p 1895 Athyris concentrica, v. Buch; Kayser: 207, pl. 3, figs 8-9.

1922 Athyris Dorlodoti Asselberghs [nomen nudum]: B132, B134.

1923 Athyris Dorlodoti Asselberghs: 11, 34-35, 58, 59, tables 1-2, pl. 2, figs 6-8.

1933 Athyris Dorlodoti; Maillieux: 67.

1938 Athyris Dorlodoti Asselberghs; Maillieux: 12.

1941b Athyris dorlodoti Asselberghs; Maillieux: 12.

1955 Athyris dorlodoti Asselberghs; Asselberghs: 209.

1977 Athyris dorlodoti (E. Asselberghs, 1923); Bultynck \& Boonen: 492.

1989 Athyris dorlodoti Asselberghs, 1929 [sic]; Grunt: 83.

Type material. Asselberghs (1923, legend of pl. 2, figs 6-8) considered the illustrated specimens as the types but he did not select a holotype. The internal mould of a ventral valve (with external mould) (RBINS a3167; Fig. 10H-L) figured by Asselberghs (1923, pl. 2, fig. 7a-b), which seems to have been deformed by fish bites, is hereby selected as the lectotype. The internal mould of a ventral valve (ULg.PA.2018.12.23/1; Fig. 10D-G) figured by Kayser (1895, pl. 3, fig. 8) and Asselberghs (1923, pl. 2, fig. 6), and that of an incomplete dorsal valve with external mould (RBINS a3168; Fig. 10L-V) illustrated by Asselberghs (1923, pl. 2, fig. 8a-c) are paralectotypes.

Type locality and horizon. Chênée 5381 (Tilff), Pépinster Formation (Eifelian-Givetian).
Description. See Asselberghs (1923).

Remarks. This species with a long dorsal myophragm is abundant within the Pépinster and Rivière formations according to Asselberghs (1923), but needs to be revised in order to be compared validly with the numerous athyridid species recognized in the Eifelian of western Germany (Struve, 1992; Alvarez et al., 1996; Grunt \& Weyer, 2016).

Current name. Athyris dorlodoti Asselberghs, 1923.

Retzia gdoumontensis Asselberghs, 1930

(Fig. 11A-D)

1929 Retzia gdoumontensis Asselberghs [nomen nudum]: 758 .

1930 Retzia gdoumontensis Asselberghs: 41, 63, pl. 5, figs 5-6.

1933 Retzia gdoumontensis Asselberghs; Maillieux: 43.

1941b Retzia gdoumontensis Asselberghs; Maillieux: 12.

1942 Retzia gdoumontensis Asselberghs; Dahmer: 120.

1943a Retzia gdoumontensis Asselberghs; Asselberghs: 10.

1943b Retzia gdoumontensis Asselberghs; Asselberghs: 7, 10, 12.

1946 Retzia gdoumontensis Asselberghs; Asselberghs: 328.

1960 Homeospira gdoumontensis (Asselberghs, 1930);

Boucot: 317-318, tables 2, 3, pl. 17, figs 10-15.

1967 Homeospira gdoumontensis; Lecompte: 29.

1982 Homeospira gdoumontensis (Asselberghs, E., 1930); Godefroid: 126, table 3.

1989 Homeospira gdoumontensis Asselberghs, 1903 [sic]; Grunt: 91.

1994 Homeospira gdoumontensis (Asselberghs, 1930); Godefroid in Godefroid et al.: 19, fig. 13.

1999 Homeospira gdoumontensis; Godefroid \& Cravatte: 12 13 , table 1.

Type material. The external mould of a dorsal valve (RBINS a3245; Fig. 11A-B) figured by Asselberghs (1930, pl. 5, fig. 5) is hereby designated as the lectotype whereas the external mould of a ventral valve (RBINS a3246; Fig. 11C-D) illustrated in Asselberghs (1930, pl. 5, fig. 6) is a paralectotype.

Type locality and horizon. Malmedy 9 (Ovifat), Marteau Formation, Waimes Member (earliest Gedinnian; Pridoli).

Description. See Asselberghs (1930) and Boucot (1960).

Remarks. Markedly better preserved material was figured by Boucot (1960), who assigned Asselberghs' (1930) species to Homeospira Hall \& Clarke, 1893.

Current name. Homeospira gdoumontensis (Asselberghs, 1930).

Meristella straeleni Asselberghs, 1930

(Fig. 11H-J)

1929 Meristella Straeleni Asselberghs [nomen nudum]: 758. p 1930 Meristella Straeleni Asselberghs: 42, 63, pl. 5, figs 7-8 (see remarks below).

1933 Meristella Staeleni [sic] [corrected in the erratum]; Maillieux: 43.

1941b Meristella straeleni Asselberghs; Maillieux: 11.

1942 Meristella straeleni Asselberghs; Dahmer: 120.

1943a Meristella straeleni Asselberghs; Asselberghs: 10.

1943b Meristella straeleni Asselberghs; Asselberghs: 4, 7,

$10,12$.

1946 Meristella straeleni Asselberghs; Asselberghs: 328.

1960 Protathyris? straeleni (Asselberghs, 1930); Boucot: 312-313, tables 2, 3, pl. 18, figs 15-16.

1982 Protathyris? Straeleni (Asselberghs, E., 1930); Godefroid: 126, table 3.

1989 Meristella straeleni Asselberghs, 1930; Grunt: 81.

1994 Protathyris? straeleni (Asselberghs, 1930); Godefroid in Godefroid et al.: 19, fig. 13.

1999 ? Protathyris straeleni (Asselberghs, 1930); Godefroid \& Cravatte: 9, table 1, figs 3-4.

Type material. The illustrated syntypes include the dorsal internal mould (RBINS a583; Fig. 11H-J) illustrated by Asselberghs (1930, pl. 5, fig. 8) and Boucot (1960, pl. 18, fig. 16) and a poorly preserved internal mould of a juvenile ventral valve 


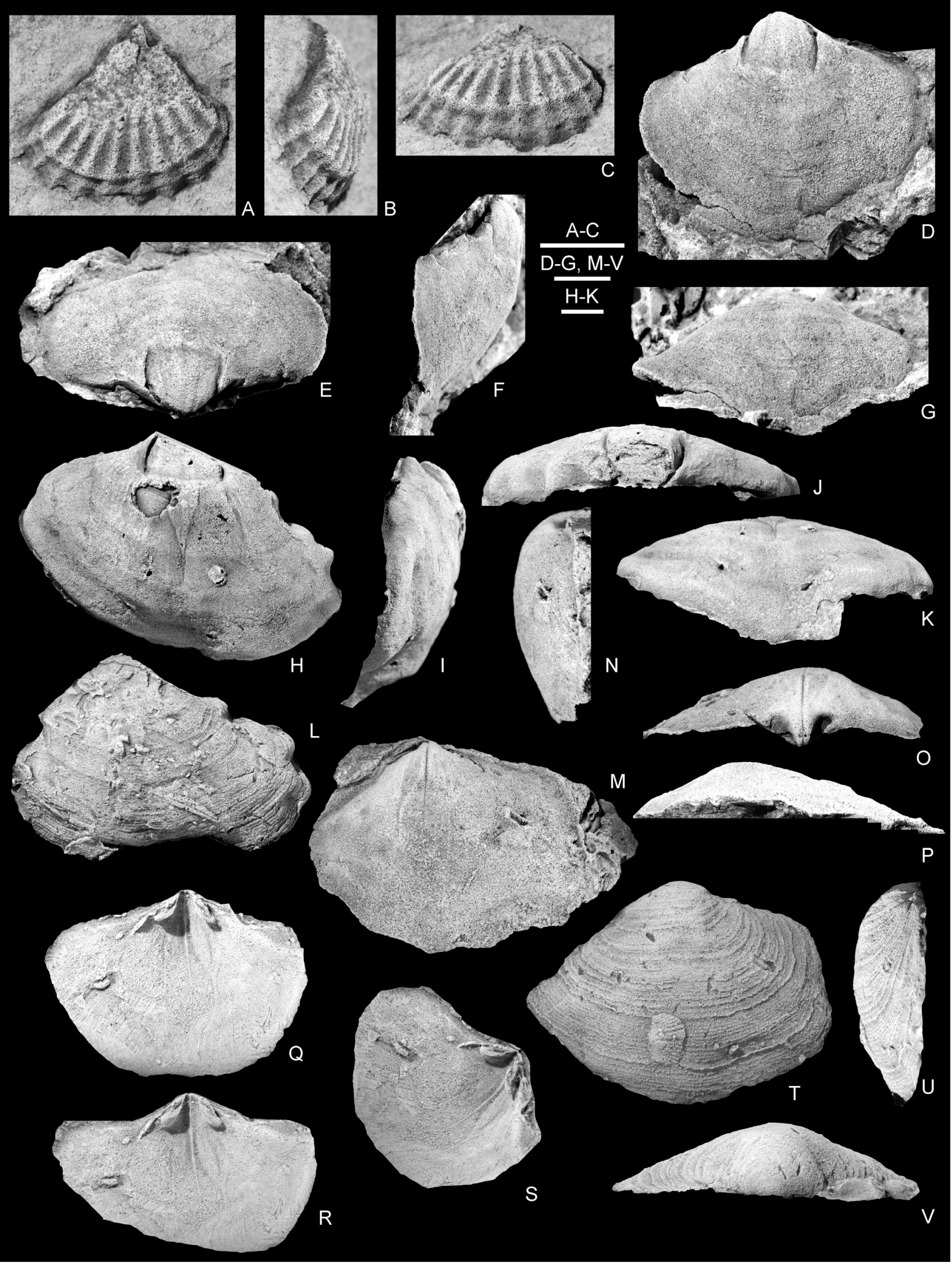

Figure 10. A-C. Retzia crassicosta Maillieux, 1932, RBINS a973 (holotype), internal mould of a dorsal valve in plan, lateral and anterodorsal views; Vireux-Molhain 2, Hierges Formation. D-V. Athyris dorlodoti Asselberghs, 1923; Chênée 5381 (Tilff), Pépinster Formation. D-G. ULg.PA.2018.12.23/1 (paralectotype), internal mould of a ventral valve in plan, posteroventral, slightly inclined lateral and anterior views. H-L. RBINS a3167 (lectotype), internal mould of a ventral valve in ventral, lateral, posterior and anterior views, and putty cast of exterior. M-V. RBINS a3168 (paralectotype), internal mould of a dorsal exterior in plan, lateral, posterior and anterior views (M-P), putty cast of interior in plan, anterodorsal, and oblique lateral views (Q-S), putty cast of exterior in plan, lateral and posterior views. Scale bars are $5 \mathrm{~mm}$. 


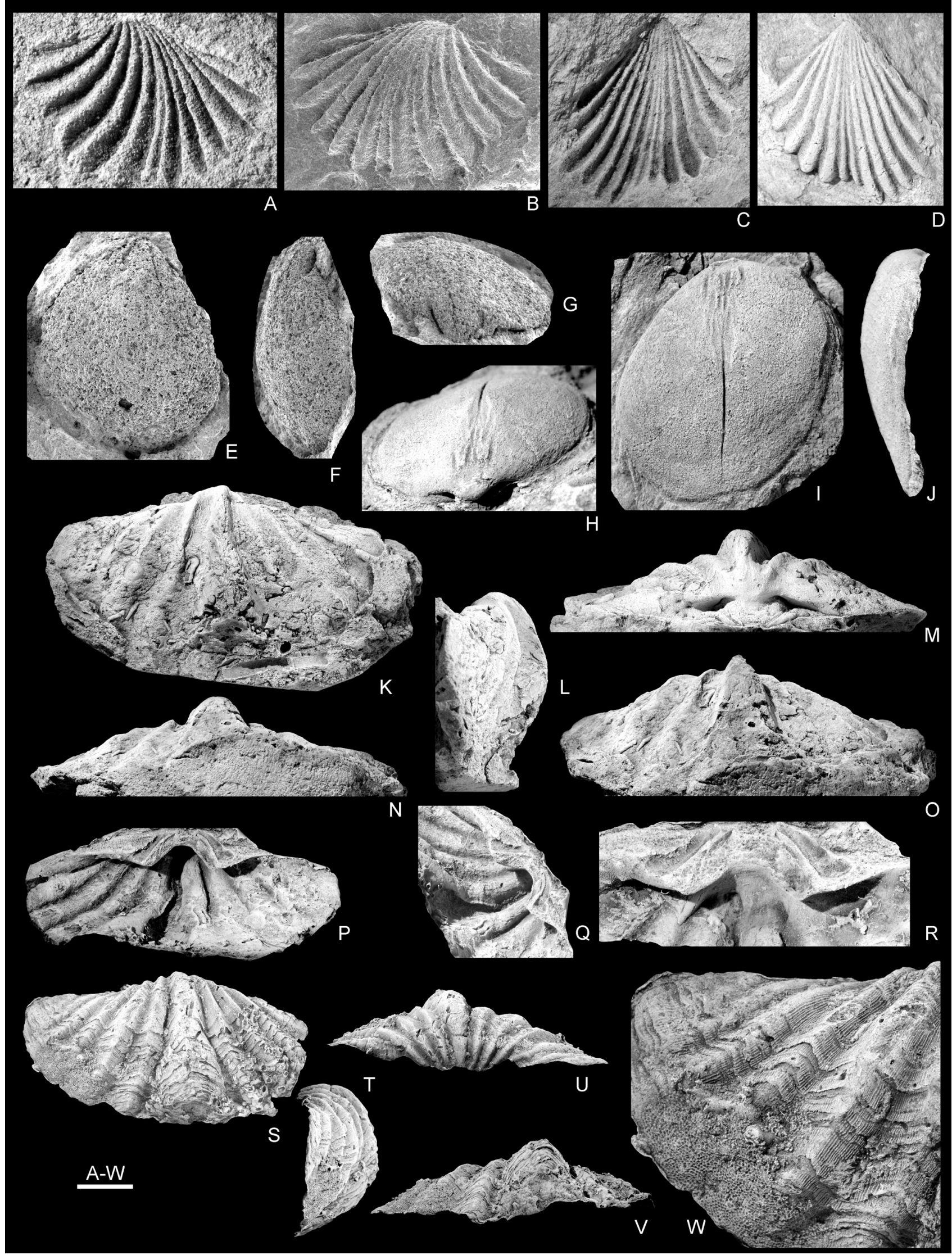

Figure 11. A-D. Retzia gdoumontensis Asselberghs, 1930 [Homeospira gdoumontensis (Asselberghs, 1930)]; Malmedy 9 (Ovifat), Marteau Formation (Waimes Member). A-B. RBINS a3245, dorsal external mould and putty cast (B; SEM). C-D. RBINS a3246, ventral external mould and putty cast. E-J. Meristella straeleni Asselberghs, 1930 [Protathyris? straeleni (Asselberghs, 1930)], syntypes illustrated by Asselberghs (1930); Marteau Formation (Waimes Member). E-G. RBINS a3247, juvenile ventral valve in ventral, oblique lateral and posteroventral views (SEM) (this specimen was rejected from the species by Boucot (1960)); Malmedy 12 (Gdoumont). H-J. Meristella straeleni Asselberghs, 1930, RBINS a583, dorsal valve in posterodorsal, dorsal and lateral views; Malmedy 9 (Ovifat). K-W. Spirifer beaujeani Béclard, 1887 [Filispirifer? beaujeani (Béclard, 1887)], RBINS a1254 (lectotype), internal mould of a dorsal valve in plan, lateral, posterior, anterior, and anterodorsal views (K-O), latex cast of dorsal internal mould in plan and oblique lateral views, detail of the cardinalia (P-R), latex cast of dorsal external mould (with bryozoans and tabulates) in plan, lateral, posterior and anterior views (S-V), and close-up of the left dorsal flank showing the microornament and the bryozoans (W); Saint-Hubert 3 (23), Villé Formation. Scale bar: $2.5 \mathrm{~mm}$ (A-B), $4 \mathrm{~mm}$ (C-D, H-J, W), $2 \mathrm{~mm}(\mathrm{E}-\mathrm{G}), 5 \mathrm{~mm}(\mathrm{R}), 10 \mathrm{~mm}(\mathrm{~K}-\mathrm{Q}, \mathrm{S}-\mathrm{V})$. 
(RBINS a3247; Fig. 11E-G) figured by Asselberghs (1930, pl. 5, fig. 7). The latter was rejected from the species straeleni by Boucot (1960, see his synonymy list), but not discussed. No lectotype is selected at this stage (see the discussion of the species pruvosti in paragraph 4.11).

Type locality and horizon. Malmedy 9 (Ovifat), Marteau Formation, Waimes Member (earliest Gedinnian; Pridoli).

Description. See Asselberghs (1930) and Boucot (1960).

Remarks. This species was doubtfully referred to Protathyris Kozłowski, 1929 by Boucot (1960), who pointed out the absence of ventral valve in the available material. He assigned the dorsal internal mould RBINS a582 (Asselberghs, 1930, pl. 4, fig. 3; Boucot, 1960, pl. 18, fig. 15; Fig. 19L-Q), which was part of the type material of Dielasma pruvosti Asselberghs, 1930, to $P$ ? straeleni (see a more detailed discussion in paragraph 4.11 concerning the species pruvosti).

Current name. Protathyris? straeleni (Asselberghs, 1930).

\subsection{Order Atrypida}

Atrypa gedinniana Fuchs, 1934

(Fig. 12A-G)

1876 Atrypa reticularis Linn.; de Koninck: 44

1929 Atrypa lorana Fuchs; Asselberghs: 758.

1930 Atrypa lorana Fuchs; Asselberghs: 35-36, 63, pl. 4, figs 4-6.

1934 Atrypa gedinniana Fuchs: 402, 404

p 1941b Atrypa lorana Fuchs; Maillieux: 11 (only those from the 'Gedinnian').

1942 Atrypa gedinniana A. Fuchs, 1934; Dahmer: 142, figs 18-19.

1943a Atrypa gedinniana A. Fuchs; Asselberghs: 7-8, 10.

1943b Atrypa gedinniana; Asselberghs: 7, 8, 10, 12.
1946 Atrypa gedinniana Fuchs; Asselberghs: 328.

1951 Atrypa gedinniana Fuchs 1934; Dahmer: 114, pl. 2, fig. 24a-c.

1960 Atrypa gedinniana Fuchs, 1934; Boucot: 310-311, pl. 16, figs 3-6, tables 2-3. able 3 .

982 Atrypa gedinniana Fuchs, A., 1934; Godefroid: 126

1985 Atrypa (? Atrypa) gedinniana Fuchs 1934; Copper \& Rachebœuf: 66, 74, text-fig. 5, pl. 5, figs 1-13.

1994 Atrypa (? Atrypa) gedinniana (Fuchs, 1934) [sic]; Godefroid in Godefroid et al.: 17, fig. 11.

1999 Atrypa (? Atrypa) gedinniana (Fuchs, 1934) [sic]; Godefroid \& Cravatte: 8, 9, 10, 11, 12, 13, table 1, figs 3, 4.

Type material. The ventral external and internal moulds (RBINS a3231; Fig. 12A-C) illustrated by Asselberghs (1930, pl. 4, fig. 5a-b) was selected by Dahmer (1942) as the lectotype and re-illustrated by Copper \& Rachebœuf (1985, pl. 5, figs 1-3). The specimens RBINS a3230 (Asselberghs, 1930, pl. 4, fig. 4a-b; Copper \& Rachebœuf, 1985, pl. 5, figs 6, 8-9; Fig. 12E-G) and a3232 (Asselberghs, 1930, pl. 4, fig. 6; Copper \& Rachebœuf, 1985, pl. 5, figs 4-5; Fig. 12D) are paralectotypes.

Type locality and horizon. Malmedy 9 (Ovifat), Marteau Formation, Waimes Member (earliest Gedinnian; Pridoli).

Description. See Asselberghs (1930), Fuchs (1934), Dahmer (1942), Boucot (1960), and Copper \& Rachebœuf (1985).

Remarks. This species is one of the rare representatives of the Order Atrypida within the Pridolian-Emsian siliciclastic succession of southern Belgium (Godefroid in Godefroid et al., 1994). The specimens from the upper Emsian of the Armorican Massif (France) doubtfully assigned to Fuchs' species by Copper (1981) were subsequently considered as a new species (Atrypa (A.) lezaisensis) by Copper \& Rachebœuf (1985).

Current name. Atrypa (Atrypa?) gedinniana Fuchs, 1934.

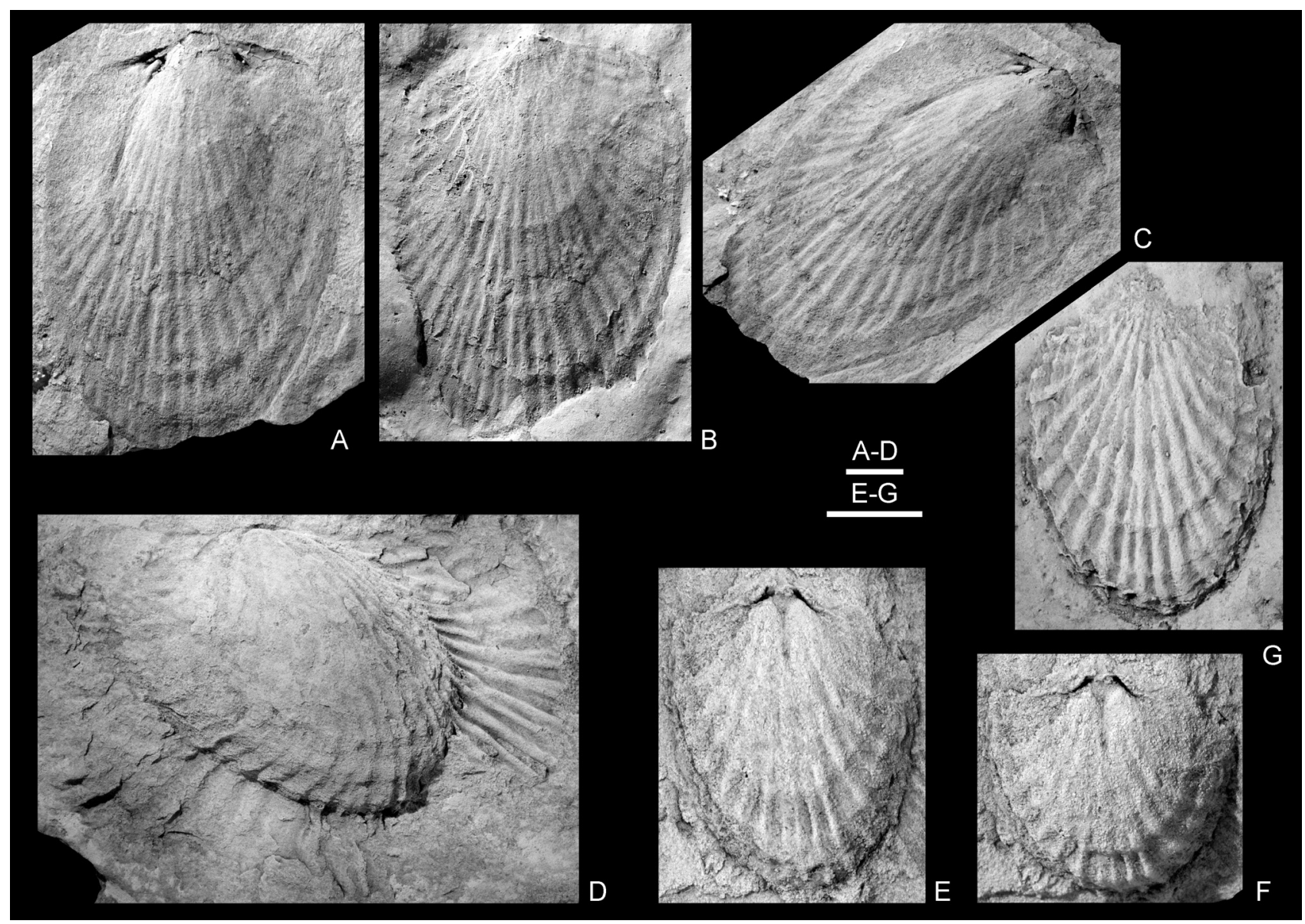

Figure 12. Atrypa gedinniana Fuchs, 1934 [Atrypa (Atrypa?) gedinniana Fuchs, 1934], Malmedy 9 (Ovifat), Marteau Formation (Waimes Member). A-C. RBINS a3231 (lectotype), ventral interior in plan view, ventral exterior (putty cast) in plan view, and ventral interior in oblique lateral view. D. RBINS a3232, dorsal interior in plan view (skirt partly preserved). E-G. RBINS a3230, dorsal interior of a juvenile specimen in plan and oblique posterior views, and ventral exterior (putty cast) in plan view. Scale bars: $5 \mathrm{~mm}$ 


\subsection{Order Spiriferida}

Spirifer beaujeani Béclard, 1887

(Figs $11 \mathrm{~K}-\mathrm{W}, 13 \mathrm{~A}-\mathrm{F}$ )

1887 Spirifer Beaujeani Béclard: 64, 73, pl. 3, figs 1-3. 1896a Spirifer Beaujeani F. Béclard, 1887; Béclard: 141, 146, pl. 11, fig. 3, 3a (= copy of Béclard, 1887, pl. 3, figs 1-2).

1896b Spirifer Beaujeani F. Béclard, 1887; Béclard: 265.

p 1910b Spirifer primaevus Stein.; Maillieux: 194.

p 1910c Spirifer primaevus Steininger; Maillieux: 345-348, $372,376$.

1963 Acrospirifer beaujeani (F. Béclard, 1887);

Vandercammen: 6-12, 149, 152, text-figs 1-3, pl. 1, figs 1-12.

1967 Acrospirifer beaujani [sic]; Lecompte: 42, pl. 15.

1970 Acrospirifer beaujeani (Béclard, F., 1887);

Vandercammen \& Vandercammen-Goffinet: 6, 73.

1982 Acrospirifer beaujani [sic]; Godefroid \& Stainier: 156157 , table $2 \mathrm{a}-\mathrm{b}$.

1989 A. [Acrospirifer] beaujani [sic] (Béclard, 1887); Gourvennec: 66-67.

1994 Acrospirifer beaujani [sic] (Béclard, 1887); Godefroid in Godefroid et al.: 17, fig. 11.

2001a Filispirifer? beaujeani (Béclard 1887); Jansen: 271, 272, 283, 284.

2001b 'Spirifer' beaujeani Béclard, 1887; Jansen: 132, 133, $134,138$.

2008 ?Filispirifer beaujeani (Béclard, 1887); SchemmGregory: 63,65 , table 1 .

Type material. The external and internal moulds of a dorsal valve (RBINS a1254; Fig. 11K-W) illustrated by Béclard (1887, pl. 3, figs 1-2; 1896a, pl. 11, figs 3, 3a) and Vandercammen (1963, pl. 1, figs 1-6) was designated as the hololectotype [sic] (= lectotype) by Vandercammen (1963). The paralectotype (paratype in Vandercammen, 1963) corresponds to the incomplete external mould of a ventral valve figured by Béclard (1887, pl. 3, fig. 3) and Vandercammen (1963, pl. 1, fig. 10). The external and internal moulds of a ventral valve (RBINS a1930; Fig. 13G-H) considered as a paratype by Vandercammen (1963, pl. 1, figs 7-9) cannot be regarded as such as it does not be part of Béclard's (1887) original material as it was sold to the RBINS by Maillieux in 1912.

Type locality and horizon. Saint-Hubert 3 (23), Villé Formation (Siegenian; Pragian).

Description. See Béclard (1887) and Vandercammen (1963).

Remarks. Soon after its first description, the autonomy of this species was challenged by several authors notably Frech (1889) and Barrois (1889). Eventually Béclard (1896a, 1896b) considered it as a synonym of Acrospirifer primaevus (Steininger, 1853 ) as did Maillieux (1910b; 1931, see his synonymy list of Steininger's species). An opinion followed by Gourvennec (1989), who considered that the material identified and illustrated by Vandercammen (1963) as Acrospirifer beaujeani should correspond to juvenile specimens of A primaevus (Steininger, 1853), the type species of Acrospirifer Helmbrecht \& Wedekind, 1923. The species was still considered as distinct from primaevus and assigned to Acrospirifer notably by Carls in Brice et al. (2000). Careful re-examination of the type material of Béclard's species by Jansen (2001a, 2001b), very clearly revealing a capillate micro-ornamentation, led him to doubtfully assign the Belgian species to Filispirifer Jansen, 2001a (see also SchemmGregory, 2008).

From the palaeobiological viewpoint, the lectotype of $F$ ? beaujeani shows numerous epizoans (bryozoans, tabulate corals) fixed both on the external and internal faces of the dorsal valve, reflecting post-mortem encrustation and maybe also during the life of the animal. These epizoans were not illustrated by Béclard (1887) and the poor quality of Vandercammen's (1963) pictures does not allow observing them easily. In Belgium, although Lower Devonian epizoans attached to bivalves were illustrated by Maillieux (1909c), it is the first time that Lower Devonian brachiopods with epizoans are documented whereas such associations were reported in the Upper Devonian (Lecompte, 1939; Mottequin, 2008a; Mottequin et al., 2016) and especially in the Tournaisian (Mottequin \& Simon, 2017a, 2017b) successions of this country.

Current name. Filispirifer? beaujeani (Béclard, 1887).

Spirifer bisinus Le Hon, 1870

(Fig. 13I-P)

1870 Spirifer bisinus Le Hon: 497-499, pl. 11, fig. 9.

1982 Geminisulcispirifer bisinus (Le Hon, H., 1870); Sartenaer: 125-130, 149-153, table 1, pl. 1, figs 1-6, pl. 2, fig. 1 (see this author for a more complete synonymy prior 1982).

1999 Geminisulcispirifer bisinus; Godefroid \& Sartenaer in Boulvain et al.: 21-23, figs BIO6-8.

2000 Cyrtospirifer (Geminisulcispirifer) bisinus; Bultynck et al.: fig. 12 .

2006 Geminisulcispirifer bisinus (Le Hon, 1870); Johnson: 1727, fig. 1132, 2a-e (copy of Sartenaer, 1982, pl. 1, fig. 1a-e).

Type material. The specimen RBINS a2301 (Vandercammen, 1968, pl. 2, fig. 7) was selected as the lectotype by Sartenaer (1982, p. 150, pl. 1, fig 1a-e) and is fully re-illustrated herein (Fig. 13I-P). The paralectotypes RBINS a2302, a2303, and 2304 (Le Hon, 1870, pl. 11, fig. 9; Vandercammen, 1959a, pl. 4, fig. 7-10) were illustrated by Sartenaer (1982, pl. 1, fig. 2a-e, 3a-e, 5a-e) (see Sartenaer (1982) for more information related to the types).

Type locality and horizon. Givet (Fortress of Charlemont; France), Formation de Nismes, La Prée Member (early Frasnian).

Description. See Le Hon (1870), Vandercammen (1959a, 1968), and Sartenaer (1982).

Remarks. Le Hon's (1870) species is the type species of Geminisulcispirifer Sartenaer, 1982, which was described originally as a subgenus of Cyrtospirifer Nalivkin in Frederiks 1924 by Sartenaer (1982), although he did not follow the Article 6 of the Code.

Current name. Geminisulcispirifer bisinus (Le Hon, 1870).

Spirifer ferrierensis Maillieux, 1938

(Fig. 13Q-U)

1938 Spirifer (Spirifer?) ferrierensis Maillieux: 23, 41, pl. 2, fig. $5,5 \mathrm{a}$.

1941d Spirifer ferrierensis Maillieux; Maillieux: 4.

1970 Spirifer ferrierensis Maillieux, E., 1938; Vandercammen \& Vandercammen-Goffinet: 25.

Type material. The holotype (RBINS a1123; Fig. 13Q-U), which corresponds to an incomplete ventral external mould, was selected and figured by Maillieux (1938, pl. 2, fig. 5, 5a).

Type locality and horizon. Ferrières 8351, Lomme Formation (Eifelian).

Description. See Maillieux (1938).

Remarks. This species is only known by the holotype of which the poor state of preservation precludes a description. Further material is thus required to reach a better generic assignment and valuable comparison with contemporaneous species.

Current name. 'Spirifer'ferrierensis Maillieux, 1938.

Spirifer gosseleti Béclard, 1887

(Fig. 14A-X)

1887 Spirifer Gosseleti Béclard: 64, 81, pl. 4, figs 1-6. non 1895a Spirifer Gosseleti Dewalque: 36 (= Uchtospirifer? fraiponti (Dewalque, 1895b)).

1896a Spirifer Gosseleti Béclard, 1887: Béclard: 159, 165.

p 1896a Spirifer hystericus-Gosseleti [with or without a hyphen] Béclard; Béclard: 167, pl. 12, figs 1, 1a-b, 2 (copy of Béclard, 1887: pl. 4, figs 1-4), 4, 5-7, 9, non 3, 3a, 8, 10 (see Solle, 1963).

1896b Spirifer Gosseleti Béclard, 1887; Béclard: 271.

1908b Spirifer hystericus var. Gosseleti Béclard; Maillieux: 222, 223, 229.

? 1909c Spirifer hystericus var. Gosseleti; Maillieux: 196. p 1910b Spirifer excavatus Kayser; Maillieux: 194. 

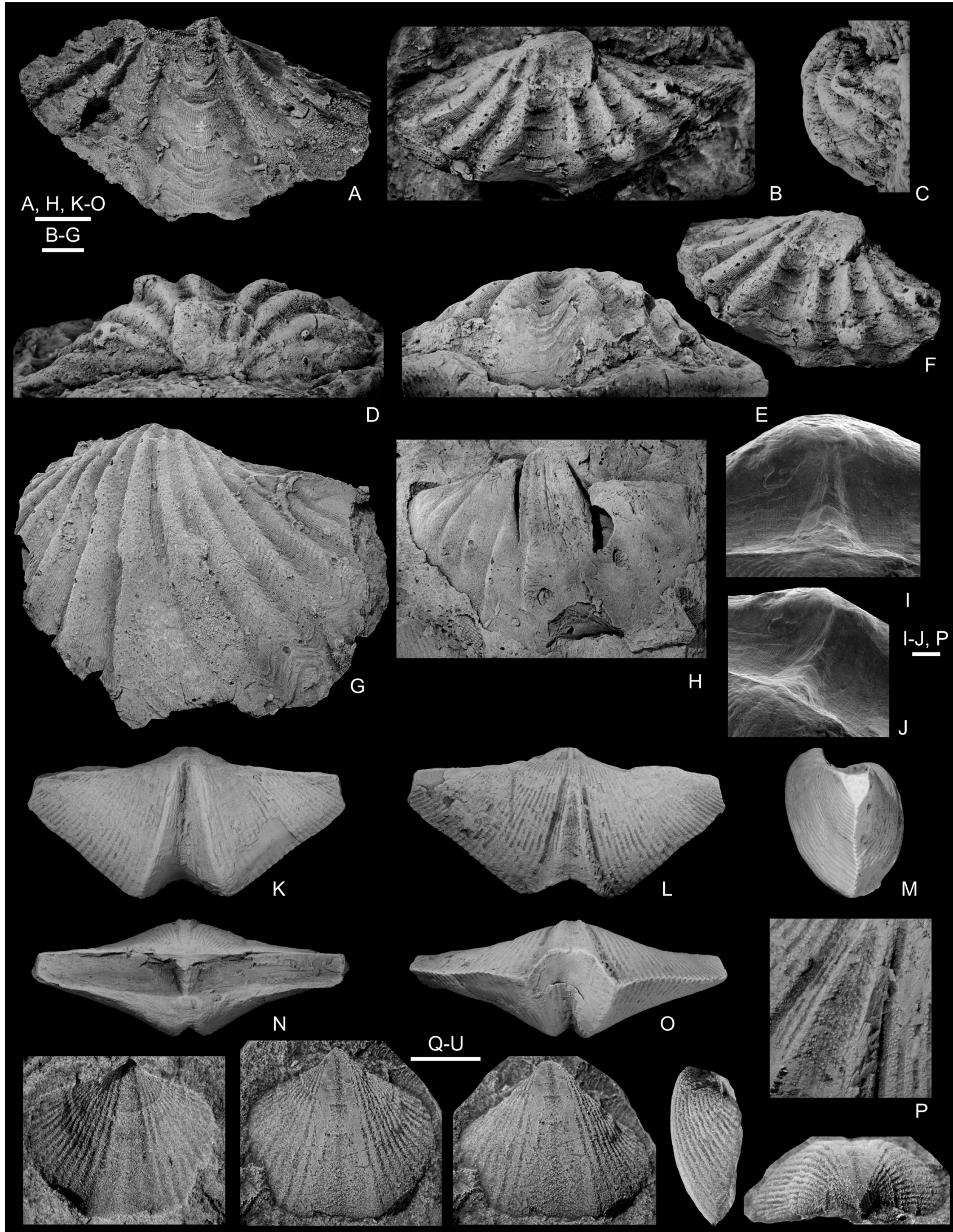

Q-U

Q
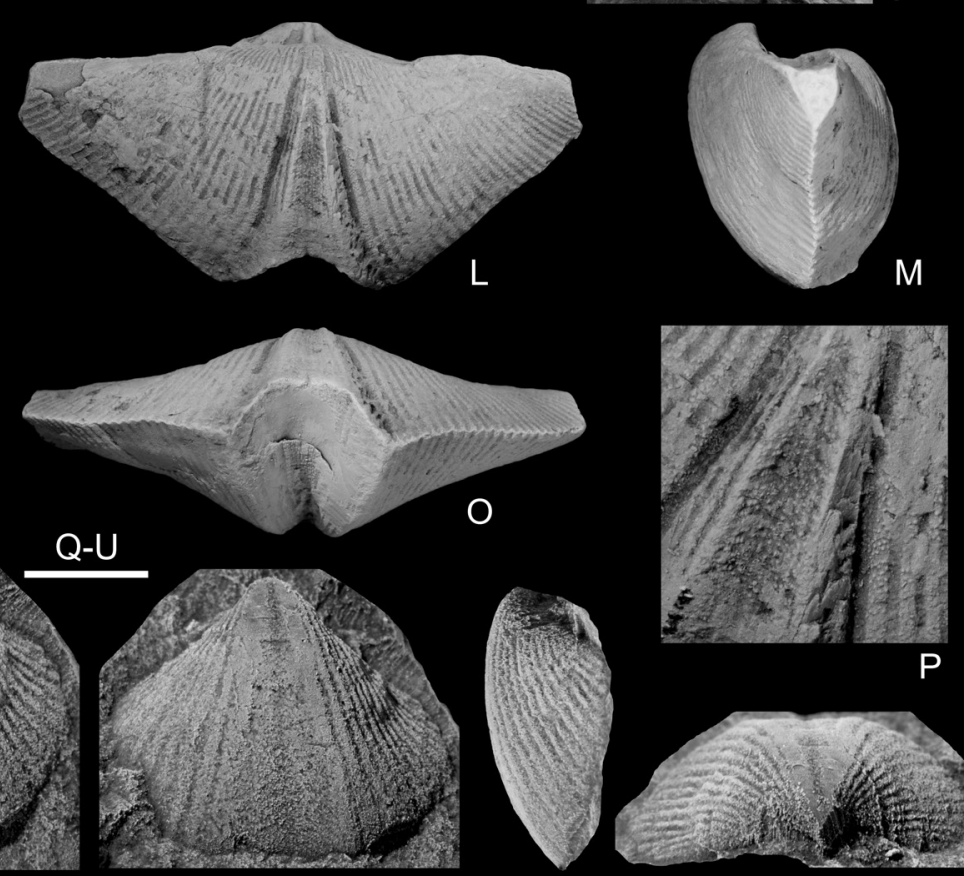

$\mathrm{P}$

Figure 13. A-H. Spirifer beaujeani Béclard, 1887 [Filispirifer? beaujeani (Béclard, 1887)]. A-F. RBINS a1255 (paralectotype), incomplete external mould of a ventral valve, and putty cast in plan, lateral, posterior, anterior, and oblique lateraloventral (partim) views; Saint-Hubert 3 (23), Villé Formation. G-H. RBINS a1930, latex cast of ventral exterior (tabulates on the right flank, close to the posterior margin), and flattened, incomplete ventral internal mould; Neufchâteau 8449, Villé Formation. I-P. Spirifer bisinus Le Hon, 1870 [Geminisulcispirifer bisinus (Le Hon, 1870)], RBINS a2301 (lectotype), close-up of the pseudodeltidium in posterior and oblique lateral views (ventral valve on top) (I-J), almost complete articulated specimen in ventral, dorsal, lateral, posterior and anterior views (K-O), and detail of the spinose microornamentation on fold and flanks (P); Givet (Fort de Charlemont), Nismes Formation (La Prée Member). Q-U. Spirifer ferrierensis Maillieux, 1938 [ 'Spirifer' ferrierensis Maillieux, 1938], RBINS a1123 (holotype), external mould of a ventral valve and plastilina cast in plan, anteroventral, lateral and posteroventral views; Ferrières 8351, Lomme Formation. Scale bars: $5 \mathrm{~mm}$ (A, B-G, K-O, Q-U), $10 \mathrm{~mm}(\mathrm{H})$ and $1 \mathrm{~mm}$ (I-J, P). 


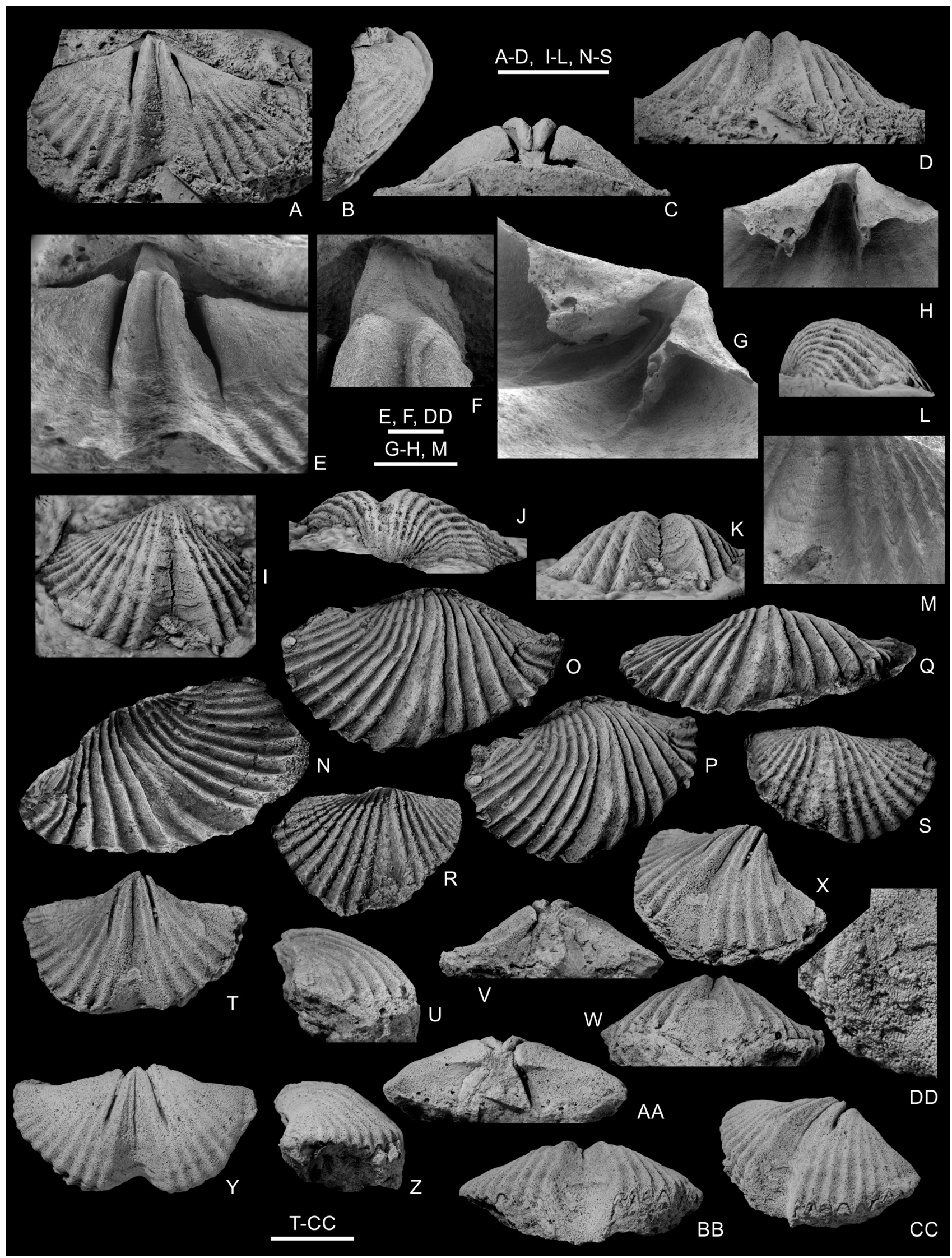

Figure 14. A-X. Spirifer gosseleti Béclard, 1887 [Mauispirifer gosseleti (Béclard, 1887)]; Saint-Hubert 3 (23), Villé Formation (A-S); Couvin 8724 Mirwart Formation (T-X). A-M. RBINS a1264 (lectotype), internal mould of a ventral valve in plan, lateral, posterior and anterior views (A-D), detail of the muscle field and of the septal pillow (E-F; SEM), latex cast of interior in lateral oblique and plan views (G-H; SEM), putty cast of exterior of ventral valve in plan, posterior, anterior and lateral views (I-L), and close-up of the external mould showing the poorly preserved microornamentation (M; SEM). N-Q. RBINS a1266 (paralectotype), oblique lateral view of external mould of a dorsal valve (M), latex cast of external mould in plan, lateral oblique, and anterodorsal views (O-Q). R-S. RBINS a1265 (paralectotype), external mould and putty cast of a dorsal valve in plan views. T-X. RBINS a1298, ventral internal mould in ventral, lateral, posterior, anterior, and oblique anterolateral views; Couvin 8724, Mirwart Formation. Y-DD. Hysterolites hystericus pachypleura Solle, 1963, RBINS a1297, ventral internal mould in ventral, lateral, posterior, anterior, and oblique anterolateral views and detail of remnants of microornament in sulcus; Couvin 8724, Mirwart Formation. Scale bars: $10 \mathrm{~mm}$ (A-D, I-L, N-S, T-CC), $2.5 \mathrm{~mm}$ (E, DD), $1 \mathrm{~mm}(\mathrm{~F}), 5 \mathrm{~mm}(\mathrm{G}-\mathrm{H}, \mathrm{M})$. 
p 1910c Spirifer hystericus Schlotheim; Maillieux: 330-332, 371, 376, non figs 1, 1a, 2-3 (copy of Béclard, 1896a, pl. 12, figs 3, $8,10)$.

p 1910c Spirifer excavatus Kayser; Maillieux: 330-332, 376, figs 4-7 (copy of Béclard, 1896a, pl. 12, figs 4-7).

non 1915 Spirifer gosseletti [sic] Vaughan: 42 (= Sphenospira julii (Dehée, 1929)).

1922b Spirifer excavatus; Maillieux: 41, fig. 18 (copy of Béclard, 1887, pl. 4, figs 1-4).

1933 Spirifer (Hysterolites) excavatus; Maillieux: 48, fig. 56a (copy of Béclard, 1887, pl. 4, figs 1-4).

1963 Spirifer gosseleti Béclard, 1887; Solle: 184-185.

p 1963 Mauispirifer gosseleti(F. Béclard); Vandercammen:24-

29, text-fig. 14, pl. 4, figs 14-19, 27.

1967 Manispirifer [sic] gosseleti; Lecompte: 42, pl. 15.

1970 Mauispirifer gosseleti (Béclard, F., 1887);

Vandercammen \& Vandercammen-Goffinet: 28-29, 75.

1982 Mauispirifer gosseleti; Godefroid \& Stainier, 142, 155,

156, tables 1, 2a.

1994 Manispirifer gosseleti (Béclard, 1887); Godefroid in

Godefroid et al.: 17, fig. 11.

2016 Mauispirifer gosseleti (Béclard, 1887); Jansen: 74, 76, 77.

Type material. The internal and external moulds of a ventral valve (RBINS a1264; Fig. 14A-M) illustrated by Béclard (1887, pl. 4, figs 1-3; 1896a, pl. 12, figs 1a-c), Maillieux (1922b, fig. 18 (ventral valve only); 1933, fig. 56a (same remark)), and Vandercammen (1963, pl. 4, figs 16-18) were selected as the type (= lectotype) by Solle (1963). The paralectotypes correspond to two external moulds of dorsal valves, namely the specimens RBINS a1265 (Fig. 14R-S) figured by Béclard (1887, pl. 4, fig. 4; 1896a, pl. 12, fig. 2), Maillieux (1922b, fig. 18 (dorsal valve only); 1933, fig. 56a (same remark)), and Vandercammen (1963, pl. 4, fig. 19), and RBINS a1266 (Fig. 14N-Q) illustrated by Béclard (1887, pl. 4, fig. 5) and Vandercammen (1963, pl. 4, figs 14-15). The internal mould of a ventral valve (RBINS a1267) figured by Béclard (1887, pl. 4, fig. 6) has not been traced. The specimen RBINS a1266 was selected as the hololectotype [sic] by Vandercammen (1963) but his publication was released in December 1963, contrary to Solle's paper that was published in April of the same year (see Jahnke, 1971).

Type locality and horizon. Saint-Hubert 3 (23), Villé Formation (Siegenian; Pragian).

Description. See Béclard (1887) and Vandercammen (1963).

Remarks. Béclard's (1887) species was assigned to the genus Mauispirifer Allan, 1947 by Vandercammen (1963) and discussed by several authors (Solle, 1963; Jahnke, 1971; Gourvennec, 1989) whose conception of the species differs (see their respective synonymy list). From this viewpoint, two ventral internal moulds (RBINS a1297 (Fig. 14Y-DD), a1298 (Fig. 14T-X)) from the Mirwart Formation (Siegenian; mostly Pragian in age), which were originally identified and illustrated as Hysterolites hystericus gosseleti by Béclard (1896a), were figured on many occasions (see below) in the Belgian literature; they are fully illustrated here. According to Solle (1963), the specimen RBINS a1297 (Béclard, 1896a, pl. 12, fig. 3-3a; Maillieux, 1910c, fig. 1; Vandercammen, 1963, pl. 4, fig. 26) belongs to Hysterolites hystericus pachypleura Solle, 1963, contrary to the specimen RBINS a1298 (Béclard, 1896a, pl. 12, fig. 4; Maillieux, 1910c, fig. 7; Vandercammen, 1963, pl. 4, fig. 27).

During one meeting of the Société géologique de Belgique (17 December 1894), Dewalque (1895a) proposed to name Spirifer gosseleti the species previously identified as $S$. orbelianus Abich, 1858 - a Famennian species from Armenia - by Gosselet (1874a, $1874 \mathrm{~b}, 1880,1888,1894)$. Two months later, also during a meeting of the same scientific society (17 February 1895), Dewalque (1895b) introduced a replacement name for $S$. gosseleti, namely $S$. fraiponti, as $S$. gosseleti Dewalque, 1895 a was preoccupied by S. gosseleti Béclard, 1887. The specimen illustrated by Gosselet (1880, pl. 4, fig. 4) is probably lost according to Brice (1988). Surprisingly, only a small part of the palaeontological community used Dewalque's (1895b) name for this emblematic species of the Givetian-Frasnian boundary in the northern France and southern Belgium. Surprisingly, Sartenaer (1974c, 1982), who examined this issue in minute detail, overlooked Dewalque's publications as did Vandercammen (1959b). Dewalque's (1895b) species should be referred probably to Uchtospirifer Liashenko, 1957 or to a related genus.

Dehée (1929) introduced Spirifer julii in order to solve the problem of secondary homonymy created by the introduction of the specific name Spirifer gosseletti [sic] by Vaughan (1915). Dehée's species is from the uppermost Famennian and referred now to Sphenospira Cooper, 1954 (see Mottequin \& Brice (2016) for the selection of the lectotype of $S$. julii).

Current name. Mauispirifer gosseleti (Béclard, 1887).

Spirifer mercurii Gosselet, 1880

(Fig. 15A-D)

1876 Spirifer hystericus Schlotheim; de Koninck: 40, pl. 1, fig. 8 .

1880 Spirifer Mercuri Gosselet: 67.

1880 Spirifer Mercurii Gosselet: pl. 1, fig. 8.

1888 Spirifer Mercurii, Goss.; Gosselet: 190.

1896b Spirifer Mercurii, Gosselet, 1880; Béclard: 274.

1910c Spirifer Mercurii Gosselet; Maillieux: 329, 371, 376.

1911 Spirifer Mercurii Gosselet; Maillieux: 176.

1912a Spirifer sulcatus, Hisinger, 1831; Leriche: 27-29, 50, pl. 1, figs 31-34.

1912b Spirifer sulcatus, Hisinger (= S. Mercurii, Gosselet)

[sic]; Leriche: 329.

1922a Spirifer sulcatus; Maillieux: 10-11.

1929 Spirifer Mercurii; Maillieux \& Demanet: table 2.

1930 Spirifer mercuri Gosselet; Asselberghs: 36-38.

1933 Spirifer (Hysterolites) Mercurii; Maillieux: 43.

1941d Hysterolites (Hysterolites) mercurii (Gosselet); Maillieux: 3.

1943b Hysterolites mercurii Gosselet; Asselberghs: 3, 12

1946 Hysterolites mercuri Gosselet; Asselberghs: 328.

1957a Howellella mercuri (Gosselet, 1880); Boucot: 315-317.

1960 Howellella mercuri (Gosselet, 1880); Boucot: 313-314, tables 2-3, pl. 16, figs 8-12.

1963 Howellella mercuri (J. Gosselet, 1880); Vandercammen:

116-119, text-figs 75-77, pl. 11, figs 9-16.

1967 Howellella mercuri; Lecompte: 29, 42, pls 5, 15.

1970 Howellella mercuri (Gosselet, J., 1880); Vandercammen

\& Vandercammen-Goffinet: 39-40, 75.

1982 Howellella mercuri (Gosselet, 1880); Godefroid: 102, 126,127 , table 3 .

1985 Howellella mercurii (Gosselet, 1880); Gourvennec: 149-154, pl. 1, figs 1-6, 9-10, 13-14, 16-19 fide Gourvennec, 1989) (see this author for a more complete synonymy before 1985).

1985 Howellella (Howellella) mercurii mercurii (Gosselet, 1880); Carls: 315, pl. 2, figs 36-37.

1989 Howellella (Howellella) mercurii (Gosselet, 1880); Gourvennec: 73-75, text-fig. 39, pl. 4, figs 7-18.

1994 Howellella mercuri (Gosselet, 1880); Godefroid: 17, fig. 11 .

1999 Howellella mercuri (Gosselet, 1880); Godefroid \& Cravatte: 9-13, 15-16, figs 3-5, pl. 3, figs 8-10.

2016 Howellella mercurii (Gosselet, 1880); Jansen: 67, 68, 69,70 , figs $3,4 b$.

Type material. Carls (1985) selected the internal mould of a ventral valve (RBINS a556; Fig. 15A-D) as the neotype; it was previously illustrated by Leriche (1912a, pl. 1, fig. 32), Boucot (1960, 16, fig. 10), and Vandercammen (1963, pl. 11, figs 13-14).

Type locality and horizon. Mondrepuis (France), Mondrepuis Formation (early Gedinnian; Lochkovian).

Description. See Boucot (1960), Vandercammen (1963), Gourvennec (1985, 1989), and Carls (1985).

Remarks. As explained by Gourvennec (1985), the correct spelling of Gosselet's species, which was assigned to Howellella Kozłowski, 1946 by Boucot (1957a), is mercurii (from genitive of Mercurius) instead of mercuri. 1880) 


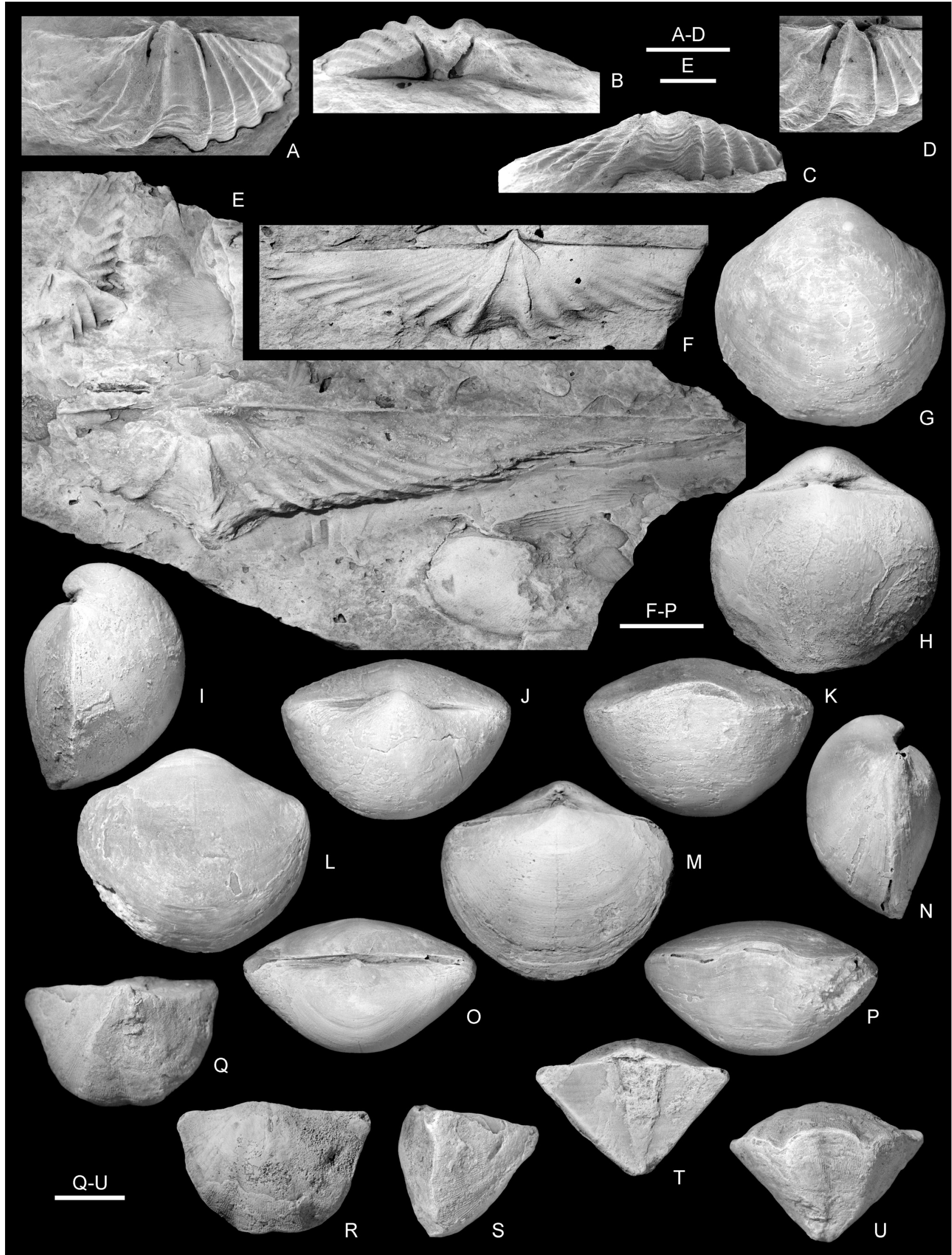

Figure 15. A-D. Spirifer mercurii Gosselet, 1880 [Howellella (Howellella) mercurii (Gosselet, 1880)], RBINS a556 (neotype), incomplete mould of a ventral valve in plan, posterior and anterior views, and detail of the median region (all SEM); Mondrepuis, Mondrepuis Formation. E-F. Spirifer paradoxus var. obliqua Asselberghs, 1913b [Euryspirifer dunensis (Kayser, 1889)]; Recogne (Les Blancs-Cailloux-Royvaux), Villé Formation. E. RBINS a3129 (lectotype), flattened, incomplete internal mould of a dorsal valve in plan view associated to a dorsal internal mould of a spiriferide and to the ventral internal mould of a chonetidine. F. RBINS a3131, flattened, incomplete internal mould of a ventral valve in plan view. G-P. Spirifer pentameroides Stainier, 1887 [Kelusia pentameroides (Stainier, 1887)]; Sombreffe 6189, Bois de Bordeaux Formation (Alvaux Member). G-K. RBINS a1848, articulated specimen in ventral, dorsal, lateral, posterior and anterior views. L-P. RBINS a1849 articulated specimen in ventral, dorsal, lateral, posterior and anterior views. Q-U. Cyrtina rigauxi Maillieux, 1909d [Acutatheca rigauxi (Maillieux, 1909d)], RBINS a9575 (lectotype), articulated specimen in ventral, dorsal, lateral, posterior and anterior views; Couvin M44 (6158B), Neuville Formation. Scale bars: 5 mm (A-D, Q-U), 10 mm (E, F-P). 
Spirifer paradoxus var. obliqua Asselberghs, 1913a (Fig. 15E-F)

1907 [no genus mentioned] Epiparadoxus Greindl: 107, unnumbered fig.

1913 Spirifer paradoxus var. obliqua Asselberghs [nomen nudum]; Asselberghs in Duvigneaud: 185 (copy of Asselberghs' (1913a) list of species).

1913a Spirifer paradoxus var. obliqua Asselberghs: 198-199, 209, figs 1 (copy of Greindl, 1907, unnumbered fig.), 2-3.

1913b Spirifer paradoxus var. obliqua Asselberghs; Asselberghs: 103, 128, pl. 3, fig. 8 .

1931 Spirifer paraxodus var. obliqua Asselberghs, 1913; Maillieux: 49, 52.

1931 Spirifer epiparaxodus Greindl, 1907; Maillieux: 49, 52. 1946 Spirifer pellico Archiac et Verneuil; Asselberghs: fig. 12 (copy of Asselberghs, 1913a, fig. 2).

p 1994 Euryspirifer dunensis (Kayser, 1889); Godefroid: 63, 70, pl. 6, fig. 11 (copy of Greindl, 1907, unnumbered fig.).

2001a Euryspirifer sp. 3; Jansen: 194, 216, 220, 221.

Type material. The incomplete dorsal internal mould (RBINS a3129; Fig. 15E), illustrated by Greindl (1907, unnumbered fig.), Asselberghs (1913a, fig. 1; 1913b, fig. 8) and Godefroid (1994, pl. 6, fig. 11), was considered as the 'échantillon type' by Asselberghs (1913b, legend of the pl. 3, fig. 8); it is designated hereby as the lectotype. The ventral internal mould (RBINS a3131; Fig. 15F) figured by Asselberghs (1913a, fig. 3) is a paralectotype whereas the second internal mould of a dorsal valve illustrated by Asselberghs (1913a, fig. 2; 1946, fig. 12) was not traced.

Type locality and horizon. Recogne (Les Blancs-CaillouxRoyvaux), Villé Formation (Siegenian; Pragian). (1994).

Description. See Asselberghs (1913a, b) and Godefroid

Remarks. Greindl (1907) figured a large, incomplete internal mould of a dorsal valve (RBINS a3129; Fig. 15E) from the Neufchâteau area under the name Epiparadoxus [sic], but without description of the specimen. Moreover, the Principle of Binomial Nomenclature (Article 5 of the Code) is not respected (see also below). Asselberghs (1913b), Maillieux (1931), and Godefroid (1994) added the genus Spirifer (between brackets or not) to the epithet epiparadoxus (see their respective discussion and list of synonymy). However, the name Spirifer epiparadoxus Greindl, 1907 as cited by these authors is not available because it does not meet the criteria of availability, especially the Articles 11.4.3 and 11.9.3 of the Code. The specimen figured by Greindl (1907) was included by Asselberghs (1913a) in his Spirifer paradoxus var. obliqua whose name first appeared in Duvigneaud (1913), but without description. According to the Article 45.6.4 of the Code, the epithet obliqua has to be considered as of subspecific rank in Asselberghs' (1913a) publication. Maillieux (1931) subsequently identified Asselberghs'restricted material as Spirifer (Acrospirifer) pellico (= Euryspirifer pellicoi (de Verneuil \& d'Archiac, 1845)) and considered that they were deformed tectonically, an opinion followed by Godefroid (1994), who transferred them to E. dunensis (Kayser, 1889). In contrast with Maillieux (1931) and Godefroid (1994), Jansen (2001a) included the specimens RBINS a3129 (see above) and a7927 (Godefroid, 1994: pl. 6, fig. 12) in E. sp. 3, but Godefroid (1994)'s opinion is provisionally followed here pending the reinvestigation of the material from the type locality. The other brachiopods observed on the lower and upper surfaces of the slab containing the lectotype clearly show signs of deformation and compaction (see Fig. 15E).

Current name. Euryspirifer dunensis (Kayser, 1889).

Spirifer pentameroides Stainier, 1887

(Fig. 15G-P)

1879 Pentamerus brevirostris Phil.; Malaise: 35

1886 Pentamerus globus, Bronn; de Lapparent: pl. 5, figs 21-22.

1887 Spirifer pentameroüdes Stainier: 75-80, text-figs A-D,

pl. 4, fig. 2a-g.

1888 Spirifer pentamerö̈des; Dormal: 96.

1892 Spirifer pentamerö̈des; Malaise \& Stainier: 297, 298.
1892 Spirifer pentameroides; Malaise: 371.

1900 Spirifer pentameroides Stainier; Scupin: 249.

1900 Spirifer pentameroides Stainier; de Dorlodot: 139.

1910d Spirifer pentameroïdes; Maillieux: 221.

1922 Spirifer pentameroides; Asselberghs in Kaisin et al.: 84.

1927 Spirifer pentameroides; Asselberghs in Asselberghs \&

Maillieux: 186.

1929 Spirifer pseudopachyrhynchus; Maillieux: 65.

1929 Spirifer pseudopachyrhynchus; Maillieux \& Demanet, table 2.

1933 Reticularia pseudopachyrhyncha (= Spirifer pentameroides Stainier) [sic]; Maillieux: 71, 76.

1936 Reticularia pseudopachyrhyncha; Asselberghs: 282, 305.

1940c Martinia pseudopachyrhyncha (Tschernyschew); Maillieux: 11, 12.

p 1941d Martinia pseudopachyrhyncha (Tschernyschew); Maillieux: 6 (only those from the Givetian).

p 1956 Emanuella volhynica A. V. Kelus, 1939; Vandercammen: 35-42, 44, text-figs 29-36, pl. 2, figs 16-32.

1959b Emanuella pentameroides (X. Stainier, 1887); Vandercammen: 4, 8, 10.

1970 Emanuella volhynica Kelus, A. von, 1939; Vandercammen \& Vandercammen-Goffinet: 72-73, 74.

2016 Diazoma pentameroides (Stainier, 1887); Mottequin \& Godefroid: 154, fig. 117G-I.

Type material. Contrary to the type material of the trilobite species Dechenella striata described by Stainier (1887) in the same publication, Stainier's figured specimens of Spirifer pentameroides have not been traced in the RBINS collections until now despite the fact that a label with Stainier's handwriting has been recovered accompanying fragments of two sectioned specimens and a poorly preserved ventral internal mould (RBINS general inventory no. 11312). Based on the available data, it is impossible to confirm (or otherwise) if these specimens can be considered as syntypes or not. Pending further research within the RBINS collections that may be conclusive, no neotype is selected, but two specimens from the type locality and closely resembling two of those illustrated by Stainier (1887) are figured here (Fig. 15G-P).

Type locality and horizon. Sombreffe 6189, Bois de Bordeaux Formation, Alvaux Member (Givetian).

Description. See Stainier (1887) and Vandercammen (1956, partim).

Remarks. As shown by the synonymy list, Stainier's (1887) species was firstly identified as a pentameride (Malaise, 1879; de Lapparent, 1886). It was then considered as a synonym of the Uralian species Spirifer pseudopachyrinchus Chernischev, 1887 notably by Scupin (1900) and Maillieux (1929, 1941d) or of the Ukrainian species Emanuella volhynica Kelus, 1939 by Vandercammen (1956), who overlooked the name proposed by Stainier (1887). Eventually Vandercammen (1959b) regarded the species pentameroides as a possible synonym of the Uralian species 'Spirifer' pachyrinchus de Verneuil in Murchison et al., 1845 that he assigned to Emanuella Grabau, 1923 in 1923-1924.

From the generic viewpoint, it is clear that Spirifer pentameroides belongs to the same genus than that of Emanuella volhynica Kelus, 1939, but this complex group of very similar and potentially synonymous species urgently needs to be reinvestigated. Furthermore, E. volhynica was selected as the type species of two genera: Diazoma Dürkoop, 1970 and Kelusia Mamedov, 1978. Mamedov's genus was rightly considered as a synonym of Diazoma Dürkoop, 1970 by Carter et al. (1994) and Johnson \& Hou (2006a). Nevertheless, Diazoma Dürkoop, 1970 (Ambocoeliidae according to Zhang \& Ma (2019)) is preoccupied by Diazoma Lamarck, 1816 (Tunicata) and Diazoma Wallengren, 1882 (Diptera) (the new name Diazosma Bergroth, 1913 was proposed for Wallengren's genus). Conformably to the Article 60 of the Code, which concerns the replacement of junior homonyms, Diazoma Dürkoop, 1970 must be rejected and replaced by a valid synonym in this case, namely Kelusia Mamedov, 1978.

Current name. Kelusia pentameroides (Stainier, 1887). 
Cyrtina rigauxi Maillieux, 1909d

(Fig. 15Q-U)

1909d Cyrtina Rigauxi Maillieux: 10-11, figs a-c.

p 1912 Cyrtyna [sic] Rigauxi; Maillieux: 41 (to be added to Mottequin, 2005b).

non 1970 Echinocoelia rigauxi (Maillieux, E., 1910); Vandercammen \& Vandercammen-Goffinet: 53-54 (=Dionacoelia secessus Mottequin, 2005b) (to be added to Mottequin, 2005b).

2005b Acutatheca rigauxi (Maillieux, 1909); Mottequin: 56-58, figs 3, 4, 9, table 1 (see this author for a more complete synonymy).

2008c Acutatheca rigauxi (Maillieux, 1909); Mottequin: 502503, fig. 61 .

Type material. The articulated specimen RBINS a9575 (Fig. 15Q-U) illustrated by line drawings in Maillieux (1909d, figs a-c) was selected as the lectotype by Mottequin (2005b, fig. 3.16).

Type locality and horizon. Couvin M44 (6158B), Neuville Formation (late Frasnian).

Description. See Maillieux (1909d) and Mottequin (2005b).

Remarks. Cyrtina rigauxi was transferred to the genus Acutatheca Stainbrook, 1945 by Mottequin (2005b), who demonstrated that this species was confused with Dionacoelia secessus Mottequin, 2005b soon after its original description. This catalogue is an opportunity to re-illustrate the holotype of D. secessus (RBINS a12111; Fig. 16A-F), which was incorrectly figured in Mottequin (2005b, fig. 5.1-5) due to an incomprehensible error that took place during the printing process of the volume no. 75 of the Bulletin des Sciences naturelles de Belgique (Sciences de la Terre).

Current name. Acutatheca rigauxi (Maillieux, 1909d).

Cyrtina undosa var. brachyptera Maillieux, 1914

(Fig. 16G-Q)

p 1912 Spirifer undosa; Maillieux: 53.

1914 Cyrtina undosa Schnur sp. var. brachyptera Maillieux: 4-6, figs 3a-b, 4a-b.

1927 Cyrtina undosa var. brachyptera Maillieux; Maillieux in Asselberghs \& Maillieux: 148.

1927 Cyrtina undosa var. brachyptera Maillieux; Van Tuijn: 162, 203, 258 .

1938 Cyrtinopsis undosa brachyptera (Maillieux); Maillieux: 23. 1941d Cyrtinopsis brachyptera (Maillieux); Maillieux: 6.

1957b Cyrtinopsis brachyptera (Maillieux); Boucot: 40, 42.

p 1963 Cyrtinopsis undosa (J. Schnur, 1851); Vandercammen:

101-104, 149, 152-153, pl. 10, figs 3-5, 6-8 (see remarks below).

1965 Cyrtinopsis brachyptera brachyptera (Maillieux, 1914);

Struve: 14-16.

1970 Cyrtinopsis undosa var. brachyptera (Maillieux, E.,

1914); Vandercammen \& Vandercammen-Goffinet: 69, 74.

p 1970 Cyrtinopsis undosa; Bultynck: 42, 43, pls 36-37.

1971 Cyrtinopsis brachyptera (Maillieux, 1914); Krans: 99.

p 1971 Cyrtinopsis undosa (Schnur, 1851); Krans: figs 2, 5.

Type material. Maillieux (1914) failed to designate a holotype for his new variety. The articulated specimen RBINS a10295 (Fig. 16G-L), illustrated by Maillieux (1914, fig. 4a-b), Vandercammen (1963, pl. 10, figs 3-5), and Krans (1971, figs $2,5)$, was designated by Vandercammen (1963, in the legend of pl. 10, figs 3-5) as the holotype of Maillieux's variety (see below) whereas the incomplete specimen RBINS a10294 (Fig. 16MQ) figured by Maillieux (1914, fig. 3a-b) was referenced as the paratype by Vandercammen (1963, in the legend of pl. 10, figs 6-8). According to the Article 74.5 of the Code, the misuse of the term 'holotype' by Vandercammen (1963) acts however as lectotype designation as this author explicitly indicated, when wrongly using the term 'holotype', that he was selecting from the type series the specimen RBINS a10295 to serve as the name-bearing type (see also Struve, 1965); the specimen RBINS a10294 is thus a paralectotype.

Type locality and horizon. Couvin 3, Jemelle Formation (Eifelian).
Description. See Maillieux (1914), Vandercammen (1963, partim), and Struve (1965).

Remarks. Conformably to the Article 45.6 .4 of the Code, the variety brachyptera erected by Maillieux (1914) has a subspecific rank, but was subsequently promoted to a specific level by Maillieux (1941d). Struve (1965) split it into several subspecies. According to Struve (1965), the species is known from Belgium, Germany and North Africa.

Two poorly preserved specimens (RBINS a10292-10293) previously identified as Cyrtinopsis undosa (Schnur, 1851) by Maillieux (1914) and Vandercammen (1963) are refigured here, pending a thorough revision of the Belgian representatives of the genus Cyrtinopsis Scupin, 1896. Struve (1965) doubtfully included the specimen RBINS a10293 (Maillieux, 1914, fig. 2a-b; Vandercammen, 1963, pl. 10, figs 9-10; Krans, 1971, fig. 3; Fig. 16R-V) in the synonymy of his new subspecies Cyrtinopsis brachyptera maillieuxi whereas the specimen RBINS a10292 (Maillieux, 1914, fig. 1; Vandercammen, 1963, text-fig. 63, pl. 10, figs 1-2; Krans, 1971, figs 1, 4; Fig. 16W$\mathrm{Y})$ was tentatively included in the synonymy of Cyrtinopsis crenata (Steininger, 1853) by Struve (1965). Struve's opinion was not followed by Krans (1971), who placed all the specimens illustrated by Maillieux (1914) and Vandercammen (1963) in C. undosa whereas he recognized the species brachyptera in the introduction of his paper (see the synonymy list above)!

Current name. Cyrtinopsis brachyptera brachyptera (Maillieux, 1914).

Spirifer verneuili var. ambosulcata Maillieux, 1930

(Fig. 17A-E)

1930 Spirifer Verneuili var. ambosulcata Maillieux: 106-108, pl. 3, fig. 2a-b.

1939 Spirifer (Cyrtospirifer) Verneuili ambosulcatus Maillieux; Maillieux: 4-5.

1941d Cyrtospirifer ambosulcatus (Maillieux); Maillieux: 4.

? 1942 Spirifer (Cyrtospirifer) verneuili Murchison var. ambosulcata Maillieux; Paeckelmann: 121-123, text-fig. 58, pl. 4 , fig. 6.

1959b Spirifer verneuili var. ambosulcata Maillieux, E., 1929 [sic]; Vandercammen: 127.

1970 Spirifer verneuili var. ambosulcata Maillieux, E., 1930; Vandercammen \& Vandercammen-Goffinet: 72, 78.

Type material. Maillieux (1930, pl. 3, fig. 2a-b) selected the specimen RBINS a10299 (Fig. 17A-E) as the type of his variety. Conformably to the Article 73.1.1 of the Code, it is the holotype of Maillieux's variety.

Type locality and horizon. Durbuy 8319a, Barvaux Formation (late Frasnian).

Description. See Maillieux (1939).

Remarks. Maillieux's variety has nothing in common with Cyrtospirifer verneuili (Murchison, 1840) in terms of outline, profile of the ventral interarea, etc. (see Brice, 1988). It was promoted to the specific level by Maillieux (1941d), an opinion not followed by Paeckelmann (1942), who still considered it as a variety of $C$. verneuili, whereas Vandercammen (1959b) regarded it as a synonym of C. grabaui (Paeckelmann, 1942). Nevertheless, it is more probable that the reverse is true as Maillieux's species has the priority, but the revision of the cyrtospiriferids from the Barvaux Formation, which were first studied by Gosselet (1894), is needed to take a decision.

Current name. Cyrtospirifer ambosulcatus (Maillieux, 1930).

Spirifer (Hysterolites) virvanus Maillieux, 1938

(Fig. 17F-I)

1938 Spirifer (Hysterolites) virvanus Maillieux: 12, 40, pl. 1, fig. $8,8 \mathrm{a}-\mathrm{b}$.

1941d Hysterolites (Hysterolites) virvanus Maillieux; Maillieux: 3.

1970 Hysterolites virvanus (Maillieux, E., 1938); Vandercammen \& Vandercammen-Goffinet: 72, 75. 


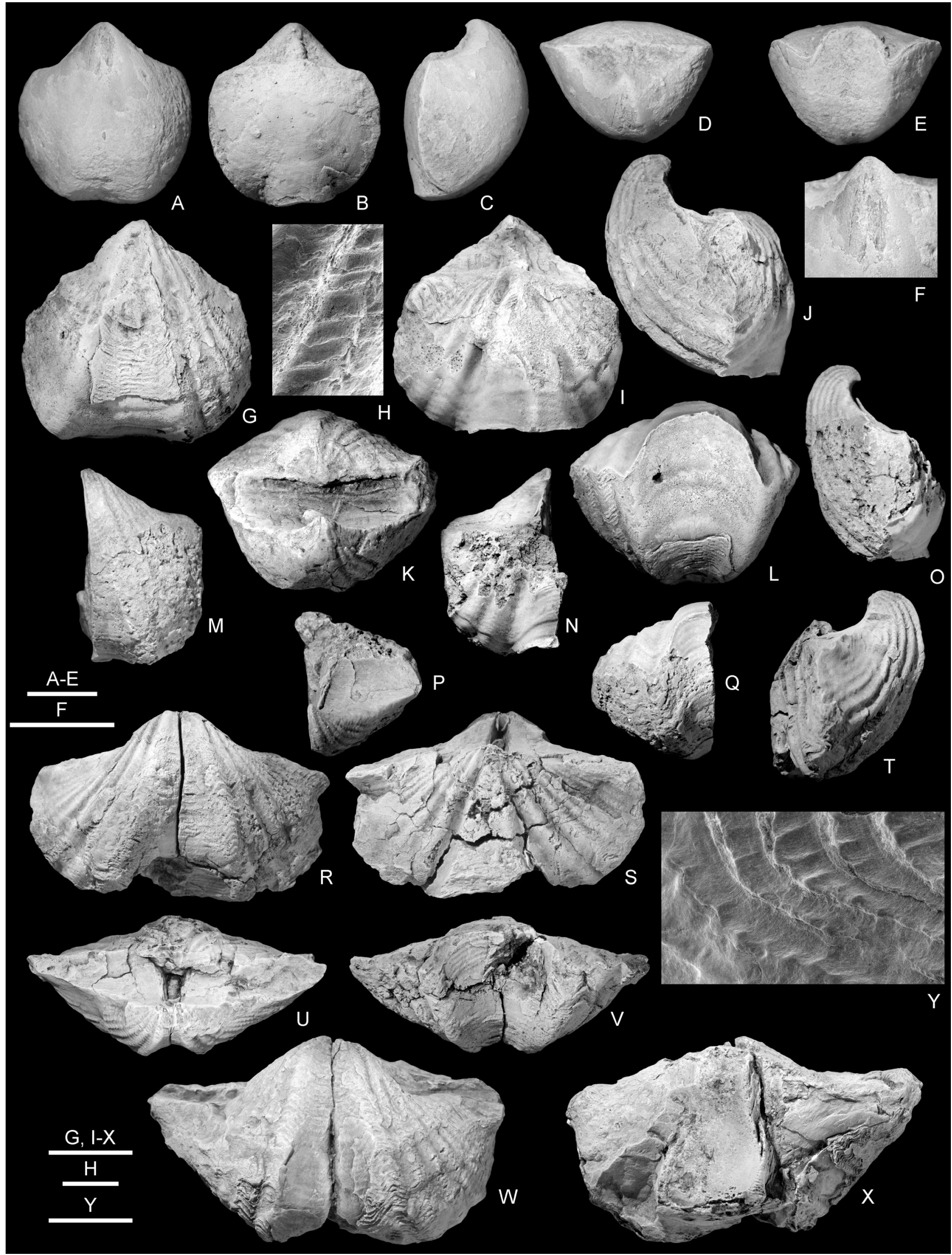

Figure 16. A-F. Dionacoelia secessus Mottequin, 2005b, RBINS a12111 (holotype), articulated specimen in ventral, dorsal, lateral, posterior and anterior views and close-up of the ventral umbo showing the slightly divergent dental plates; Boussu-en-Fagne, Moulin Liénaux Formation (Ermitage Member) G-Q. Cyrtina undosa var. brachyptera Maillieux, 1914 [Cyrtinopsis brachyptera brachyptera (Maillieux, 1914)]. G-L. RBINS a10295 (lectotype), articulated specimen in ventral, dorsal, lateral, posterior and anterior views, and close-up (SEM) of the poorly preserved microornament on the right ventral flank (H); Couvin 3, Jemelle Formation. M-Q. RBINS a10294 (paralectotype), incomplete articulated specimen in ventral, dorsal, lateral, posterior and anterior views; Couvin 11, Jemelle Formation. R-V. Cyrtinopsis brachyptera maillieuxi Struve, 1965 (?), RBINS a10293, slightly crushed articulated specimen in ventral, dorsal, lateral, posterior and anterior views; Couvin 11, Jemelle Formation. W-Y. Cyrtinopsis crenata (Steininger, 1853) (?), RBINS a10292, crushed articulated specimen in ventral and dorsal views and close-up (SEM) of the microornamentation in the sulcus. Scale bars: $5 \mathrm{~mm}(\mathrm{~A}-\mathrm{E}, \mathrm{F}), 10 \mathrm{~mm}(\mathrm{G}, \mathrm{I}-\mathrm{X}), 1 \mathrm{~mm}(\mathrm{H}, \mathrm{Y})$ 


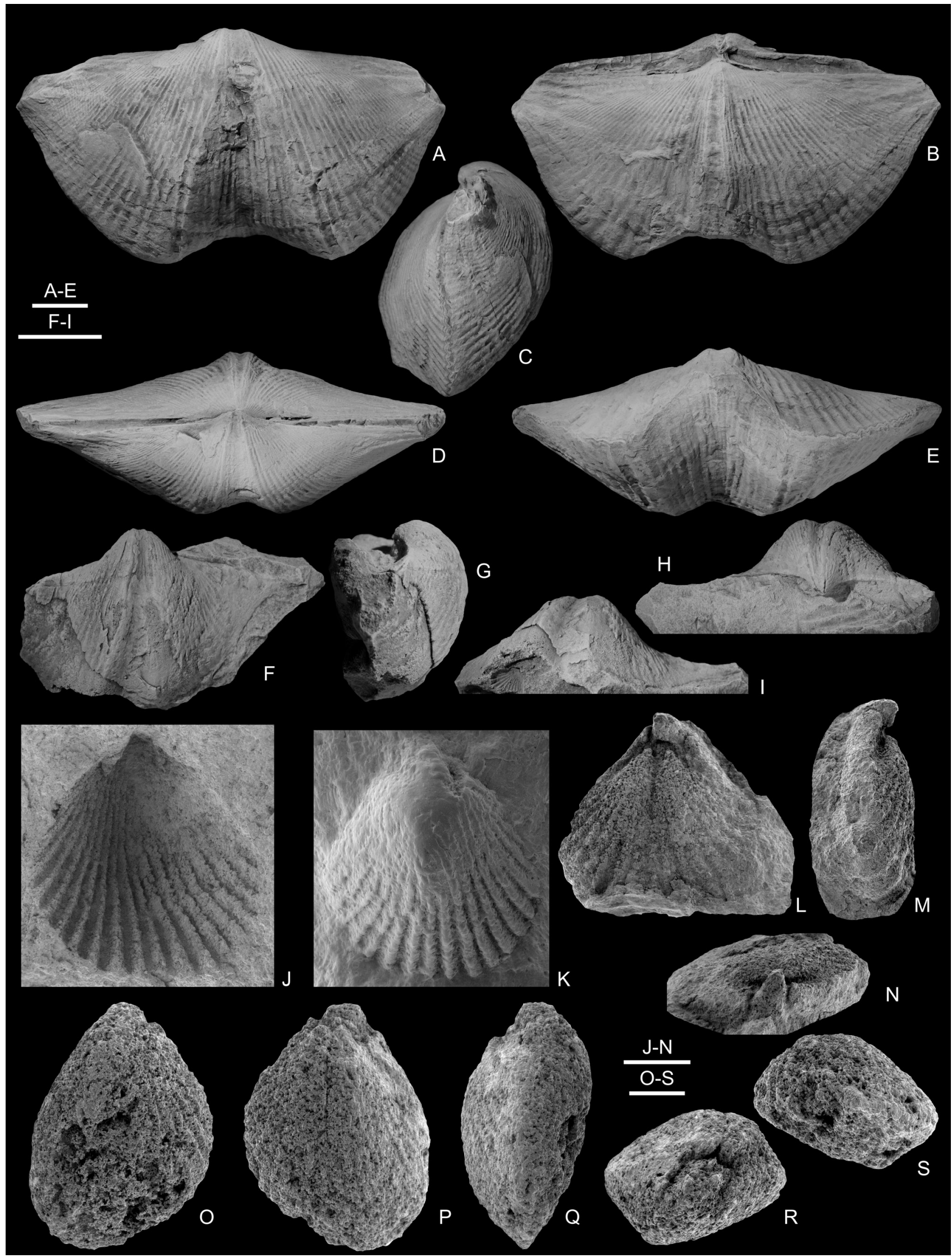

Figure 17. A-E. Spirifer verneuili var. ambosulcata Maillieux, 1930 [Cyrtospirifer ambosulcatus (Maillieux, 1930)], RBINS a10299 (holotype), slightly deformed articulated specimen in ventral, dorsal, lateral, posterior and anterior views; Durbuy 8319a, Barvaux Formation. F-I. Spirifer (Hysterolites) virvanus Maillieux, 1938 [ 'Spirifer'virvanus Maillieux, 1938], RBINS a1122 (holotype), incomplete and slightly deformed ventral valve in plan, lateral, posterior and anterior views; Treignes 8370a, Saint-Joseph Formation. J-K. Trigeria barroisi Asselberghs, 1930 [Mutationella barroisi (Asselberghs, 1930)], RBINS a3250, external mould of a ventral valve and putty cast (SEM); Malmedy 12 (Gdoumont), Marteau Formation (Waimes Member). L-S. Bathyrhyncha sp. indet., Malmedy 12 (Gdoumont), Marteau Formation (Waimes Member). L-N. RBINS a3249, articulated internal mould (with ventral valve partly included in matrix) in dorsal, lateral and posterior views (SEM). O-S. RBINS a3251, distorted and articulated internal mould in ventral, dorsal, lateral, posterior and anterior views (SEM). Scale bars: $10 \mathrm{~mm}(\mathrm{~A}-\mathrm{H}), 2 \mathrm{~mm}(\mathrm{~J}-\mathrm{N}, \mathrm{O}-\mathrm{S})$. 
Type material. Maillieux (1938, p. 40, pl. 1, fig. 8, 8a-b) selected an incomplete ventral valve (RBINS a1122; Fig. 17FI) as the holotype. He also mentioned a second valve from the locality Treignes 3 (Eau Noire Formation), which has not been traced in the RBINS collections.

Type locality and horizon. Treignes 8370a, Saint-Joseph Formation (late Emsian).

Description. See Maillieux (1938).

Remarks. Our knowledge of Maillieux's species is based on a single ventral valve of which the slightly divergent dental plates can be seen in Fig. 17F, H. It is important to stress on the fact that many specimens identified as Spinella incerta (Fuchs, 1909) by Vandercammen (1963) are from the type locality of the species virvanus; thus they should be reinvestigated as they could permit to better understand the concept of the species introduced by Maillieux (1938) and to state on its validity. Note that the German species described by Fuchs (1909) from the upper Emsian Remscheid Group in Bergisches Land was renamed Spirifer incertissimus by Godefroid et al. (2002) due to a primary homonymy issue with a Carboniferous North American species, and then selected by Mittmeyer (2008) as the type species of his new genus Incertia. The material previously identified as Spinella incerta (Fuchs, 1909) in the Siegenian and lower Emsian of southern Belgium by Godefroid (in Godefroid et al., 1994) needs to be revised.

Current name. 'Spirifer'virvanus Maillieux, 1938.

\subsection{Order Terebratulida}

Trigeria barroisi Asselberghs, 1930

(Fig. 17J-K)

1912a Rhynchonella nucula Sowerby; Leriche, 30-31, pl. 1, figs 8, 9, 11, 14, 15, 10 (?), 13 (?) fide Boucot (1960).

1929 Trigeria Barroisi Asselberghs [nomen nudum]: 758.

1930 Trigeria Barroisi Asselberghs: 43, 63, pl. 5, figs 1 (partim), 3-4, not fig. 2 (see remarks below).

1933 Trigeria Barroisi Asselberghs; Maillieux: 43.

1941b Trigeria Barroisi Asselberghs; Maillieux: 13.

1942 Trigeria Barroisi Asselberghs; Dahmer: 143-145, textfigs 35-38.

1943a Trigeria barroisi Asselberghs; Asselberghs: 10.

1943b Trigeria barroisi Asselberghs; Asselberghs: 3, 4, 7, 12. 1946 Trigeria Barroisi Asselberghs; Asselberghs: 328.

1960 Mutationella barroisi (Asselberghs, 1930); Boucot: 318-320, pl. 18, figs 1-8, tables 2, 3 .

1982 Mutationella barroisi (Asselberghs, E., 1930); Godefroid: 126, table 3 .

1986 Mutationella barroisi (Asselberghs, 1930); Rachebœuf: 137-139, text-fig. 27, pl. 21, figs 9-15.

1994 Mutationella barroisi (Asselberghs, 1930); Godefroid in Godefroid et al.: 19, fig. 13.

1999 Mutationella barroisi; Godefroid \& Cravatte: 13, table 1.

Type material. Dahmer (1942) selected the lectotype (RBINS a3248C) among the three ventral internal moulds (lectotype and two paralectotypes (RBINS a3248A, B)) illustrated by Asselberghs (1930, pl. 5, figs 1a-b; the lectotype is that on the right in both pictures). The specimens RBINS a3248A and a3248B were illustrated once more by Boucot (1960, pl. 15, fig. 6), but identified as 'Camarotoechia' sinuosa (Fuchs, 1923). Unfortunately, the slab with these three valves has not been traced yet and Boucot (1960) did not discuss his identification although he included these two paralectotypes in his synonymy of the species barroisi. The external mould of a ventral valve (RBINS a3250; Fig. 17J-K) figured by Asselberghs (1930, pl. 5, fig. 3) is a paralectotype. The internal moulds of two articulated specimens (RBINS a3249 (Fig. 17L-N, ventral valve partly embedded in matrix), a3251 (Fig. 17O-S)) illustrated by Asselberghs (1930, pl. 5, figs $2 \mathrm{a}, \mathrm{b}, 4)$, display a septalium and are assigned to an unidentified Bathyrhyncha species (juveniles?).

Type locality and horizon. Malmedy 12 (Gdoumont), Marteau Formation, Waimes Member (earliest Gedinnian; Pridoli).

Description. See Asselberghs (1930), Dahmer (1942), Boucot (1960), and Rachebœuf (1986).
Remarks. Boucot (1960) transferred this species to the meganteridid genus Mutationella Kozłowski, 1929; numerous well-preserved specimens from the Artois were figured by Rachebœuf (1986). However, it is not excluded that the specimens identified as such by Boucot (1960) has nothing in common with the lectotype selected by Dahmer (1942).

Current name. Mutationella barroisi (Asselberghs, 1930).

Cryptonella gamedellensis Maillieux, 1938

(Fig. 18A-B)

1938 Cryptonella gamedellensis Maillieux: 12, 44, pl. 1, fig. 7. 1941b Cryptonella gamedellensis Maillieux; Maillieux: 14.

Type material. A poorly preserved ventral (?) valve (RBINS a1126; Fig. 18A-B) was selected as the holotype by Maillieux (1938, pl. 1, fig. 7).

Type locality and horizon. Rochefort 31 (6), Eau Noire Formation (Emsian-Eifelian).

Description. See Maillieux (1938).

Remarks. The ornamentation, which consists of regular, conspicuously spaced growth lamellae on which several growth lines are developed, resembles that of the genus Zonathyris Struve, 1992 (see Alvarez et al., 1996). The assignment to an athyridide or a terebratulide (no trace of endopunctation visible) genus has to be confirmed on the basis of new samples from the type locality.

Current name. 'Cryptonella'gamedellensis Maillieux, 1938.

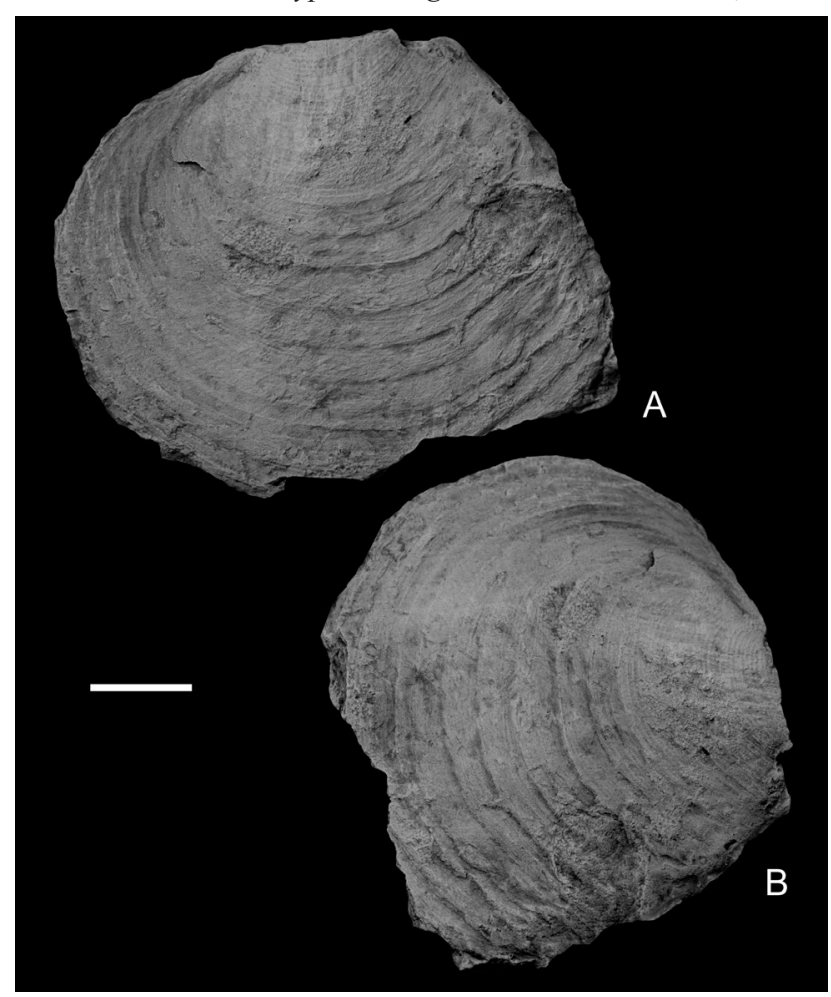

Figure 18. Cryptonella gamedellensis Maillieux, 1938 ['Cryptonella' gamedellensis Maillieux, 1938], RBINS a1126 (holotype), crushed, incomplete ventral (?) valve in plan and lateral oblique views; Rochefort 31 (6), Eau Noire Formation. Scale bar: $5 \mathrm{~mm}$.

Terebratula loxogonia Béclard, 1891

(Fig. 19A-O) 3-5.

1891 Terebratula loxogonia Béclard: 98-99, 100, pl. 3, figs

1913 Dielasma loxogonia; Maillieux: 10, 14.

1922a D. [Dielasma] loxogonia; Maillieux: 14.

1929 Dielasma loxogonia; Maillieux \& Demanet: table 2.

1933 Dielasma loxogonia; Maillieux: 66.

1938 Cryptonella loxogonia (Béclard); Maillieux: 12.

1941b Cryptonella loxogonia (Béclard); Maillieux: 14.

1965 'Terebratula' loxogonia Béclard 1891; Godefroid: pl. (unnumbered), fig. 6 . 


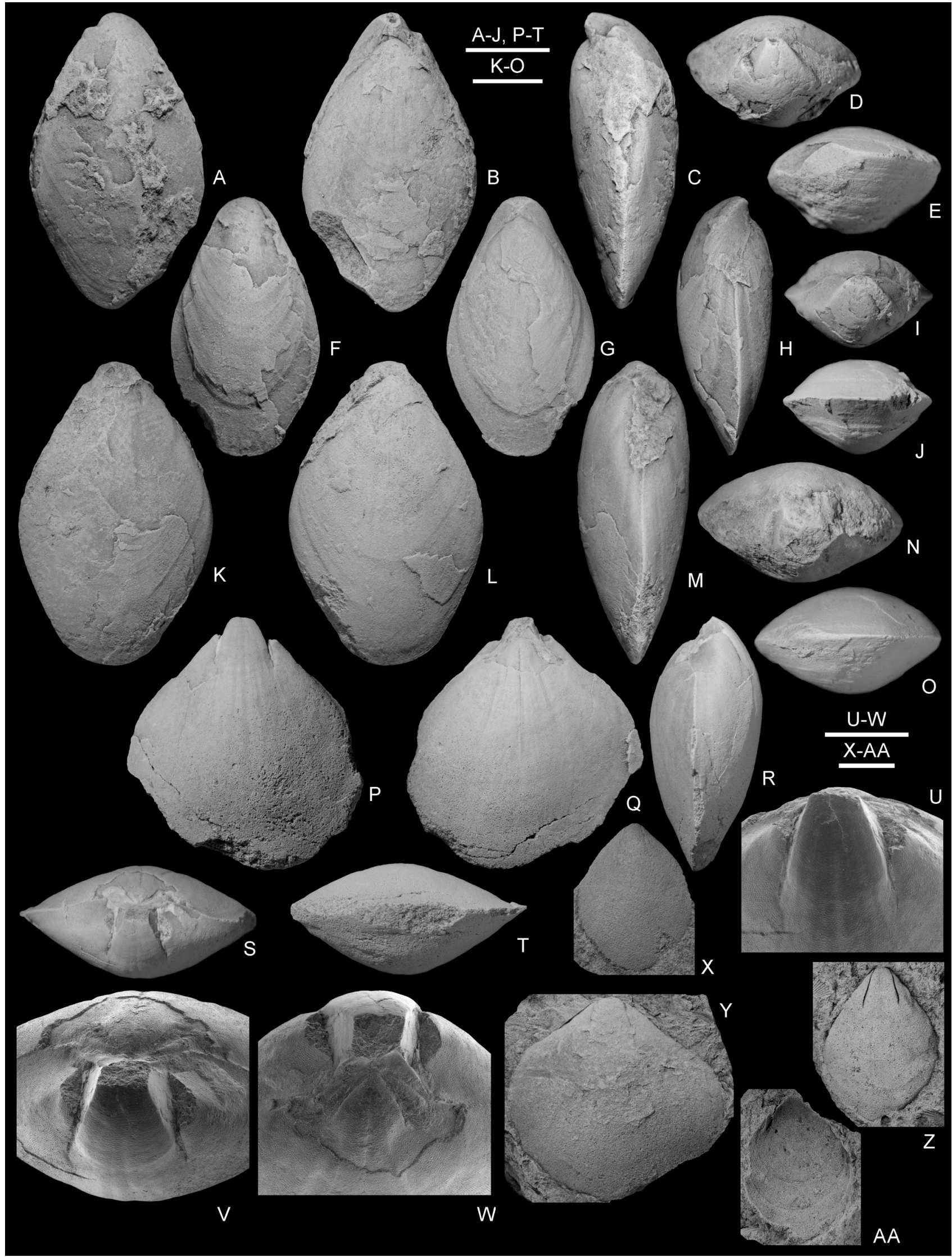

Figure 19. A-O. Terebratula loxogonia Béclard, 1891 [Cimicinella loxogonia (Béclard, 1891)]; Rochefort 8679 (2), upper part of the Saint-Joseph Formation or lower part of the Eau Noire Formation. A-E. RBINS a1693 (lectotype), articulated specimen in ventral, dorsal, lateral, posterior and anterior views. F-J. RBINS a1692 (paralectotype), articulated specimen in ventral, dorsal, lateral, posterior and anterior views. K-O. RBINS a1691 (paralectotype), articulated specimen in ventral, dorsal, lateral, posterior and anterior views. P-AA. Dielasma maillieuxi Asselberghs, 1923 [Cimicinella? maillieuxi (Asselberghs, 1923)]; Bioul (Godinne, flanks of the Godinne anticline), Rivière Formation. P-W. RBINS a3159 (lectotype), articulated internal mould in ventral, dorsal, lateral, posterior and anterior views, and close-up (SEM) of the ventral muscle field and the posterior margin (with ventral valve on top). X. RBINS a3157 (paralectotype), internal mould of a ventral valve. Y. RBINS a3158 (paralectotype), internal mould of a ventral valve. Z-AA. RBINS a3160 (paralectotype), internal and external moulds of a ventral valve. All scale bars are $5 \mathrm{~mm}$ except U-W (2.5 mm). 
1968 'Terebratula' loxogonia Béclard 1891; Godefroid: cited many times, pls $4-5,8-9$.

1970 'Terebratula' loxogonia; Bultynck: cited many times, pls 36-37.

1971 'Terebratula' loxogonia; Tsien: 123.

1979 Cimicinella loxogonia (Béclard, 1891); García-Alcalde in Arbizu et al.: 108, 110, 111, 113, text-fig. 4, pl. 2, figs 11-13.

1982 Cimicinella loxogonia; Bultynck et al.: 32, text-fig. 1.

1983 Cimicinella loxogonia; Rzhonsnitskaya: 11, table 1.

1994 Cimicinella loxogonia (Béclard, 1891); Godefroid in Godefroid et al.: 19, fig. 13 .

1999 Cimicinella loxogonia (Béclard, 1891); García-Alcalde:

173-175, figs 11, 15, 16, table 4.

2001 Cimicinella loxogonia; García-Alcalde: 124, fig. 2.

2013 Cimicinella loxogonia (Béclard, 1891); GarcíaAlcalde: 163, figs 1-2, 108, 110.5-8 (see this author for a more complete synonymy of the Spanish specimens).

Type material. García-Alcalde (1999, fig. 16.1-4) selected the articulated specimen RBINS a1693 (Béclard, 1891, pl. 3, fig. 5, 5a-b; Godefroid, 1965, pl. (unnumbered), fig. 6; Fig. 19A-E) as the lectotype. The two other specimens illustrated by Béclard (1891, pl. 3, figs 3, 3a-b, 4, 4a-4b), namely RBINS a1691 (Fig. 19K-O) and a1692 (Fig. 19F-J), were designated as the paralectotypes by García-Alcalde (1999, fig. 16.5-12).

Type locality and horizon. Rochefort 8679 (2), upper part of the Saint-Joseph Formation or lower part of the Eau Noire Formation (late Emsian) (García-Alcalde, 1999).

Description. See Béclard (1891) and García-Alcalde (1999).

Remarks. Béclard's (1891) species was assigned to Cimicinella Schmidt, 1946 by García-Alcalde in Arbizu et al. (1979) who considered the type species of Cimicinella, namely Terebratula cimex Richter \& Richter, 1918 (see Schmidt, 1946; Struve \& Werner, 1964), as a synonym of C. loxogonia. Note that the internal morphology of the Belgian specimens still remains unknown whereas the stratigraphic range of the species in the Dinant Synclinorium was detailed notably by Godefroid (1968) and Bultynck et al. (1982).

Current name. Cimicinella loxogonia (Béclard, 1891).

Dielasma maillieuxi Asselberghs, 1923

(Fig. 19P-AA)

1922 Dielasma Maillieuxi Asselberghs [nomen nudum]: B133.

1923 Dielasma Maillieuxi Asselberghs: 26-27, pl. 1, figs 11-15.

1933 Cryptonella Maillieuxi; Maillieux: 67.

1938 Cryptonella Maillieuxi (Asselberghs); Maillieux: 12.

1941b Cryptonella maillieuxi (Asselberghs); Maillieux: 14.

1951 Dielasma whidbornei (Davidson); Asselberghs: 350, $352,353$.

1955 Dielasma whidbornei (Davidson); Asselberghs: 199, 208, 210.

1977 Cimicinella maillieuxi (E. Asselberghs, 1923); Bultynck \& Boonen: 491.

Type material. Asselberghs (1923, legend of pl. 1, figs 11-15) considered the figured specimens as the types but did not select a lectotype. The articulated specimen RBINS a3159 (Asselberghs, 1923, pl. 1, fig. 14a-b; Fig. 19P-W) is hereby designated as the lectotype. The specimens RBINS a3157 (Fig. 19X), a3158 (Fig. 19Y) and a3160 (Fig. 19Z-AA), which were figured by Asselberghs (1923, pl. 1, figs 12, 13, 15a-b), are paralectotypes as is also the case of the articulated internal mould (Asselberghs, 1923, pl. 1, figs 11a-b) that has not been traced so far among the collections of either the Katholieke Universiteit Leuven, or the Université catholique de Louvain.

Type locality and horizon. Bioul (Godinne, flanks of the Godinne anticline), Rivière Formation (Eifelian).

Description. See Asselberghs (1923).

Remarks. Asselberghs (1955) regarded his species Dielasma maillieuxi as a synonym of Waldheimia whidbornei Davidson, 1882 (see Cloud, 1942) from the Middle Devonian of the Torquay area (England), as he did implicitly in 1951, whereas Bultynck \& Boonen (1977) assigned the species maillieuxi to Cimicinella Schmidt, 1946, but it needs to be confirmed.
Current name. Cimicinella? maillieuxi (Asselberghs, 1923).

Cryptonella mediocostata Maillieux, 1932

(Fig. 20A-C)

1932 Cryptonella mediocostata Maillieux: 12, 39, pl. 2, fig. 5, 5a (cited as Cryptonella medioplicata in the plate).

1933 Cryptonella mediocostata; Maillieux: 59.

1941a Cryptonella mediocostata Maillieux; Maillieux: 64. 1941b Cryptonella mediocostata Maillieux; Maillieux: 14. 1942 Cryptonella mediocostata Maillieux, 1932; Cloud: 129. 330.

1946 Cryptonella mediocostata Maillieux; Asselberghs: 248,

1994 Cryptonella mediocostata Maillieux, 1932; Godefroid in Godefroid et al.: 19, fig. 13.

Type material. The internal mould of a ventral valve (RBINS a963; Fig. 20A-C) was selected as the holotype by Maillieux (1932, pl. 2, fig. 5, 5a); it is the only known specimen of this species.

Type locality and horizon. Vireux-Molhain 2 (France), base of the Hierges Formation according to Godefroid \& Stainier (1988) (late Emsian).

Description. See Maillieux (1932).

Remarks. Contrary to what Maillieux (1932) stated, internal features can be observed easily. Long, slender dental plates circumscribe an unexcavated muscle field. The presence of low ribs near the anterior margin of sulcus is at the origin of the specific name, but additional material is required in order to revise this very poorly known species.

Current name. 'Cryptonella' mediocostata Maillieux, 1932.

Dielasma pruvosti Asselberghs, 1930

(Fig. 20D-S)

1929 Dielasma Pruvosti Asselberghs [nomen nudum]: 758.

1930 Dielasma Pruvosti Asselberghs: 35, 62, pl. 4, figs 1-3 (see remarks below).

1933 Cryptonella pruvosti; Maillieux: 43.

1941b Cryptonella pruvosti (Asselberghs); Maillieux: 14.

1943b Cryptonella pruvosti (Asselberghs); Asselberghs: 4, 12.

1946 Cryptonella pruvosti (Asselberghs); Asselberghs: 328.

Type material. The illustrated syntypes include the internal mould of a ventral valve (with external mould) (RBINS a3327; Fig. 20D-I) figured by Asselberghs (1930, pl. 4, fig. 1a-b) and an internal mould of a dorsal valve (RBINS a3228; Fig. 20J-M) illustrated by Asselberghs (1930, pl. 4, fig. 2) as well as a second dorsal internal mould (RBINS a582; Fig. 20N-S), which was figured by Asselberghs (1930, pl. 4, fig. 3) and re-illustrated by Boucot (1960, pl. 18, fig. 15), who assigned it to Protathyris? straeleni (Asselberghs, 1930).

Type locality and horizon. Florenville 1 (Muno), Mondrepuis Formation (early Gedinnian; Lochkovian).

Description. See Asselberghs (1930).

Remarks. Asselberghs' species was overlooked by Boucot (1960) and subsequent workers, most probably due to the poor state of preservation of the type material. However, it is not excluded that Asselberghs' (1930) species Dielasma pruvosti and Protathyris? straeleni are synonymous. The morphology (e.g. faint sulcus anteriorly developed, regular ornamentation, short and thin dental plates) of the ventral internal mould RBINS a3327 may suggest an assignment to Protathyris, but further material is required to reach a more confident opinion. Nevertheless, according to Principle of Priority (Article 23.1 of the Code), if the synonymy between both species is confirmed, the species pruvosti must be considered as the first described by Asselberghs (1930, page 35 vs. page 42 for straeleni). It is more cautious at this stage, pending the revision of the species pruvosti and straeleni on the basis of further and maybe better preserved material, to opt for the status quo and to not select the lectotypes of both species now.

Current name. 'Dielasma' pruvosti Asselberghs, 1930. 


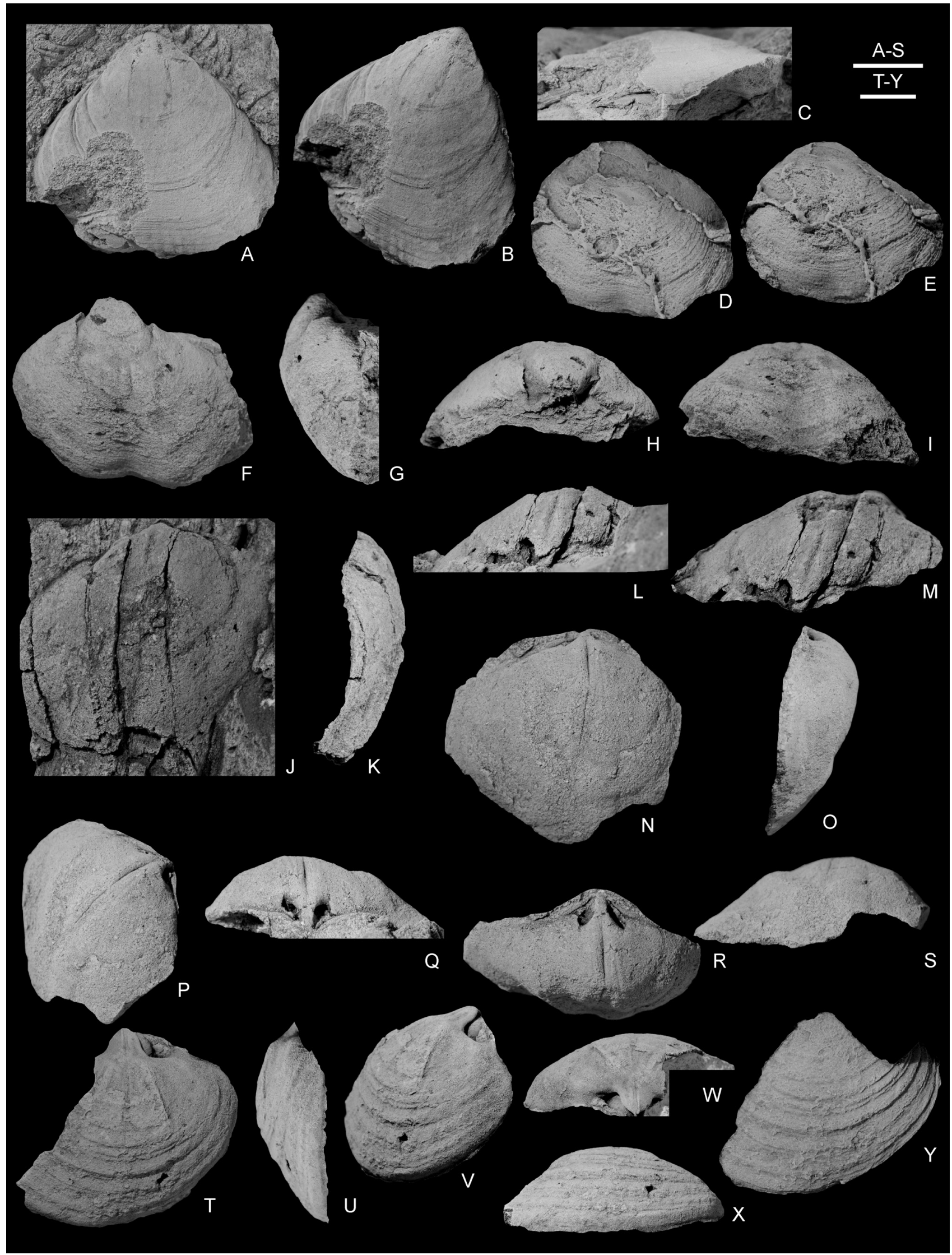

Figure 20. A-C. Cryptonella mediocostata Maillieux, 1932 [ 'Cryptonella' mediocostata Maillieux, 1932], RBINS a963 (holotype), incomplete mould of a ventral valve in plan, oblique lateral and anterior views; Vireux-Molhain 2, Hierges Formation. D-S. Dielasma pruvosti Asselberghs, 1930 ['Dielasma' pruvosti Asselberghs, 1930], syntypes illustrated by Asselberghs (1930); Florenville 1 (Muno), Mondrepuis Formation. D-I. RBINS 3227, ventral external mould in plan and anteroventral views, and ventral internal mould in plan, lateral, posterior and anterior views. J-M. RBINS a3228, dorsal internal mould in dorsal, lateral, posterior and posterodorsal views. N-S. RBINS 582 (this specimen was referred to Protathyris? straeleni by Boucot (1960)), internal mould of a dorsal valve in plan, lateral, oblique lateral, posterior, posterodorsal and anterior views. T-Y. Cryptonella rugosa Maillieux, 1931 [Monsenella? minor (Dahmer, 1931)], RBINS a927 (holotype), incomplete internal mould of a dorsal valve in plan, lateral, oblique lateral, posterior and anterior views, and putty cast of dorsal exterior; Harzé 4a, Solières Formation. All scale bars are $5 \mathrm{~mm}$. 
Cryptonella rugosa Maillieux, 1931

(Fig. 20T-Y)

1931 Cryptonella rugosa Maillieux: 7, 27-28, 86, pl. 1, fig. $12,12 \mathrm{a}$.

1936a Cryptonella rugosa Maillieux; Maillieux: 113-114.

1942 Cryptonella rugosa Maillieux, 1931; Cloud: 130.

Type material. The incomplete internal mould of a dorsal valve (with external mould) (RBINS a927; Fig. 20T-Y) was selected by Maillieux (1931, pl. 1, fig. 12, 12a) as the holotype.

Type locality and horizon. Harzé 4a, Solières Formation (Siegenian; Pragian).

Description. See Maillieux (1931).

Remarks. According to Maillieux (1936a), Cryptonella rugosa is synonymous with $C$. rhenana mut. minor Dahmer, 1931 and he reported the latter species as abundant in several Siegenian lithostratigraphic units of southern Belgium. Cloud (1942) rejected Maillieux's species from the genus Cryptonella Hall, 1861 and, more recently, García-Alcalde (2013) doubtfully referred Dahmer's species to his new cryptonellid genus Monsenella.

Current name. Monsenella? minor (Dahmer, 1931).

\section{Further comments on Silurian (Pridoli)-Devonian brachiopods firstly described in Belgium (1850-1950)}

Although the type material of the bulk of the Silurian and Devonian brachiopod species originally described in Belgium is curated now at the RBINS, that of a significant number of species is deposited in other institutions. In this chapter, we focus on those of which the type material is housed in Belgian universities (synonymy lists are provided only for the species illustrated herein); the others, which were described by de Koninck (1855), Gosselet $(1877,1887)$, and Fuchs $(1914,1923)$ are curated in foreign institutions and only listed (Table 1) in order to browse the most complete list as possible of brachiopod species. The Belgian material curated in foreign institutions and used by Grabau (1931-1933) and Paeckelmann (1942) for the erection of new varieties and species is not discussed herein.

\subsection{Order Lingulida}

Lingula amayana de Ryckholt, 1854

(Fig. 21A-C)

1854 Lingula Amayana de Ryckholt: 169-170, pl. 18, figs 10-11. 1868 Lingula Amayana de Ryckh.; Dewalque: 318. 1878 Lingula Amayana Ryckholt; Bigsby: 37.

1880 Lingula Amayana de Ryckh.; Dewalque: 358.

1881 Lingula Amayana de Ryckh.; Mourlon: 19.

? 1909a Lingula Amayana de Ryckh.; Maillieux: 138.

Type material. A partly exfoliated fragment of an indeterminate valve (ULg.PA.2018.12.23/2; Fig. 21A-C), identified as such on a green label typical of de Ryckholt's collection, has been recovered so far. It is hereby designated as the lectotype.

Type locality and horizon. Amay (with no other indication), Upper Devonian (Frasnian or Famennian).

Description. See de Ryckholt (1854).

Remarks. Maillieux (1909a) reported the presence of this species in the Frasnian of the Dinant Synclinorium, but after this report, de Ryckholt's species was not cited anymore in the Belgian literature to our knowledge. The available material does not permit to reach a better generic identification.

Current name. 'Lingula' amayana de Ryckholt, 1854.

Orbiculoidea namona de Ryckholt, 1851

1851 Orbiculö̈dea Namona de Ryckholt: 174, pl. 10, figs 13-15.

Type material. Not traced, but the Devonian material of de Ryckholt should be present in the collections of the University of Liège as it was bought by Dewalque (Dewalque, 1879; Denayer et al., 2014)

Type locality and horizon. De Ryckholt (1851) only indicated that the species is from the Devonian, but no locality is provided. According to Dewalque (1868), it is from the Famennian in all likelihood, but as explained in his Prodrome d'une description géologique de la Belgique, the Frasnian rocks were considered as belonging to the 'Famennian System' at that time. Nevertheless,

Table 1. Brachiopod species first described in Belgium but of which the type specimen (selected or not (NS)) is deposited in France (MGL: Musée Gosselet (Musée d'Histoire naturelle), Lille), Germany (MB.B.: Museum für Naturkunde (Leibniz-Institut) der Humboldt-Universität zu Berlin), and the USA (HMCZ: Harvard Museum of Comparative Zoology, Cambridge, Massachusetts). Abbreviations for the brachiopod orders: A, Athyridida; At, Atrypida; L, Lingulida; O, Orthotetida; R, Rhynchonellida; S, Spiriferida. Abbreviations for the ages: Ei, Eifelian; Fa, Famennian; Ge, 'Gedinnian’; Gi, Givetian.

\begin{tabular}{|c|c|c|c|c|}
\hline Species & Order & Age & Revision & Type \\
\hline Tenuisinurostrum crenulatum (Gosselet, 1877) & $\mathrm{R}$ & $\mathrm{Fa}$ & Sartenaer (1967) & Lectotype (MGL) \\
\hline Ptychomaletoechia dumonti (Gosselet, 1877) & $\mathrm{R}$ & $\mathrm{Fa}$ & Sartenaer (1969) & NS \\
\hline 'Lingula' gedinniana Fuchs, 1914 & $\mathrm{~L}$ & $\mathrm{Ge}$ & Nil & NS (MB.B.) \\
\hline Ptychomaletoechia gonthieri (Gosselet, 1887) & $\mathrm{R}$ & $\mathrm{Fa}$ & Sartenaer (1969) & NS \\
\hline \multirow[t]{2}{*}{ Spirifer (Quadrifarius) loculatus Fuchs, 1923} & $\mathrm{~S}$ & $\mathrm{Ge}$ & Fuchs (1929), & NS (MB.B.) \\
\hline & & & Dahmer $(1942,1951)$ & \\
\hline Pampoecilorhynchus nux (Gosselet, 1887) & $\mathrm{R}$ & $\mathrm{Fa}$ & Sartenaer (1958) & Lectotype (MGL) \\
\hline Ptychomaletoechia omaliusi (Gosselet, 1877) & $\mathrm{R}$ & $\mathrm{Fa}$ & Sartenaer (1961) & Lectotype (MGL) \\
\hline 'Rhynchonella' palmata Gosselet, 1887 & $\mathrm{R}$ & $\mathrm{Fa}$ & Nil & NS (MGL) \\
\hline Floweria pseudoelegans (Gosselet, 1877) & $\mathrm{O}$ & $\mathrm{Fa}$ & Mottequin (2008a) & NS (MGL) \\
\hline Crinisarina reticulata (Gosselet, 1877) & A & $\mathrm{Fa}$ & Mottequin (2008a) & Lectotype (MGL) \\
\hline Bathyrhyncha sinuosa Fuchs, 1923 & $\mathrm{R}$ & $\mathrm{Ge}$ & Dahmer (1942) & Lectotype (MB.B.) \\
\hline Eoparaphorhynchus triaequalis (Gosselet, 1877) & $\mathrm{R}$ & $\mathrm{Fa}$ & Sartenaer (1957) & Lectotype (MGL) \\
\hline Rugodavidsonia woodwardiana (de Koninck, 1855) & At & $\mathrm{Ei}-\mathrm{Gi}$ & Copper (1996) & Neotype (HMCZ) \\
\hline
\end{tabular}


Dewalque's assertion cannot be confirmed and an older Devonian age is not excluded.

Description. Nil.

Remarks. This species is only known by de Ryckholt's (1851) drawings, which correspond to the ventral, dorsal, and lateral (one valve!) views of one or several specimens of which the ornamentation consists of numerous filae. Although de Ryckholt (1851) did not describe his new species, it is valid conformably to the Article 12.2.7 of the Code. This species is temporarily assigned to Orbiculoidea regarding the position of the apexes and the convexity of both valves.

Current name. Orbiculoidea? namona de Ryckholt, 1851.

\section{Lingula racheneuri Leriche, 1948}

1948 Lingula Racheneuri Leriche: 293-294, pl. 1, fig. 8.

Type material. Only one of the two specimens (Mons University collections) reported by Leriche (1948) was illustrated originally. It could be selected as the lectotype.

Type locality and horizon. Wihéries, Bois d'Ausse Formation (Siegenian; Pragian). According to the stratigraphical data available (Leriche, 1948; Blieck, 2015), the species is from the Rhinopteraspis dunensis Biozone of Pragian age.

Description. See Leriche (1948).

Remarks. Leriche's (1948) material is inadequate for the erection of new species (poorly preserved specimens, internal features unknown).

Current name. 'Lingula' racheneuri Leriche, 1948.

\subsection{Order Craniida \\ Orbiculoidea cantraineana de Ryckholt, 1851}

1851 Orbicula Cantraineana de Ryckholt: 92, 99 (a footnote on page 92 indicates 'lisez [read] Orbiculoïdea').

1851 Orbiculoïdea Cantraineana de Ryckholt: 174, pl. 4, figs 1-2.

Type material. Not traced (same remark as for the species namona above).

Type locality and horizon. De Ryckholt (1851) only mentioned that his material was from the Devonian of the Luxembourg, but this could also mean Devonian of the Luxembourg province (south-eastern Belgium) and not the Grand Duchy of Luxembourg.

Description. See de Ryckholt (1851)

Remarks. De Ryckholt (1851) reported five specimens fixed on an orthoconic cephalopod; the fact that they were attached to a hard substrate by the cementation of the ventral valve suggests a possible assignment to Petrocrania or to a closely related craniide genus. The species was cited at least by the same authors than 'Lingula' amayana de Ryckholt, 1854 (see above), except Maillieux (1909a). 1851).

Current name. Petrocrania? cantraineana (de Ryckholt,
Orbiculoidea cimacensis de Ryckholt, 1851

1851 Orbicula Cimacensis de Ryckholt: 92, 99 (a footnote on page 92 indicates 'lisez [read] Orbiculoïdea').

1851 Orbiculoïdea Cimacensis de Ryckholt: 174, pl. 4, figs $3-4$.

Type material. Not traced (same remark as for the species namona above).

Type locality and horizon. De Ryckholt (1851) reported his species in the Devonian of Chimay, as reflected by the specific epithet. According to Dewalque (1868), it is from the Famennian in all likelihood, but as explained in his Prodrome d'une description géologique de la Belgique, the Frasnian rocks were considered as belonging to the 'Famennian System' at that time. Nevertheless, Dewalque's assertion cannot be confirmed and an older Devonian age cannot be ruled out.

Description. See de Ryckholt (1851).

Remarks. De Ryckholt's (1851) coloured drawings clearly show the conical dorsal valve of a craniide attached to an unidentified brachiopod characterized by numerous thin ribs. He reported the presence of radial ribs that could correspond to the simulation of the ornamentation of its host. These features suggest an assignment to Petrocrania or to a related genus. This species was cited at least by Dewalque $(1868,1880)$, Bigsby (1878), and Mourlon (1881).

Current name. Petrocrania? cimacensis (de Ryckholt, 1851).

Crania corneti Dewalque, 1881

(Fig. 21D-F)

1875 Crania Rutoti Dewalque [nomen nudum]: 135.

1881 Crania Corneti Dewalque: 51, pl. 3, fig. 3a-b.

1888 Crania Corneti Dew.; Gosselet: 415.

1936 Crania Corneti; Asselberghs: 277.

1936 Petrocrania Corneti Dewalque; Asselberghs: 312.

Type material. According to Dewalque (1881), the ventral valve (ULg.PA.2018.12.23/3; Fig. 21D-F) fixed on the dorsal valve of an atrypide (Desquamatia (Neatrypa) sp.) was the only specimen available for study, it is thus the holotype by monotypy.

Type locality and horizon. Huccorgne (Dewalque 1881; Asselberghs, 1936), Bovesse Formation (early Frasnian).

Description. See Dewalque (1881).

Remarks. Crania corneti was previously reported as C. rutoti by Dewalque (1875) in a list of brachiopod species from the Frasnian of Huccorgne (see also Asselberghs, 1936), but the specific name Crania rutoti has to be considered as nomen nudum on the basis of the Article 12 of the Code. This species is doubtfully referred to the genus Petrocrania; the dorsal valve still remains unknown.

Current name. Petrocrania? corneti (Dewalque, 1881).

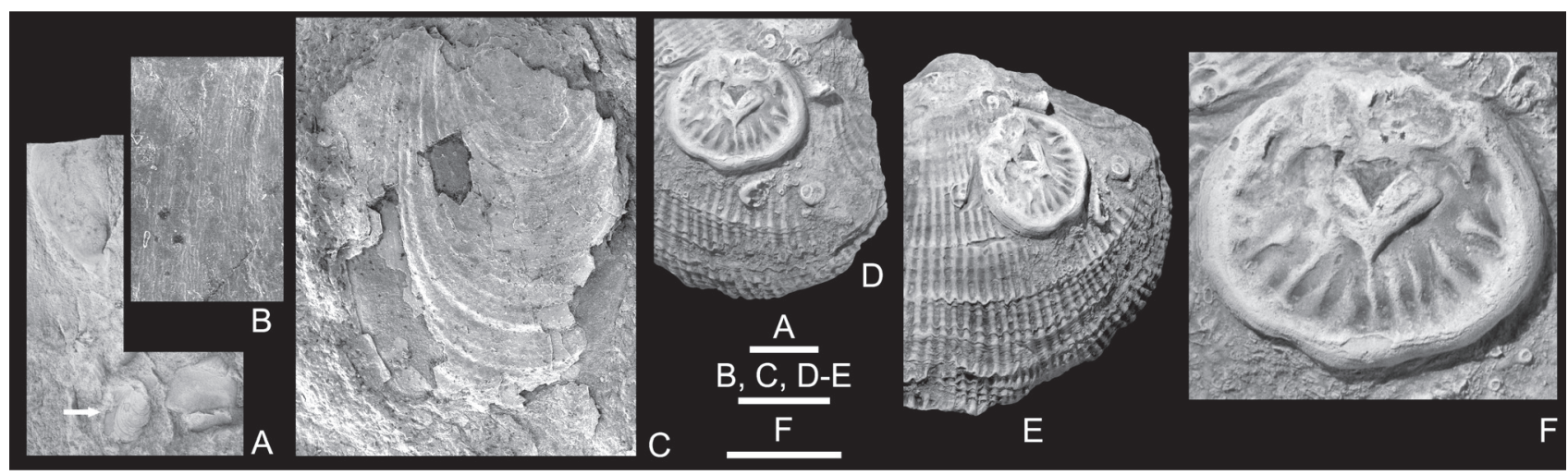

Figure 21. A-C. Lingula amayana de Ryckholt, 1854 ['Lingula' amayana de Ryckholt, 1854], ULg.PA.2018.12.23/2 (lectotype), incomplete undifferentiated valve (arrow) associated to a bivalve and a smooth rhynchonellide brachiopod (A), detail of the poorly preserved filae (B), and closeup (C); Amay, Upper Devonian shales (precise level unknown). D-F. Crania corneti Dewalque, 1881 [Petrocrania? corneti (Dewalque, 1881)], ULg. PA.2018.12.23/2 (lectotype), ventral valve (internal view) fixed on an incomplete dorsal valve of an atrypide brachiopod (Desquamatia (Neatrypa) sp.); Huccorgne, Bovesse Formation. Scale bars: A $(5 \mathrm{~mm})$, B $(0.1 \mathrm{~mm}), \mathrm{C}(1 \mathrm{~mm})$, and D-F (10 mm). 


\subsection{Order Strophomenida}

Stropheodonta dorlodoti Asselberghs, 1912

1912 Stropheodonta Dorlodoti Asselberghs: 5-6, pl. 1, figs 4-5.

Type material. Not traced until now, but it should be part of the collections of the Katholieke Universiteit Leuven or of the Université catholique de Louvain.

Type locality and horizon. Emines, Bovesse Formation (early Frasnian).

Description. See Asselberghs (1912).

Remarks. This small-sized species was assigned to the genus Douvillina by Maillieux (1940a), but based on the poor Asselberghs' pictures, it is impossible to reach a confident generic identification. This species is quite common within the Bovesse Formation according to Asselberghs (1912), who also reported it from the middle Frasnian Rhisnes Formation; Asselberghs (1936) mentioned it in both previous lithostratigraphic units and in the Franc-Waret Formation (late Frasnian).

Current name. Douvillina? dorlodoti Asselberghs, 1912.

Strophomenes rigida de Koninck, 1876

1876 Strophomenes rigida de Koninck: 35-36, 48, pl. 1, figs $5,5 \mathrm{a}$.

Type material. The line drawings of a dorsal valve of the Dewalque collection (ULg) provided by de Koninck (1876) are clearly embellished. No lectotype has been selected until now although Mottequin \& Denayer (2015, fig. 1.3) illustrated a dorsal valve relatively close to de Koninck's drawings.

Type locality and horizon. De Koninck (1876) did not indicate the origin of his new species, but it is from Gdoumont, Marteau Formation, Waimes Member (earliest Gedinnian; Pridoli).

Description. See Boucot (1960).

Remarks. Boucot (1960) assigned this species to the genus Shaleria Caster, 1939 whereas Harper \& Boucot (1978c) assigned it to their new subgenus $S$. (Protoshaleria), but the latter is considered as a synonym of the nominal subgenus by Cocks $\&$ Rong (2000). De Koninck's species was recently illustrated and discussed by Jahnke (1986), Godefroid \& Cravatte (1999) and Jansen (2014).

Current name. Shaleria (Shaleria) rigida (de Koninck, 1876).

\subsection{Order Productida/Suborder Chonetidina}

Chonetes omaliana de Koninck, 1876

1876 Chonetes Omaliana de Koninck: 34-35, 48, pl. 1, fig. 4.

Type material. Dahmer (1942) selected the ventral valve (Dewalque's collection, ULg) figured by de Koninck (1876, pl. 1, fig. 4) as the type (= lectotype, not traced).

Type locality and horizon. Gdoumont, Marteau Formation, Waimes Member (earliest Gedinnian; Pridoli).

Description. See Boucot (1960).

Remarks. The generic assignment of this abundant but still imperfectly known species needs to be revised (Rachebœuf, 1995).

Current name. 'Chonetes'omaliana de Koninck, 1876.

\subsection{Orthotetida}

Orthotetes consimilis de Koninck, 1882

1882 Orthotetes consimilis de Koninck: 523-525, fig. 3.

Type material. The ventral valve illustrated by de Koninck (1882) has not been traced yet.

Type locality and horizon. No locality is cited by de Koninck (1882), who only mentioned that his new species is found everywhere in the middle Famennian (i.e. Souverain-Pré Formation), but scarcer in the upper Famennian (see Mourlon, 1882).

Description. See de Koninck (1882).
Remarks. This poorly known, although abundant (e.g. Mourlon, 1882) orthotetide needs to be investigated according to Mottequin (2008a) and Mottequin \& Brice (2019).

Current name. 'Orthotetes' consimilis de Koninck, 1882.

\subsection{Orthida}

Orthis subvulvaria Asselberghs, 1913b

1913b Orthis subvulvaria Asselberghs: 89-93, pl. 3, figs 1-5.

Type material. Five ventral internal moulds were illustrated by Asselberghs (1913b), but no lectotype has been selected until now.

Type locality and horizon. Longlier, Villé Formation (Siegenian; Pragian).

Description. See Asselberghs (1913b).

Remarks. This species is a primary homonym of Orthis subvulvaria Maurer, 1886 (see Maillieux 1936a). Maurer's (1886) name was proposed for two internal moulds figured and identified as 'Orthis hipparionyx? Vanuxem and J. Hall' by Davidson (1865, pl. 17, figs 9, 12) from Cornwall (UK). They were later referred to Proschizophoria personata (Zeiler, 1857) notably by Drevermann (1904) and Boucot et al. (1966) whereas the species erected by Asselberghs (1913b) was assigned doubtfully to Protocortezorthis Johnson \& Talent, 1967 by Walmsley \& Boucot (1975).

Current name. Protocortezorthis? subvulvaria (Asselberghs, 1913b).

\section{Orthis verneuili de Koninck, 1876}

1876 Orthis verneuili de Koninck: 36-38, 48, pl. 1, fig. 6.

Type material. No lectotype has been selected until now and de Koninck (1876) did not precise to which collection belong the illustrated specimens. However, de Koninck (1876, p. 26, footnote no. 2) clearly indicated that the material from Mondrepuis (France) was collected by G. Dewalque (collections of the University of Liège) and C. Malaise (not yet traced in the RBINS collections). Ventral and dorsal internal moulds from the former collection were illustrated by Mottequin \& Denayer (2015, figs 5-6).

Type locality and horizon. Mondrepuis, Mondrepuis Formation (early Gedinnian; Lochkovian).

Description. See Boucot (1960) and Harper et al. (1969).

Remarks. This small orthide was assigned to Platyorthis Schuchert \& Cooper, 1931 by Boucot (1960) and re-illustrated by Godefroid \& Cravatte (1999).

Current name. Platyorthis verneuili (de Koninck, 1876).

\subsection{Order Rhynchonellida}

Rhynchonella aequicostata de Koninck, 1876

1876 Rhynchonella cequicostata de Koninck: 38-39, 48, pl. 1, fig. 7.

Type material. The lectotype has not been selected yet. As for Platyorthis verneuili (see above), de Koninck (1876) did not precise the collection to which both illustrated specimens belong. Mottequin \& Denayer (2015, fig. 1.4) figured a specimen close to that figured by de Koninck (1876, pl. 1, fig. 7).

Type locality and horizon. The material identified as such by de Koninck in Dewalque's collection is from Gdoumont, Marteau Formation, Waimes Member (earliest Gedinnian; Pridoli).

Description. See Boucot (1960).

Remarks. This imperfectly known species (see also Dahmer (1942) and Godefroid \& Cravatte (1999)) needs to be revised as is probably the case for the other rhynchonellides from the Pridoli-Lochkovian siliciclastic succession of southern Belgium. It is assigned to Bathyrhyncha. 1876).

Current name. Bathyrhyncha aequicostata (de Koninck, 


\subsection{Order Spiriferida}

Spirifer aequicostatus de Koninck, 1882

1882 Spirifer cequicostatus de Koninck: 522-523, fig. 2.

Type material. Not traced.

Type locality and horizon. Maurenne, Etrœungt Formation (latest Famennian).

Description. See de Koninck (1882).

Remarks. This species is only known by the short description of the ventral valve provided by de Koninck (1882), but it is distinct from Prospira struniana (Gosselet, 1857), which is wellknown in the uppermost Famennian of southern Belgium and northern France (Mottequin \& Brice, 2016), by its less transverse outline and the development of its sulcus.

Current name. 'Spirifer' aequicostatus de Koninck, 1882.

Spirifer dumontianus de Koninck, 1876

1876 Spirifer Dumontianus de Koninck: 39-40, pl. 1, fig. 9.

Type material. The ventral internal mould (ULg. PA.2018.12.23/4) figured by de Koninck (1876, pl. 1, fig. 9) from Dewalque's collections, which was partly photographically illustrated by Mottequin \& Denayer (2015, fig. 1.2), was selected as the type (= lectotype) by Dahmer (1942).

Type locality and horizon. Gdoumont, Marteau Formation, Waimes Member (earliest Gedinnian; Pridoli).

Description. See Asselberghs (1930), Boucot (1957a, 1960), and Vandercammen (1963).

Remarks. Asselberghs (1931) discussed the relationships existing between de Koninck's species and Spirifer (Quadrifarius) loculatus Fuchs, 1923 from Waimes, which was selected by Fuchs (1923) as the type of his new subgenus Quadrifarius (see also Fuchs, 1929): he considered that the latter species was a junior synonym of the former, an opinion followed by subsequent researchers (e.g. Dahmer, 1942; Boucot 1957a, 1960). Quadrifarius is considered as a subgenus of Delthyris Dalman, 1828 by Johnson \& Hou (2006b) or as a distinct genus (e.g. Jansen, 2016). Godefroid \& Cravatte (1999) and Jansen (2016) discussed the importance of this species for deciphering the Silurian-Devonian boundary.

Current name. Delthyris (Quadrifarius) dumontianus (de Koninck, 1876).

\section{Acknowledgments}

The author is very grateful to Julien Cillis (RBINS) who did the SEM photographic work, to Julien Denayer and Valentin Fischer (Université de Liège), who gave access to the collections of the Université de Liège, and to Jenaro García-Alcalde (Universidad de Oviedo) for fruitful discussions on the Devonian rhynchonellides from the Cantabrian Mountains. Martin Aberhan and Andreas Abele (Museum für Naturkunde Berlin), and Angela Ehling (Berlin Department of the Bundesanstalt für Geologie und Rohstoffe) are also thanked for having looked for specimens among Fuchs' material curated in their respective institution. The manuscript benefited from the thorough reviews of Andrzej Baliński (Instytut Paleobiologii PAN, Warsaw) and Ulrich Jansen (Senckenberg Forschungsinstitut und Naturmuseum, Frankfurt).

\section{References}

Abich, H., 1858. Vergleichende geologische Grundziige der Kaukasischen, Armenischen und Nordpersischen Gebirge. Prodromus einer Geologie der Kaukasischen Länder. Mémoires de l'Académie impériale de St.-Pétersbourg, 6ème série, Sciences mathématiques et physiques, 7, 361-534.

Allan, R.S., 1947. A revision of the brachiopods of the Lower Devonian strata of Reefton, New Zealand. Journal of Paleontology, 21, 436452.

Alméras, Y. \& Lathuilière, B. 1984. Paléontologie et paléoécologie de Parvirhynchia parvula (Deslongchamps), brachiopode récifal et périrécifal du Bajocien moyen. Geobios, 17, 797-822. https://doi. org/10.1016/s0016-6995(84)80122-9

Alvarez, F., Brunton, C.H.C. \& Struve, W., 1996. On Athyris (Brachiopoda) and its type species 'Terebratula' concentrica von
Buch. Senckenbergiana Lethaea, 76, 65-105. https://doi.org/10.1007/ bf03042842

Andronov, S.M., 1961. Nekotorye predstaviteli semeistva Pentameridae iz devonskikh otlozhenii okrestnostei g. Severoural'ska [Some representatives of the family Pentameridae from the Devonian deposits in the environs of the city Severouralsk]. Trudy Geologicheskogo Instituta, Akademiya Nauk SSSR, 55, 1-136. [In Russian].

Arbizu, M., García-Alcalde, J.L., García-López, S., Méndez-Bedia, I., Sánchez de Posada, L.C., Soto, F.M., Truyols, M., Truyols, J. Álvarez, F., Méndez, C. \& Menéndez, J.R., 1979. Biostratigraphical study of the Moniello Formation (Cantabrian Mountains, Asturias, NW Spain). Geologica et Palaeontologica, 13, 103-123.

Asselberghs, E., 1912. Description d'une faune frasnienne inférieure du bord nord du bassin de Namur. Bulletin de la Société belge de Géologie, de Paléontologie et d'Hydrologie, 26, Mémoires, 1-47.

Asselberghs, E., 1913a. Description des fossiles découverts par M. J. Duvigneaud aux environs de Neufchâteau. Bulletin de la Société belge de Géologie, de Paléontologie et d'Hydrologie, 26, Mémoires, 189-216.

Asselberghs, E., 1913b. Le Dévonien inférieur du bassin de l'Eifel et de l'anticlinal de Givonne dans la région sud-est de l'Ardenne belge. Mémoires de l'Institut géologique de l'Université de Louvain, 1, $1-175$.

Asselberghs, E., 1922. Notes sur le niveau fossilifère de la Grauwacke de Rouillon. Annales de la Société géologique de Belgique, 44, B130 B135.

Asselberghs, E., 1923. La faune de la Grauwacke de Rouillon (base du Dévonien moyen). Mémoires du Musée royal d'Histoire naturelle de Belgique, 33, 3-73.

Asselberghs, E., 1929. Note sur la faune marine du Gedinnien de l'Ardenne. Académie royale de Belgique, Bulletin de la Classe des Sciences, 5ème série, 15, 756-760.

Asselberghs, E., 1930. Description des faunes marines du Gedinnien de l'Ardenne. Mémoires du Musée royal d'Histoire naturelle de Belgique, 41, 1-73.

Asselberghs, E., 1931. Sur l'identité de Spirifer Dumontianus de Koninck et de Quadrifarius loculatus Fuchs. Bulletin du Musée royal d'Histoire naturelle de Belgique, 7/20, 1-2.

Asselberghs, E., 1936. Le Dévonien du bord nord du bassin de Namur. Mémoires de l'Institut géologique de l'Université de Louvain, 10, 229-327.

Asselberghs, E., 1943a. L'arkose de Weismes, le grès de Gdoumont, et leur faune (Gedinnien supérieur). Bulletin du Musée royal des Sciences naturelles de Belgique, 19/47, 1-12.

Asselberghs, E., 1943b. Les faunes du Gedinnien de 1'Ardenne. Bulletin du Musée royal d'Histoire naturelle de Belgique, 19/54, 1-15.

Asselberghs, E., 1946. L'Eodévonien de l'Ardenne et des régions voisines. Mémoires de l'Institut géologique de l'Université de Louvain, 14, $1-598$.

Asselberghs, E., 1951. Le Dévonien moyen dans la région de Harzé (bord oriental du bassin de Dinant). Bulletin de la Société belge de Géologie, de Paléontologie et d'Hydrologie, 60, 342-361.

Asselberghs, E., 1955. La Grauwacke de Rouillon (Couvinien) du bord oriental du bassin de Dinant. Mémoires de l'Institut géologique de l'Université de Louvain, 19, 176-221.

Asselberghs, E. \& Maillieux, E., 1927. Comptes rendus de la cinquième session extraordinaire de la Société géologique et minéralogique de Bretagne tenue dans le terrain dévonien de l'Ardenne, entre Charleville et Gembloux du 13 au 19 avril 1925. Bulletin de la Société géologique et minéralogique de Bretagne, 6, 117-187.

Baliński, A., 1979. Brachiopods and conodonts from the Frasnian of the Dębnik Anticline, southern Poland. Palaeontologia Polonica, 39, 3-95.

Baliński, A., 2002. Frasnian-Famennian brachiopod extinction and recovery in southern Poland. Acta Palaeontologica Polonica, 47, 289-305.

Barrois, Ch., 1889. Faune du Calcaire d'Erbray (Loire Inférieure). Contribution à l'étude du terrain dévonien de l'Ouest de la France. Mémoires de la Société géologique du Nord, 3, 1-348.

Béclard, F., 1887. Les fossiles coblenziens de Saint-Mich el. Bulletin de la Société belge de Géologie, de Paléontologie et d'Hydrologie, 1, Mémoires, 60-96.

Béclard, F., 1891. Fossiles nouveaux du Dévonien inférieur de la Belgique. Bulletin de la Société belge de Géologie, de Paléontologie et d'Hydrologie, 5, Mémoires, 96-102.

Béclard, F., 1896a. Les Spirifères du Coblenzien belge. Bulletin de la Société belge de Géologie, de Paléontologie et d'Hydrologie, 9, Mémoires, 129-240.

Béclard, F., 1896b. Catalogue synonymique et critique des Spirifères du Dévonien inférieur. Bulletin de la Société belge de Géologie, de Paléontologie et d'Hydrologie, 9, Mémoires, 260-288.

Belanger, I. \& Ghysel, P., 2017. Carte géologique de Wallonie : Bouillon - Dohan et Muno 67/1-2 et 6. 1/25 000. Namur, Service public de 
Wallonie, Direction générale de l'Agriculture, des Ressources Naturelles et de l'Environnement, avec une notice explicative de $60 \mathrm{p}$.

Belanger, I., Delaby, S., Delcambre, B., Ghysel, P., Hennebert, M., Laloux, M., Marion, J.-M., Mottequin, B. \& Pingot, J.-L., 2012. Redéfinition des unités structurales du front varisque utilisées dans le cadre de la nouvelle Carte géologique de Wallonie (Belgique). Geologica Belgica, 15, 169-175.

Bergroth, E., 1913. A new genus of Tipulidae from Turkestan, with notes on other forms. Annals and Magazine of Natural History, Series 8, 11, 575-584. https://doi.org/10.1080/00222931308693359

Béthune, P., de, 1954. Carte géologique de Belgique (échelle 1/500.000). Atlas de Belgique, planche 8. Académie royale de Belgique, Bruxelles.

Biernat, G., 1966. Middle Devonian brachiopods of the Bodzentyn Syncline (Holy Cross Mountains, Poland). Palaeontologia Polonica, 17, 1-162.

Bigsby, J.J., 1878. The flora and the fauna of the Devonian and Carboniferous periods. John Van Voorst, London, 447 p. https://doi. org/10.5962/bhl.title.121779

Blieck, A., 2015. Early Devonian heterostracans of Wihéries and Paliseul, with notes on pteraspids of La Gileppe and an acanthodian of Paliseul (Belgium). Geologica Belgica, 18, 48-65.

Blodgett, R.B., Boucot, A.J. \& Rong, J.-Y., 2002. Superfamily Gypiduloidea. In Kaesler, R.L. (ed.), Treatise on Invertebrate Paleontology, Part H, Brachiopoda, 5 (revised). Geological Society of America and University of Kansas, Boulder and Lawrence, 10051020 .

Boucot, A.J., 1957a. Revision of some Silurian and Early Devonian spiriferid genera and erection of Kozlowskiellinae, new Subfamily. Senckenbergiana lethaea, 38, 311-334.

Boucot, A.J., 1957b. A Devonian brachiopod, Cyrtinopsis, redescribed. Senckenbergiana lethaea, 38, 37-48.

Boucot, A.J., 1960. Lower Gedinnian brachiopods of Belgium. Mémoires de l'Institut géologique de l'Université de Louvain, 21, 281-324.

Boucot, A.J. \& Harper, C.W., 1968. Silurian to Lower Middle Devonian Chonetacea. Journal of Paleontology, 42, 143-176.

Boucot, A.J., Gauri, K.L. \& Johnson, J.G., 1966. New subfamily Proschizophoriinae of dalmanellid brachiopods. Paläontologische Zeitschrift, 40, 155-172. https://doi.org/10.1007/bf02988168

Boulvain, F., Bultynck, P., Coen, M., Coen-Aubert, M., Lacroix, D., Laloux, M., Casier, J.G., Dejonghe, L., Dumoulin, V., Ghysel, P., Godefroid, J., Helsen, S., Mouravieff, N.A., Sartenaer, P., Tourneur, F. \& Vanguestaine, M., 1999. Les formations du Frasnien de la Belgique. Memoirs of the geological Survey of Belgium, 44, 1-126.

Brice, D., 1981. Les Brachiopodes Pentamerida, Rhynchonellida et Terebratulida. In Morzadec, P., Paris, F. \& Rachebœuf, P.R. (eds), La tranchée de la Lézais - Emsien supérieur du Massif Armoricain. Sédimentologie, paléontologie, stratigraphie. Mémoires de la Société géologique et minéralogique de Bretagne, 24, 193-223.

Brice, D., 1986. Ordre Rhynchonellia Kuhn, 1949. In Rachebœuf, P.R. (éd.), Le Groupe de Liévin. Pridoli-Lochkovien de l'Artois (N. France). Sédimentologie-Paléontologie-Stratigraphie. Biostratigraphie du Paléozoïque, 3, 114-126.

Brice, D., 1988. Brachiopodes du Dévonien de Ferques. In Brice, D. (éd.), Le Dévonien de Ferques. Bas-Boulonnais (N. France). PaléontologieSédimentologie-Stratigraphie-Tectonique. Biostratigraphie du Paléozoïque, 7, 323-395.

Brice, D., Carls, P., Cocks, L.R.M., Copper, P., García-Alcade, J.L., Godefroid, J. \& Rachebœuf, P.R., 2000. Brachiopoda. In Bultynck, P. (ed.), Subcommission on Devonian Stratigraphy. Fossil groups important for boundary definition. Courier Forschungsinstitut Senckenberg, 220, 65-86.

Brunton, C.H.C., 2007. Orthotetida. In Selden, P.A. (ed.), Treatise on Invertebrate Paleontology, Part H, Brachiopoda, 6 (supplement). Geological Society of America and University of Kansas, Boulder and Lawrence, 2674-2677.

Brunton, C.H.C. \& Mundy, D.J.C. [with appendix by Lazarev, S.S.], 1993. Productellid and plicatiferid (productoid) brachiopods from the Lower Carboniferous of the Craven Reef Belt, North Yorkshire. British Museum (Natural History), Bulletin (Geology), 49, 99-119.

Buckman, S.S., 1918. The Brachiopoda of the Namyau Beds, Northern Shan States, Burma. Memoirs of the Geological Survey of India, Palaeontologia Indica (new series), 3/2, 1-299. [Published for 1917].

Bultynck, P., 1965. Contribution à l'étude des corrélations stratigraphiques entre le Massif Schisto-Rhénan et l'Ardenne - Etude d'une faunule à conodontes dans un petit bioherme du Couvinien Supérieur à Couvin. Annales de la Société géologique de Belgique, 88, B61-B72.

Bultynck, P., 1970. Révision stratigraphique et paléontologique de la coupe type du Couvinien. Mémoires de l'Institut géologique de l'Université de Louvain, 26, 1-152.

Bultynck, P. \& Boonen, P., 1977. Conodontes des formations de Rouillon, de Claminforge et de Nèvremont - Mésodévonien du bord nord du Synclinorium de Dinant. Annales de la Société géologique de Belgique, 99, 481-509. [Published for 1976].

Bultynck, P. \& Dejonghe, L., 2002. Devonian lithostratigraphic units (Belgium). Geologica Belgica, 4, 39-69.

Bultynck, P., Godefroid, J. \& Sartenaer, P., 1982. Brakhiopody I konodonty pogranitschnykh Ems-Kouvenskikh otlojenii Belgiisckikh Ardenn [Brachiopods and conodonts from beds near the Emsian/Couvinian boundary in the Belgian Ardennes]. In Sokolov, B.S. \& Rzhonsnitskaya, M.A., (eds), Biostratigrafia pogranitschnykh otlojenii nijnego i srednego devona. Trudy polevoi sessii mejdounarodnoi podkomisii po stratigrafii devona, Samarkand 1978 [Biostratigraphy of Lower and Middle Devonian boundary deposits. Proceedings of Field Symposium of the International Subcommission on the Devonian Stratigraphy, Samarkand 1978]. Academiya Nauk SSSR, Leningrad, 31-37.

Bultynck, P., Coen-Aubert, M., Dejonghe, L., Godefroid, J., Hance, L. Lacroix, D., Préat, A., Stainier, P., Steemans, P., Streel, M. \& Tourneur, F., 1991. Les formations du Dévonien moyen de la Belgique. Mémoires pour servir à l'Explication des Cartes Géologiques et Minières de la Belgique, 30, 1-105.

Bultynck, P., Coen-Aubert, M. \& Godefroid, J., 2000. Summary of the state of correlation in the Devonian of the Ardennes (BelgiumNE France) resulting from the decisions of the SDS. Courier Forschungsinstitut Senckenberg, 225, 91-114.

Carls, P., 1974. Die Proschizophoriinae (Brachiopoda; Silurium-Devon) der Ostlichen Iberischen Ketten (Spanien). Senckenbergiana lethaea, $55,153-227$.

Carls, P., 1985. Howellella (Hysterohowellella) knetschi (Brachiopoda, Spiriferacea) aus dem tiefen Unter-Gedinnium Keltiberiens. Senckenbergiana lethaea, 65, 297-326.

Carls, P., Slavík, L. \& Valenzuela-Ríos, J.I., 2008. Comments on the GSSP for the basal Emsian stage boundary: the need for its redefinition. Bulletin of Geosciences, 83, 383-390.

Carter, J.L., Johnson, J.G., Gourvennec, R. \& Hou, H.-F., 1994. A revised classification of the spiriferid brachiopods. Annals of Carnegie Museum, 63, 327-374.

Caster, K.E., 1939. A Devonian fauna from Colombia. Bulletin of American Paleontology, 24, 1-218.

Chernyshev [Chernyschev], T. N., 1887. Des mittleren und oberen Devon am West-Abhange des Urals. Mémoires du Comité Géologique, 3/3, $1-208$.

Cloud, P.E. Jr., 1942. Terebratuloid Brachiopoda of the Silurian and Devonian. Geological Society of America Special Paper, 38, 1-182. https://doi.org/10.1130/SPE38-pxi

Cocks, L.R.M. \& Rong, J.-Y., 2000. Order Strophomenida. In Kaesler, R.L. (ed.), Treatise on Invertebrate Paleontology, Part H, Brachiopoda, 5 (revised). Boulder and Lawrence, Geological Society of America and University of Kansas, 216-348.

Conil, R., Dreesen, R., Lentz, M.-A., Lys, M. \& Plodowski, G., 1986. The Devono-Carboniferous transition in the Franco-Belgian Basin with reference to Foraminifera and Brachiopods. Annales de la Société géologique de Belgique, 109, 19-26.

Cooper, G.A., 1954. Unusual Devonian brachiopods. Journal of Paleontology, 28, 325-332.

Cooper, G.A. \& Dutro, J.T., Jr., 1982. Devonian Brachiopods of New Mexico. Bulletins of American Paleontology, 82-83, 1-215.

Cooper, G.A. \& Muir-Wood, H.M., 1951. Brachiopod homonyms. Journal of the Washington Academy of Sciences, 41, 195-196.

Copper, P., 1981. Les Brachiopodes Atrypida. In Morzadec, P., Paris, F. \& Rachebœuf, P.R. (eds), La tranchée de la Lézais - Emsien supérieur du Massif Armoricain. Sédimentologie, paléontologie, stratigraphie. Mémoires de la Société géologique et minéralogique de Bretagne, 24, 225-229.

Copper, P., 1996. Davidsonia and Rugodavidsonia (new genus), cryptic Devonian atrypid brachiopods from Europe and South China Journal of Paleontology, 70, 588-602. https://doi.org/10.1017/ s0022336000023556

Copper, P. \& Rachebœuf, R., 1985. Devonian atrypoid brachiopods from the Armorican Massif, northwestern France. Palaeontographica, Abteilung A, 187/1-3, 58-104.

Dahmer, G., 1923. Die Fauna der oberdevonischen Koblenzschichten am Nordwestrand der Dillmulde. Jahrbuch der Preussischen Geologischen Landesanstalt, 42, 655-693.

Dahmer, G., 1931. Fauna der belgischen 'Quartzophyllades de Longlier' in Siegener Rauhflaserschichten auf Blatt Neuwied. Jahrbuch der Preussischen Geologischen Landesanstalt, 52, 86-111.

Dahmer, G., 1942. Die Fauna der 'Gedinne' - Schichten von Weismes in der Nordwest-Eifel (mit Ausschluss der Anthozoen und Trilobiten). Senckenbergiana, 25, 111-156.

Dahmer, G., 1951. Die fauna der nach-ordovizischen Glieder der Verseschichten. Mit Aussschluß der Trilobiten, Crinoiden und Anthozoen. Palaeontographica, Abteilung A, 101/1-4, 1-152. 
Dalman, J.W., 1828. Uppställning och Beskrifning af de i Sverige funne Terebratuliter. Kongliga Svenska Vetenskapsakademien Handlingar for $1827,85-155$.

Davidson, T., 1865. A Monograph of British Devonian Brachiopoda. Part 6 (second portion). Palaeontographical Society Monograph, 17, 57-131. https://doi.org/10.1080/02693445.1865.12027937

Davidson, T., 1882. A Monograph of the British fossil Brachiopoda, Devonian and Silurian Supplements, vol. 5, part 1. Palaeontographical Society Monograph, 36, 1-134. https://doi.org/10.1080/02693445.18 82.12027975

Dehée, R., 1929. Description de la faune d'Etrœungt - Faune de passage du Dévonien au Carbonifère. Mémoires de la Société géologique de France, nouvelle série, 5, 1-62.

Denayer, J., Fischer, V. \& Mottequin, B., 2014. Rediscovery of the forgotten de Ryckholt Collection (gastropods, bivalves, worms; Late Cretaceous, Belgium). Cretaceous Research, 47, 66-71. https://doi. org/10.1016/j.cretres.2013.10.002

Dewalque, G., 1868. Prodrome d'une description géologique de la Belgique. Libraire polytechnique De Decq, Bruxelles and Liège, $442 \mathrm{p}$.

Dewalque, G., 1875. Compte-rendu à Statte, Moha, Huccorgne et Fallais. Annales de la Société géologique de Belgique, 2, Bulletins, 128-146.

Dewalque, G., 1879. Revue des fossiles landeniens décrits par de Ryckholt. Annales de la Société géologique de Belgique, 6, 156-167.

Dewalque, G., 1880. Prodrome d'une description géologique de la Belgique. Seconde édition, conforme à la première. H. Manceaux, Bruxelles, $501 \mathrm{p}$.

Dewalque, G., 1881. Fragments paléontologiques : sur une algue nouvelle de la craie ; une algue nouvelle des psammites du Condroz; un nouveau crustacé phyllopode ; Leperdita Briarti ; Crania Corneti ; Protaster Descheni. Annales de la Société géologique de Belgique, 8, Mémoires, 43-54.

Dewalque, G., 1895a. Le Cryphaeus de Hotton (Frasnien), désigné sous le nom de $C$. arachnoides est une nouvelle espèce qu'il appelle C. Valleeanus et le Spirifer de cette localité connu sous le nom de $S$. Orbelianus est également une nouvelle espèce, qu'il appelle S. Gosseleti. Annales de la Société géologique de Belgique, 22, Bulletin, 36.

Dewalque, G., 1895b. Le Spirifer qu'il avait nommé Sp. Gosseleti dans la séance du 17 décembre 1894, doit être appelé Sp. Fraiponti. Annales de la Société géologique de Belgique, 22, Bulletin, 46.

Dorlodot, H. de, 1900. Compte rendu des excursions sur les deux flancs de la crête du Condroz faites par la Société belge de Géologie, de Paléontologie et d'Hydrologie le 19 mars et les 8 et 9 avril 1899. Bulletin de la Société belge de Géologie, de Paléontologie et d'Hydrologie, 19, Mémoires, 113-192.

Dormal, V., 1888. Contribution à l'étude du système dévonien dans le bassin de Namur. Annales de la Société géologique de Belgique, 15, Mémoires, 88-111.

Drevermann, F., 1904. Die Fauna der Siegener Schichten von Seifen unweit Dierdorf (Westerwald). Palaeontographica, 50, 229-287.

Drot, J., 1975. Orthida (Brachiopodes) du Maroc présaharien. I. Orthidina. II. Dalmanellidina du Dévonien inférieur à l'exclusion du genre Schizophoria. Annales de Paléontologie, 61, 45-99.

Dürkoop, A., 1970. Brachiopoden aus dem Silur, Devon und Karbon in Afghanistan (Mit einer Stratigraphie des Paleozoikum der Daschte-Nawar/Ost und Von Rukh). Palaeontographica, Abteilung A, 134, $153-225$.

Duvigneaud, J., 1913. L'âge des couches de Royvaux. Bulletin de la Société belge de Géologie, de Paléontologie et d'Hydrologie, 26, Mémoires, 159-187.

Eudes-Deslongchamps, E., 1862. Études critiques sur des Brachiopodes nouveaux ou peu connus. Article 2 : Espèces du Système Oolithique inférieur. Bulletin de la Société linéenne de Normandie, 3ème série, 7, 274-279.

Frech, F., 1889. Ueber das rheinische Unterdevon und die Stellung des 'Hercyn'. Zeitschrift der Deutschen geologischen Gesellschaft, 41, $175-287$.

Frederiks, G.N., 1924. Paleontologicheskye etiudy. 2. O VerkhneKamennougol'nykh spiriferdakh Urala [Paleontological studies. 2. On Upper Carboniferous spiriferids from the Urals]. Geologicheskogo Komiteta, Izvestiya 38, 295-324. [In Russian; volume 38 for 1919 was published in 1924].

Fuchs, A., 1909. Die Brachiopoden und Gasteropoden der Remscheider Schichten. In Spriestersbach, J. \& Fuchs, A., Die Fauna der Remscheider Schichten. Abhandlungen der Königlich Preussischen Geologischen Landesanstalt, Neue Folge, 58, 53-81.

Fuchs, A., 1914. Einige neue oder weniger bekannte Molluskoiden und Mollusken aus deutschem Devon. Jahrbuch der Königlich Preussischen Geologischen Landesanstalt, 33/2 (for 2012), 49-76.

Fuchs, A., 1919. Beitrag zur Kenntnis der Devonfauna der Verse- und der Hobräcker Schichten des sauerländischen Faciesgebietes. Jahrbuch der Preussischen Geologischen Landesanstalt, 39, 58-95.
Fuchs, A., 1923. Über die Beziehungen des sauerländischen Faciesgebietes zur Belgischen Nord- und Südfacies und ihre Bedeutung für das Alter des Verseschichten. Jahrbuch der Preussischen Geologischen Landesanstalt, 42, 839-859.

Fuchs, A., 1929. Beitrag zur Kenntnis der unteren Gedinnefauna. Jahrbuch der Preussischen Geologischen Landesanstalt, 50, 194-201.

Fuchs, A., 1934. Über eine untere Gedinnefauna im Ebbesandstein des Ebbegebirges. Zeitschrift der Deutschen Geologischen Gesellschaft, 86, 395-409.

García-Alcalde, J.L., 1973. Braquipodos Devonicos de la Cordillera Cantabrica. 7) Familia Leptostrophiidae Caster, 1939 (Strophomenidina). Parte 2 (y última). Breviora Geológica Astúrica, 17/3, 43-48.

García-Alcalde, J.L., 1999. Terebratúlidos (Braquiópodos) del Emsiense superior de Colle (Sabero, León, N. de España). Trabajos de Geología, Universidad de Oviedo, volumen homenaje a J. Truyóls, 21, 159-176.

García-Alcalde, J.L., 2001. Paleobiogeographical relationships between North Gondwana and South Baltica: The Ivanothyris havliceki fauna (Cantabrian Zone, latest Emsian). Journal of the Czech Geological Society, 46, 121-130.

García-Alcalde, J.L., 2013. Terebratúlidos (braquiópodos) del Devónico de la Cordillera Cantábrica ( $\mathrm{N}$ de España). Trabajos de Geología, Universidad de Oviedo, 33, 17-170.

García-Alcalde, J.L., 2015. La sucesión del Emsiense más alto-Eifeliense basal (Devónico) en el Dominio Astur-Leonés de la Zona Cantábrica (N de España) y su fauna de braquiópodos. Trabajos de Geología, Universidad de Oviedo, 35, 41-98. https://doi.org/10.17811/ tdg.35.2015.41-99

Godefroid, J., 1965. Contribution à l'étude des corrélations du Couvinien dans l'Ardenne et l'Eifel. Annales de la Société géologique de Belgique, 88, B73-B92.

Godefroid, J., 1968. Contribution à l'étude du Couvinien entre Wellin et Jemelle (bord sud du bassin de Dinant). Académie royale de Belgique, Classe des Sciences, Mémoires, collection in-4 $4^{\circ}$, 2ème série, 17/3, $1-87$

Godefroid, J., 1971. Morphologie interne de Gypidulinae couviniens. Annales de la Société géologique de Belgique, 94, 45-71.

Godefroid, J., 1974. Les Gypidulinae des niveaux récifaux du Frasnien de Frasnes et de Boussu-en-Fagne. Bulletin de l'Institut royal des Sciences naturelles de Belgique, Sciences de la Terre, 50/9, 1-65.

Godefroid, J., 1979. Redescription de Gypidula typicalis Amsden, T. W., 1953, espèce-type du genre Gypidula Hall, J., 1867. Bulletin de l'Institut royal des Sciences naturelles de Belgique, Sciences de la Terre, 51/11, 1-26.

Godefroid, J., 1982. Gedinnian lithostratigraphy and biostratigraphy of Belgium. Historical subdivisions and brachiopod biostratigraphy. A synopsis. Courier Forschungsinstitut Senckenberg, 55, 97-134.

Godefroid, J., 1994. Le genre Euryspirifer Wedekind, 1926 (Brachiopoda, Spiriferida) dans le Dévonien inférieur de la Belgique. Bulletin de l'Institut royal des Sciences naturelles de Belgique, Sciences de la Terre, 64, 57-83.

Godefroid, J., 1995a. Daya shirleyi Alvarez \& Rachebœuf, 1986, un brachiopode silurien dans les 'Schistes de Mondrepuis' à Muno (sud de la Belgique). Bulletin de l'Institut royal des Sciences naturelles de Belgique, Sciences de la Terre, 65, 269-272.

Godefroid, J., 1995b. Les brachiopodes (Pentamerida, Atrypida et Spiriferida) de la fin de l'Eifelien et du début du Givetien à Pondrôme (Belgique, bord sud du Synclinorium de Dinant). Bulletin de l'Institut royal des Sciences naturelles de Belgique, Sciences de la Terre, 65, 69-116.

Godefroid, J. \& Cravatte, T., 1999. Les brachiopodes et la limite Silurien/ Dévonien à Muno (sud de la Belgique). Bulletin de l'Institut royal des Sciences naturelles de Belgique, Sciences de la Terre, 69, 5-26.

Godefroid, J. \& Stainier, P., 1982. Lithostratigraphy and biostratigraphy of the Belgian Siegenian on the south and south-east borders of the Dinant Synclinorium. Courier Forschungsinstitut Senckenberg, 55, 139-164.

Godefroid, J. \& Stainier, P., 1988. Les formations de Vireux et de Chooz (Emsien Inférieur et Moyen) au bord sud du Synclinorium de Dinant entre les villages d'Olloy-sur-Viroin (Belgique) à l'ouest et de Chooz (France) à l'est. Bulletin de l'Institut royal des Sciences naturelles de Belgique, Sciences de la Terre, 58, 95-173.

Godefroid, J., Blieck, A., Bultynck, P., Dejonghe, L., Gerrienne, P., Hance, L., Meilliez, F., Stainier, P. \& Steemans, P., 1994. Les formations du Dévonien inférieur du Massif de la Vesdre, de la Fenêtre de Theux et du Synclinorium de Dinant (Belgique, France). Mémoires pour servir à l'Explication des Cartes Géologiques et Minières de la Belgique, $38,1-144$.

Godefroid, J., Stainier, P. \& Trost, G., 2002. Two new spinocyrtiid brachiopods (Spiriferida) from the Pragian and the Lower Emsian of Belgium. Bulletin de l'Institut royal des Sciences naturelles de Belgique, Sciences de la Terre, 72, 25-41. 
Gosselet, J., 1857. Note sur les Terrains dévoniens de l'Ardenne et du Hainaut. Bulletin de la Société Géologique de France, 2ème série, $14,364-374$.

Gosselet, J., 1874a. Carte géologique de la bande méridionale des calcaires dévoniens de l'Entre Sambre-et-Meuse. Bulletin de 1'Académie royale des Sciences, des Lettres et des Beaux-Arts de Belgique, 2ème série, 37, 81-114.

Gosselet, J., 1874b. Compte-rendu de l'excursion du 7 septembre à Trélon. Bulletin de la Société géologique de France, 3ème série, 2, 681-687.

Gosselet, J., 1877. Quelques documents pour l'étude des Schistes de Famenne. Annales de la Société géologique du Nord, 4, 303-320.

Gosselet, J., 1880. Esquisse géologique du Nord de la France et des Contrées voisines. 1er fascicule : Terrains primaires (texte). Imprimerie Six-Horemans, Lille, $167 \mathrm{p}$.

Gosselet, J., 1887. Notes sur quelques rhynchonelles du terrain dévonique supérieur. Annales de la Société géologique du Nord, 14, 188-221.

Gosselet, J., 1888. L'Ardenne. Ministère des travaux publics, Mémoires pour Servir à l'Explication de la Carte géologique détaillée de la France. Baudry \& Cie, Paris, 889 p.

Gosselet, J., 1894. Étude sur les variations du Spirifer Verneuili et sur quelques espèces voisines. Mémoires de la Société géologique du Nord, 4, 1-61.

Gourvennec, R., 1985. Le genre Howellella (Brachiopoda, Spiriferida) en Europe de l'Ouest au Siluro-Dévonien. Geobios, 18, 143-170. https://doi.org/10.1016/s0016-6995(85)80011-5

Gourvennec, R., 1989. Brachiopodes Spiriferida du Dévonien inférieur du Massif armoricain. Systématique - Paléobiologie - Evolution Biostratigraphie. Biostratigraphie du Paléozoïque, 9, 1-281.

Grabau, A. W., 1923-1924. Stratigraphy of China. Part I, Palaeozoic and older. Geological Survey of China, Peking, 528 p.

Grabau, A. W., 1931-1933. Devonian Brachiopoda of China, I: Devonian Brachiopoda from Yunnan and other districts in South China. Palaeontologia Sinica, Series B, 3/3, 1-545.

Gratsianova, R.T., 1974. 'Shukhertelly' rannevo i srednego Devona po iuge zapadnoi Sibiri: Sistematicheskaia prinadle-zhnost', elementy ekologii i stratigraficheskoie znachenie ['Schuchertellas' of the early and middle Devonian in the south of West Siberia]. In Betekhitina, O.A. (ed.), Sreda i Zhizn v Geologicheskom Proshlom (Paleoekologicheskie Problemy). Akademiia Nauk SSSR Sibirskoe otdelenie, Institut Geologii i Geofiziki (IGIG), Trudy, 84, 77-87.

Greindl, L., 1907. Les Sciences géologiques. In Van Overbergh, C. (coord.), Le Mouvement scientifique en Belgique. 1830-1905. Tome premier. Oscar Schepens \& Cie, Bruxelles, 59-107.

Grunt, T.A., 1989. Otriad Atiridida (evoliutsionnaia morfologiia i istoricheskoe razvitie) [Order Athyridida (evolutionary morphology and phylogeny)]. Akademiia Nauk SSSR, Trudy Paleontologicheskogo Instituta, 238, 1-141.

Grunt, T.A. \& Weyer, D., 2016. New data on some Middle Devonian Athyridida (Brachiopoda) from the Rhenish Massif, Germany. Palaeoworld, 25, 616-631. https://doi.org/10.1016/j. palwor.2016.05.001

Halamski, A.T., 2009. Middle Devonian Brachiopods from the northern Part of the Holy Cross Mountains, Poland in relation to selected coeval faunas. Part One: Introduction, Lingulida, Craniida, Strophomenida, Productida, Protoorthida, Orthida. Palaeontographica, Abteilung A, 287, 41-98. https://doi.org/10.1127/pala/287/2009/41

Hall, J., 1861. Descriptions of new species of fossils from the Upper Helderberg, Hamilton, and Chemung groups. New York State Cabinet of Natural History, Annual Report, 14, 99-109.

Hall, J., 1867. Descriptions and Figures of the Fossil Brachiopoda of the Upper Helderberg, Hamilton, Portage and Chemung Groups. Palaeontology of New York, 4/1, 1-428.

Hall, J. \& Clarke, J.M., 1890. Extract. Palaeontology of New York, vol. 8, part 1. Charles van Benthuysen \& Sons, Albany, 120-137, 160.

Hall, J. \& Clarke, J.M., 1892. An Introduction to the Study of the Genera of Palaeozoic Brachiopoda, Natural History of New York, Palaeontology, vol. 8, part 1. New York Geological Survey. Charles van Benthuysen \& Sons, Albany, 367 p.

Hall, J. \& Clarke, J.M., 1893. An Introduction to the Study of the Genera of Palaeozoic Brachiopoda. Palaeontology of New York, vol. 8, Part 2. Charles van Benthuysen \& Sons, Albany, 394 p.

Harper, Ch.W. \& Boucot, A.J., 1978a. The Stropheodontacea. Part I: Leptostrophiidae, Eostropheodontidae and Strophonellidae. Palaeontographica, Abteilung A, 161, 55-118.

Harper, Ch.W. \& Boucot, A.J., 1978b. The Stropheodontacea. Part III: Stropheodontidae (sensu strictu), Pholidostrophiidae and Lissostrophiidae. Palaeontographica, Abteilung A, 162, 1-80.

Harper, Ch.W. \& Boucot, A.J., 1978c. The Stropheodontacea. Part II: Douvillinidae, Telaeoshaleriidae, Amphistrophiidae and Shaleriidae. Palaeontographica, Abteilung A, 161, 119-175.
Harper, Ch.W., Johnson, J.G. \& Boucot, A.J., 1967. The Pholidostrophiinae (Brachiopoda; Ordovician, Silurian, Devonian). Senckenbergiana lethaea, 48, 403-461.

Harper, Ch.W., Boucot, A.J. \& Walmsley, V.G., 1969. The rhipidomellid brachiopod subfamilies Heterorthinae and Platyorthinae (new). Journal of Paleontology, 43, 74-92.

Havlíček, V., 1975. New genera and species of Orthida (Brachiopoda). Věstník Ústřední ústavu geologického, 50, 231-235.

Helmbrecht, W. \& Wedekind, R., 1923. Versuch einer biostratigraphischen Gliederung der Siegener Schichten auf Grund von Rensselaerien und Spiriferen. Glückauf, Berg- und Hüttenmännische Zeitschrift, 59, 949-953

International Commission on Zoological Nomenclature, 1999 International Code of Zoological Nomenclature, 4th edition. International Trust for Zoological Nomenclature, London, $338 \mathrm{p}$.

Jahnke, H., 1971. Fauna und Alter der Erbslochgrauwacke (Brachiopoden und Trilobiten, Unter-Devon, Rheinisches Schiefergebirge und Harz). Göttinger Arbeiten zur Geologie und Paläontologie, 9, 1-105.

Jahnke, H., 1981. Les brachiopodes Strophodontidae. In Morzadec, P., Paris, F. \& Rachebœuf, P.R. (eds), La tranchée de la Lézais - Emsien supérieur du Massif Armoricain. Sédimentologie, paléontologie, stratigraphie. Mémoires de la Société géologique et minéralogique de Bretagne 24, 149-159.

Jahnke, H., 1986. Superfamille Strophodontacea Caster, 1939. In Rachebœuf, P.R. (ed.), Le Groupe de Liévin. Pridoli-Lochkovien de l'Artois (N. France). Sédimentologie-Paléontologie-Stratigraphie. Biostratigraphie du Paléozoïque, 3, 107-111.

Jansen, U., 2001a. Morphologie, Taxonomie und Phylogenie unterdevonischer Brachiopoden aus der Dra-Ebene (Marokko, Prä-Sahara) und dem Rheinischen Schiefergebitge (Deutschland). Abhandlungen der senckerbergischen Naturforschenden Gesellschaft, 554, 1-389.

Jansen, U., 2001b. On the genus Acrospirifer Helmbrecht et Wedekind, 1923 (Brachiopoda, Lower Devonian) (Contributions to Lower Devonian brachiopods from the Rheinisches Schiefergebirge and adjacent areas, 1). Journal of the Czech Geological Society, 46, 131-144.

Jansen, U., 2014. Strophomenid brachiopods from the Rhenish Lower Devonian (Germany). Bulletin of Geosciences, 89, 113-136. https:// doi.org/10.3140/bull.geosci.1443

Jansen, U., 2016. Brachiopod faunas, facies and biostratigraphy of the Pridolian to lower Eifelian succession in the Rhenish Massif (Rheinisches Schiefergebirge, Germany). Geological Society, London, Special Publications, 423, 45-122. https://doi.org/10.1144/ sp423.11

Johnson, J.G., 2006. Cyrtospiriferoidea. In Kaesler, R.L. (ed.), Treatise on Invertebrate Paleontology, Part H, Brachiopoda, 5 (revised). Boulder and Lawrence, Geological Society of America and University of Kansas, 1722-1732.

Johnson, J.G. \& Hou, H.-F., 2006a. Subfamily Rhynchospiriferinae. In Kaesler, R.L. (ed.), Treatise on Invertebrate Paleontology, Part H, Brachiopoda, 5 (revised). Boulder and Lawrence, Geological Society of America and University of Kansas, 11739-1744.

Johnson, J.G. \& Hou, H.-F., 2006b. Delthyridoidea. In Kaesler, R.L. (ed.), Treatise on Invertebrate Paleontology, Part H, Brachiopoda, 5 (revised). Boulder and Lawrence, Geological Society of America and University of Kansas, 1825-1847.

Johnson, J.G. \& Talent, J.A., 1967. Cortezorthinae, a new subfamily of Siluro-Devonian dalmanellid brachiopods. Palaeontology, 10, 142170.

Kaisin, F., Maillieux, E. \& Asselberghs, E., 1922. Traversée centrale de la Belgique par la vallée de la Meuse et ses affluents de la rive gauche. Congrès Géologique International, Livret-guide pour la XIIIème session, Excursion A2, 90 p.

Kayser, E., 1871. Die Brachiopoden des Mittel- und Ober-Devon der Eifel. Zeitschrift der Deutschen Geologischen Gesellschaft, 23, 491-647.

Kayser, E., 1872. Neue Fossilien aus dem Rheinischen Devon. Zeitschrift der Deutschen Geologischen Gesellschaft, 24, 691-700.

Kayser, E., 1889. Die Fauna des Hauptquarzits und der Zorger Schiefer des Unterharzes. Abhandlungen der Königlich Preussischen geologischen Landesanstalt, Neue Folge, 1, 1-140.

Kayser, E. 1892. Beiträge zur Kenntnis der Fauna der Siegenschen Grauwacke. Jahrbuch der köninglichen preussischen geologischen Landesanstalt, 2, 95-107.

Kayser, E., 1895. Sur une faune du sommet de la série rhénane à Pépinster, Goé et Tilff. Annales de la Société géologique de Belgique, 22, Mémoires, 175-216.

Kelus, W., 1939. Devonische Brachiopoden und Korallen der Umgebung von Pelcza in Volhynien. Biuletyn Pánstwowego instytutu geologicznego, $8,1-51$.

Koninck, L.-G. de, 1855. Notice sur une nouvelle espèce de Davidsonia. Mémoires de la Société royale des Sciences de Liège, 10, 281-288. 
Koninck, L.-G. de, 1876. Notice sur quelques fossiles recueillis par G. Dewalque dans le Système Gedinnien de A. Dumont. Annales de la Société géologique de Belgique, 3, Mémoires, 25-52.

Koninck, L.-G. de, 1882. Description de trois nouvelles espèces famenniennes. Bulletin de l'Académie royale des Sciences, des Lettres et des Beaux-Arts de Belgique, 3ème série, 4, 521-525.

Koninck, L.-G. de, 1887. Faune du calcaire carbonifère de la Belgique. Sixième partie. Brachiopodes. Annales du Musée royal d'Histoire naturelle de Belgique, 14, 1-154.

Kozłowski, R., 1929. Les brachiopodes gothlandiens de la Podolie Polonaise. Palaeontologia Polonica, 1, 1-254.

Kozłowski, R., 1946. Howellella, a new name for Crispella Kozłowski, 1929. Journal of Paleontology, 20, 295.

Krans, Th.F., 1971. The relation between the genera Cyrtinopsis Scupin, 1896 and Kozlowskiellina Boucot, 1957. Leidse Geologische Mededelingen, 47, 99-113.

Lamarck, J.B.P.A. de Monet de, 1816. Histoire naturelle des animaux sans vertèbres présentant les caractères généraux et particuliers de ces animaux, leur distribution, leurs classes, leurs familles, leurs genres, et la citation des principales espèces qui s'y rapportent ; précédée d'une Introduction offrant la Détermination des caractères essentiels de l'Animal, sa distinction du végétal et des autres corps naturels, enfin, l'Exposition des Principes fondamentaux de la Zoologie. Tome 3. Verdière, Paris, $586 \mathrm{p}$.

Lapparent, A. de, 1886. Fossiles caractéristiques des terrains sédimentaires dessinés d'après les collections de l'Université catholique de Paris par Paul Fritel. Premier fascicule : Fossiles primaires. F. Savy, Paris, 10 pls.

Lazarev, S.S., 1990. Evoliutsiia i sistema produktid [Evolution and systematics of productids]. Akademiia Nauk SSSR, Paleontologicheskii Institut, Trudy, 242, 1-171. [In Russian].

Le Hon, H., 1870. Sur quelques espèces nouvelles du devonien [sic] de Belgique. Bulletin de la Société géologique de France, 2e série, 27, 492-499.

Lecompte, M., 1939. Les tabulés du Dévonien moyen et supérieur du bord sud du Bassin de Dinant. Mémoires du Musée royal d'Histoire naturelle de Belgique, 90, 1-227.

Lecompte, M., 1967. Le Dévonien de la Belgique et le nord de la France. In Oswald, D. H. (ed.), International Symposium on the Devonian System, volume 1. Alberta Society of Petroleum Geologists, Calgary, Alberta, 15-52.

Lecompte, M., 1970. Die Riffe im Devon der Ardennen und ihre Bildungsbedingungen. Geologica et Palaeontologica, 4, 25-71.

Legrand-Blain, M., 1995. Relations entre les domaines d'Europe occidentale, d'Europe méridionale (Montagne Noire) et d'Afrique du Nord à la limite Dévonien-Carbonifère : les données des brachiopodes. Bulletin de la Société belge de Géologie, 103, 77-97.

Leriche, M., 1912a. La faune du Gedinnien inférieure de l'Ardenne. Mémoires du Musée royal d'Histoire naturelle de Belgique, 6, 1-58.

Leriche, M., 1912b. Note préliminaire sur la Faune des Schistes de Mondrepuis. - La limite entre le Silurien et le Dévonien dans 1'Ardenne. Bulletin de la Société belge de Géologie, de Paléontologie et d'Hydrologie, 25, Procès-verbaux, 327-333.

Leriche, M., 1948. Sur la faune du Grès de Wihéries (Dévonien inférieur). Bulletin de la Société belge de Géologie, de Paléontologie et d'Hydrologie, 56, 280-298.

Liashenko, A.I., 1957. Novyi rod Devonskikh brakhiopod Uchtospirifer [A new genus of Devonian brachiopods: Uchtospirifer]. Akademiia Nauk SSSR, Doklady 117, 885-888.

Long, S.L. \& Brunton, C.H.C., 2005. The problematic cemented Devonian brachiopod Schuchertellopsis durbutensis Maillieux, 1939. Geobios, 38, 107-112. https://doi.org/10.1016/j.geobios.2003.06.009

Maillieux, E., 1908a. Pentamerus Loëi, espèce nouvelle du Couvinien supérieur Cobm. Bulletin de la Société belge de Géologie, de Paléontologie et d'Hydrologie, 22, Procès-verbaux, 339-340.

Maillieux, E., 1908b. Les gîtes fossilifères de la bande dite 'coblencienne' entre Pesche et Nismes. Bulletin de la Société belge de Géologie, de Paléontologie et d'Hydrologie, 22, Procès-verbaux, 215-231.

Maillieux, E., 1909a. Etude comparative de la répartition des espèces fossiles dans le Frasnien inférieur du bord méridional du bassin dinantais et dans les niveaux synchroniques du Boulonnais. Bulletin de la Société belge de Géologie, de Paléontologie et d'Hydrologie, 23, Mémoires, 115-151.

Maillieux, E., 1909b. Note sur les Pentamères frasniens de la bordure méridionale du bassin dinantais. Bulletin de la Société belge de Géologie, de Paléontologie et d'Hydrologie, 23, Procès-verbaux, 226-234.

Maillieux, E., 1909c. Coup d'œil sur la tranchée du chemin de fer vicinal d'Olloy à Oignies (en construction). Bulletin de la Société belge de Géologie, de Paléontologie et d'Hydrologie, 23, Procès-verbaux, $187-200$.
Maillieux, E., 1909d. Note sur les Cyrtina dévoniennes du bord sud du bassin de Dinant. Bulletin de la Société belge de Géologie, de Paléontologie et d'Hydrologie, 23, Procès-verbaux, 256-260.

Maillieux, E., 1910a. Note sur la faune des roches rouges de Winenne. Bulletin de la Société belge de Géologie, de Paléontologie et d'Hydrologie, 24, Procès-verbaux, 342-354.

Maillieux, E., 1910b. Remarques sur la faune et l'horizon stratigraphique de quelques gîtes fossilifères infradévoniens. Bulletin de la Société belge de Géologie, de Paléontologie et d'Hydrologie, 24, Mémoires, $189-220$.

Maillieux, E., 1910c. Contribution à l'étude de la faune du Dévonien de Belgique. Première note sur les Spirifères. Bulletin de la Société belge de Géologie, de Paléontologie et d'Hydrologie, 23, Mémoires, 323-376.

Maillieux, E., 1910d. Observations sur la nomenclature stratigraphique adoptée, en Belgique, pour le Dévonien et conséquences qui en découlent. Bulletin de la Société belge de Géologie, de Paléontologie et d'Hydrologie, 24, Procès-verbaux, 214-231.

Maillieux, E., 1911. Apparition de deux formes siegeniennes dans les schistes de Mondrepuits. Bulletin de la Société belge de Géologie, de Paléontologie et d'Hydrologie, 25, Procès-verbaux, 176-180.

Maillieux, E., 1912. Texte explicatif du levé géologique de la planchette de Couvin $\mathrm{n}^{\circ} 191$ (pl. 8 de la feuille LVII de la carte topographique). Ministère de 1'Industrie et du Travail, Administration des Mines, Service Géologique de Belgique, Bruxelles, 70 p.

Maillieux, E., 1913. Note préliminaire sur le Couvinien des tranchées de la gare de Jemelle. Bulletin de la Société belge de Géologie, de Paléontologie et d'Hydrologie, 27, Procès-verbaux, 9-16.

Maillieux, E., 1914. Observations sur Cyrtina undosa Schnur sp. et description d'une variété nouvelle. Bulletin de la Société belge de Géologie, de Paléontologie et d'Hydrologie, 28, Procès-verbaux, 2-6.

Maillieux, E., 1922a. The Geology of Belgium, II: The Palaeozoic formations of the southern part of the Dinant Basin. Proceedings of the Geologists' Association, 33 (1), 9-19. https://doi.org/10.1016/ S0016-7878(22)80013-4

Maillieux, E., 1922b. Terrains, roches et fossiles de la Belgique. Les Naturalistes belges, Bruxelles, $164 \mathrm{p}$.

Maillieux, E., 1929. Observations sur un travail de W. Paeckelmann ayant trait, entre autres, à certains conglomérats du Dévonien moyen de la Belgique. Bulletin de la Société belge de Géologie, de Paléontologie et d'Hydrologie, 39, Procès-verbaux, 65-66.

Maillieux, E., 1930. Trois variétés nouvelles de Brachiopodes du Frasnien supérieur. Bulletin de la Société belge de Géologie, de Paléontologie et d'Hydrologie, 34, Procès-verbaux, 106-109.

Maillieux, E., 1931. La faune des Grès et des Schistes de Solières (Siegenien moyen). Mémoires du Musée royal d'Histoire naturelles de Belgique, 51, 1-90.

Maillieux, E., 1932. La faune de l'Assise de Winenne (Emsien) moyen sur les bordures méridionale et orientale du Bassin de Dinant. Mémoires du Musée royal d'Histoire naturelle de Belgique, 52, 1-102.

Maillieux, E., 1933. Terrains, roches et fossiles de la Belgique. Deuxième édition revue et corrigée. Patrimoine du Musée royal d'Histoire naturelle de Belgique, Bruxelles, 217 p.

Maillieux, E., 1936a. La faune et l'âge des Quartzophyllades siegeniens de Longlier. Mémoires du Musée royal d'Histoire naturelle de Belgique, 73, 1-140.

Maillieux, E., 1936b. La Faune des Schistes de Matagne (Frasnien supérieur). Mémoires du Musée royal d'Histoire naturelle de Belgique, 77, 1-74.

Maillieux, E., 1938. Le Couvinien de l'Ardenne et ses faunes. Mémoires du Musée royal d'Histoire naturelle de Belgique, 83, 1-57.

Maillieux, E., 1939. La faune des schistes de Barvaux-sur-Ourthe (Frasnien supérieur). Bulletin du Musée royal d'Histoire naturelle de Belgique, 15/53, 1-8.

Maillieux, E., 1940a. Contribution à la connaissance du Frasnien moyen (Assise de Frasnes) de la Belgique. Bulletin du Musée royal d'Histoire naturelle de Belgique, 16/14, 1-44.

Maillieux, E., 1940b. Le Siegenien de l'Ardenne et ses faunes. Bulletin du Musée royal d'Histoire naturelle de Belgique, 16/5, 1-23.

Maillieux, E., 1940c. Documents pour servir à l'étude du Givetien de l'Ardenne. Bulletin du Musée royal d'Histoire naturelle de Belgique, $16 / 7,1-13$.

Maillieux, E., 1941a. Les brachiopodes de l'Emsien de l'Ardenne. Mémoires du Musée royal d'Histoire naturelle de Belgique, 96, 1-74.

Maillieux, E., 1941b. Répartition des brachiopodes dans le Dévonien de l'Ardenne. Bulletin du Musée royal d'Histoire naturelle de Belgique, $17 / 30,1-14$.

Maillieux, E., 1941c. Note sur la faune de quelques gisements fossilifères éodévoniens de l'Ardenne. Bulletin du Musée royal d'Histoire naturelle de Belgique, 17/9, 1-14. 
Maillieux, E., 1941d. Répartition des Spiriferidae et des Spiriferinidae dans le Dévonien de l'Ardenne. Bulletin du Musée royal d'Histoire naturelle de Belgique, 17/13, 1-6.

Maillieux, E. \& Demanet, F., 1929. L'échelle stratigraphique des terrains primaires de la Belgique. Bulletin de la Société belge de Géologie, de Paléontologie et d'Hydrologie, 38, 124-131.

Malaise, C., 1879. Description de gites fossilifères dévoniens et d'affleurements du terrain crétacé. F. Hayez, Bruxelles, 69 p.

Malaise, C., 1892. Sur les calcaires dévoniens de Sombreffe. Bulletins de l'Académie royale des Sciences, des Lettres et des Beaux-Arts de Belgique, série 3, 23, 371 .

Malaise, C. \& Stainier, X, 1892. Documents concernant le Dévonien du bassin de Namur. Annales de la Société géologique de Belgique, 19, Bulletin, 297-302.

Mamedov, A.B., 1978. Novye predstaviteli Devonskikh Ambocoeliidae (Brakhiopody) Malogo Kavkaza [New Devonian Ambocoeliidae (Brachiopoda) from the Caucasus minor]. Ezhegodnik vsesoiuznogo paleontologicheskogo obshchestva, 21, 197-204. [In Russian].

Marion, J.-M., Geukens, F. \& Lamberty, P., in press. Carte géologique de Wallonie : Sart - Xhoffraix 50/1-2. 1/25 000. Namur, Service public de Wallonie, Belgique, avec une notice explicative.

Maurer, F., 1886. Die Fauna des rechtsrheinischen Unterdevon aus meiner Sammlung zum Nachweis der Gliederung. F. Wirtz, Darmstadt, 55 p.

Maurer, F., 1889. Palaeontologische Studien im Gebiet des rheinischen Devon. 7 Mittheilungen über Synonymen aus der Fauna und Gliederung des rechtsrheinischen Unterdevon. Neues Jahrbuch für Mineralogie, Geologie und Palaeontologie, 1889/2, 149-172.

Mergl, M., 2006. A review of Silurian discinoid brachiopods from historical British localities. Bulletin of Geosciences, 81, 215-236. https://doi.org/10.3140/bull.geosci.2006.04.215

Mergl, M. \& Massa, D., 2005. A new giant discinoid brachiopod from the Lower Devonian of Algeria. Acta Palaeontologica Polonica, 50, $397-402$

Mittmeyer H.-G., 2008. Unterdevon der Mittelrheinischen und Eifeler Typ-Gebiete (Teile von Eifel, Westerwald, Hunsrück und Taunus). In Deutsche Stratigraphische Kommission (ed.), Stratigraphie von Deutschland VI, Devon (coord. and red.: Weddige, K. für die Subkommission Devon). Schriftenreihe der Deutschen Gesselschaft für Geowissenschaften, 52, 139-203.

Mottequin, B., 2005a. Les Brachiopodes de la transition Frasnien/ Famennien dans le Bassin de Namur-Dinant (Belgique). Systématique-Paléoécologie-Biostratigraphie-Extinctions. Unpublished Ph.D. thesis, University of Liège, Liège, Belgium, $427 \mathrm{p}$.

Mottequin, B., 2005b. Revision of the brachiopod Cytina rigauxi Maillieux, 1909 and description of a new ambocoeliid genus (Dionacoelia n. gen.) from the Frasnian of southern Belgium. Bulletin de l'Institut royal des Sciences naturelles de Belgique, Sciences de la Terre, 75, 53-66.

Mottequin, B., 2008a. Late middle Frasnian to early Famennian (Late Devonian) strophomenid, orthotetid and athyridid brachiopods from southern Belgium. Journal of Paleontology, 82, 1052-1073. https:// doi.org/10.1666/07-086.1

Mottequin, B., 2008b. Late Middle to Late Frasnian Atrypida, Pentamerida, and Terebratulida (Brachiopoda) from southern Belgium. Geobios, 41, 493-513. https://doi.org/10.1016/j.geobios.2007.10.008

Mottequin, B., 2008c. New observations on some Upper Devonian brachiopods from the Namur-Dinant Basin (Belgium). Geodiversitas, 30, 455-537.

Mottequin, B. \& Brice, D., 2016. Upper and uppermost Famennian (Devonian) brachiopods from north-western France (Avesnois) and southern Belgium. Geologica Belgica, 19, 121-134. https://doi. org/10.20341/gb.2016.004

Mottequin, B. \& Brice, D., 2019. Reappraisal of some Upper Devonian (Famennian) spiriferide brachiopods from the Band-e Bayan Domain (Afghanistan). Geobios, 52, 47-65. https://doi.org/10.1016/j. geobios.2018.11.003

Mottequin, B. \& Denayer, J., 2015. Pridolian-Lochkovian macrofaunas from southern Belgium and northern France: de Koninck (1876) revisited. Strata, série 1, 16, 101-102.

Mottequin, B. \& Godefroid, J., 2016. Les brachiopodes. In Brice, D. (coord.), Stratotype Givétien. Muséum national d'Histoire naturelle, Paris; Biotope, Mèze, 154-155.

Mottequin, B. \& Poty, E., 2016. Kellwasser horizons, sea-level changes and brachiopod-coral crises during the late Frasnian in the NamurDinant Basin (southern Belgium): a synopsis. Geological Society, London, Special Publications, 423, 235-250. https://doi.org/10.1144/ sp423.6

Mottequin, B. \& Simon, E., 2017a. New insights on TournaisianVisean (Carboniferous, Mississippian) athyridide, orthotetide, rhynchonellide, and strophomenide brachiopods from southern Belgium. Palaeontologia Electronica, 20.2.28A, 1-45. https://doi. org/10.26879/758
Mottequin, B. \& Simon, E., 2017b. Revision of some spiriferide and spiriferinide brachiopods from the historical type area of the Tournaisian Stage (Carboniferous, southern Belgium). Paläontologische Zeitschrift, 91, 473-496. https://doi.org/10.1007/ s12542-017-0359-3

Mottequin, B., Brice, D., Marion, J.-M. \& Simon, E., 2016. Plicathyridine brachiopods (Athyridida) from the Frasnian (Late Devonian) of Western Europe and Middle East. Geobios, 49, 381-393. https://doi. org/10.1016/j.geobios.2016.06.004

Mourlon, M., 1881. Géologie de la Belgique, vol. 2. Savy, Paris; R. Friedländer \& Fils, Berlin; F. Hayez, Bruxelles, 392 p.

Mourlon, M., 1882. Considérations sur les relations stratigraphiques des psammites du Condroz et des schistes de la Famenne propremen dits, ainsi que sur le classement de ces dépôts dévoniens. Bulletin de l'Académie royale des Sciences, des Lettres et des Beaux-Arts de Belgique, 3ème série, 4, 504-521.

Muir-Wood, H., 1962. On the Morphology and Classification of the Brachiopod Suborder Chonetoidea. British Museum (Natural History), London, $132 \mathrm{p}$.

Murchison, R.I., 1840. Description de quelques unes des coquilles fossiles les plus abondantes dans les couches devoniennes du BasBoulonnais. Bulletin de la Société géologique de France, 11, 250257.

Murchison, R.I., Verneuil, E. de \& Keyserling, A., 1845. Géologie de la Russie d'Europe et des Montagnes de l'Oural, vol. 2, pt. 3 , Paléontologie. John Murray, London; Bertrand, Paris, 512 p.

Oehlert, D.-P., 1893. Description de la Rhynchonella ? Gosseleti, Mourlon. Annales de la Société géologiques de Belgique, 20, Mémoires, 125-131.

Orbigny, A. d', 1847. Considérations zoologiques et géologiques sur les Brachiopodes ou Palliobranches. Comptes Rendus Hebdomadaires des Séances de l'Académie des Sciences, 25, 193-195, 266-269.

Paeckelmann, W., 1942. Beiträge zur Kenntnis devonischer Spiriferen. Abhandlungen des Reichsamts für Bodenforschung, 197, 1-188.

Perdigão, J.C., 1973. O Devónico de Barrancos (Paleontologia e Estratigrafia). Comunicações dos Serviços Geológicos de Portugal, $56,33-54$.

Phillips, J., 1841. Figures and descriptions of the Palaeozoic fossils of Cornwall, Devon, and West Somerset. Longman, Brown, Green and Longmans, London, $231 \mathrm{p}$.

Rachebœuf, P.R., 1981. Chonetacés (Brachiopodes) siluriens et dévoniens du Sud-Ouest de l'Europe. Mémoire de la Société Géologique et Minéralogique de Bretagne, 27, 1-294.

Rachebœuf, P.R., 1986. Superfamille Stringocephalacea King, 1850. In Rachebœuf, P.R. (ed.), Le Groupe de Liévin. Pridoli-Lochkovien de l'Artois (N. France). Sédimentologie-Paléontologie-Stratigraphie. Biostratigraphie du Paléozoïque, 3, 136-139.

Rachebœuf, P.R., 1995. The Superfamily Chonetoidea: Catalogue of genera and species. Documents des laboratoires de Géologie de Lyon, 136, 191-238.

Raymond, P.E., 1911. The Brachiopoda and Ostracoda of the Chazyan. Annals of the Carnegie Museum, 7, 215-259.

Renouf, J.T., 1972. Brachiopods from the Grès à Orthis monnieri Formation of northwestern France and their significance in Gedinnian/Siegenian stratigraphy of Europe. Palaeontographica, Abteilung A, 139/4-6, 89-133.

Richter, R. \& Richter, E., 1918. Paläontologische Beobachtungen im rheinischen Devon. Jahrbücher des Nassauischen Vereins für Naturkunde, 70, 143-161.

Rigaux, E., 1873. Notes pour servir à la géologie du Boulonnais. 1. Description de quelques Brachiopodes du terrain Dévonien de Ferques. Mémoires de la Société Académique de l'Arrondissement de Boulogne-sur-mer, 5, 47-60

Robaszynski, F. \& Dupuis, C., 1983. Belgique. Masson, Paris, Guides Géologiques Régionaux, 1-204.

Ryckholt, P. de, 1851. Mélanges paléontologiques, première partie Mémoires couronnés des Savants étrangers de l'Académie royale des Sciences, des Lettres et des Beaux-Arts de Belgique, 24, 1-176.

Ryckholt, P. de, 1854. Mélanges paléontologiques. Deuxième partie. Privately printed, $205 \mathrm{p}$.

Rzhonsnitskaya, M.A., 1980. Novye drevneishie Productellidy iz Devona srednei Azii i Salaira [New early Productellids from the Devonian of Central Asia and Salair]. In Stukalina, G.A. (ed.), Novye Vidy Drevnikh Rastenii i Bespozvonochnykh S.S.S.R. [New species of fossil plants and invertebrates of the USSR], vyp. 5. Nauka, Moscow, 59-61. [In Russian].

Rzhonsnitskaya, M.A., 1983. Sovremennoe sostojanie problemy nizhnego jarusa srednego devona i zadachi Vyezdnoj sessii Komissii MSK po devonskoj sisteme [Recent state of the problem on the Middle Devonian lower stage and the tasks of the field session of the Commission in the Interdepartmental Stratigraphic Committee on the Devonian System]. Akademija Nauk SSSR, Sibirskoe Otdelenie, Institut Geologii I Geofiziki, Trudy, 562, 5-24. [In Russian]. 
Sandberger, G. \& Sandberger, F., 1856. Die Versteinerungen des rheinischen Schichtensystems in Nassau. Mit einer kurzgefaßten Geognosie dieses Gebietes und mit steter Berücksichtigung analoger Schichten anderer Länder. Kreidel \& Niedner Verlagshandlung, Wiesbaden, Lfg. 8 and 9 [edition], I-XV, Bogen 30-71 [sheets printed in the edition], 233-564.

Sartenaer, P., 1957. De l'importance stratigraphique des Rhynchonelles famenniennes situées sous la zone à Camarotoechia omaliusi (Gosselet, J., 1877). Deuxième note : le groupe de la Camarotoechia triaequalis. Bulletin de l'Institut royal des Sciences naturelles de Belgique, 33/20, 1-32.

Sartenaer, P., 1958. De l'importance stratigraphique des Rhynchonelles famenniennes situées sous la zone à Camarotoechia omaliusi (Gosselet, J., 1877). Troisième note : le groupe de la Camarotoechia nux. Bulletin de l'Institut royal des Sciences naturelles de Belgique, 34/23, 1-32.

Sartenaer, P., 1961. Late Upper Devonian (Famennian) rhynchonelloid brachiopods. Bulletin de 1'Institut royal des Sciences naturelles de Belgique, 37/24, 1-10.

Sartenaer, P., 1967. De l'importance stratigraphique des Rhynchonelles famenniennes situées sous la Zone à Ptychomaletoechia omaliusi (Gosselet, J., 1877). Quatrième note : Tenuisinurostrum n. gen. [T. crenulatum (Gosselet, J., 1877) = espèce-type]. Bulletin de 1'Institut royal des Sciences naturelles de Belgique, 43/32, 1-24.

Sartenaer, P., 1968. De la validité de Caryorhynchus Crickmay, C. H., 1952, genre de Brachiopode Rhynchonellide, et de sa présence dans le Frasnien Supérieur d'Europe occidentale. Bulletin de l'Institut royal des Sciences naturelles de Belgique, 44/34, 1-21.

Sartenaer, P., 1969. Late Upper Devonian (Famennian) rhynchonellid brachiopods from western Canada. Geological Survey of Canada, Bulletin, 169, 1-269. https://doi.org/10.4095/106431

Sartenaer, P., 1974a. Que sont les Schistes de Barvaux-sur-Ourthe ? Bulletin de l'Institut royal des Sciences naturelles de Belgique, Sciences de la Terre, 50/5, 1-18.

Sartenaer, P., 1974b. La Zone à Caryorhynchus tumidus, Zone nouvelle de la partie supérieure du Frasnien. Bulletin de l'Institut royal des Sciences naturelles de Belgique, Sciences de la Terre, 50/6, 1-11.

Sartenaer, P., 1974c. Signification stratigraphique du 'niveau des monstres' du Frasnien franco-belge. Bulletin de l'Institut royal des Sciences naturelles de Belgique, Sciences de la Terre 50/7, 1-19.

Sartenaer, P., 1982. The presence and significance of Spirifer bisinus, S. malaisi, S. supradisjunctus, and S. seminoi in Early Frasnian beds of Western Europe. In Sartenaer, P. (ed.), Papers on the FrasnianGivetian boundary. Geological Survey of Belgium, Brussels, 122196.

Sartenaer, P., 1984. Deux genres rhynchonellides nouveaux de la fin du Frasnien. Bulletin de l'Institut royal des Sciences naturelles de Belgique, Sciences de la Terre, 55/8, 1-16.

Sartenaer, P., 1988. Description nouvelle de Calvinaria megistana (Le Hon, 1870) et fixation de la position stratigraphique de ce rhynchonellide de la fin du Frasnien en Belgique et en France. Bulletin de l'Institut royal des Sciences naturelles de Belgique, Sciences de la Terre, 58, 33-57.

Sartenaer, P. \& Plodowski, G., 1975. Importance stratigraphique et répartition géographique du genre rhynchonellide Araratella n. gen. du Famennien supérieur. Bulletin de l'Institut royal des Sciences naturelles de Belgique, Sciences de la Terre, 51/8, 1-34.

Sartenaer, P. \& Plodowski, G., 2003. Reassessment of the Strunian genus Araratella Abramian, Plodowski and Sartenaer, 1975 in the northern Gondwanaland (Rhynchonellida, Brachiopoda). Courier Forschungsinstitut Senckenberg, 242, 329-348.

Schemm-Gregory, M., 2008. A new species of Filispirifer (Brachiopoda: Delthyridoidea) from the Dra Valley, Morocco (Lower Devonian). Zootaxa, 1739, 53-68. https://doi.org/10.11646/zootaxa.1739.1.4

Schmidt, H., 1946. Die Terebratulidae des Wetteldorfer Richtschnittes. Senckenbergiana, 27, 67-75.

Schnur, J., 1851. Die Brachiopoden aus dem Uebergangsgebirge der Eifel. Programm der vereinigten höhern Bürger- und ProvinzialGewerbeschule zu Trier für das Schuljahr 1851. Lintz, Trier, 16 p. https://doi.org/10.5962/bhl.title.14886

Schuchert, Ch. \& Cooper, G.A., 1931. Synopsis of the brachiopod genera of the suborders Orthoidea and Pentameroidea, with notes on the Telotremata. American Journal of Science, series 5, 22, 241-255. https://doi.org/10.2475/ajs.s5-22.129.241

Schuchert, Ch. \& Cooper, G.A., 1932. Brachiopod genera of the suborders Orthoidea and Pentameroidea. Memoirs of the Peabody Museum of Natural History, 4, 1-270. https://doi.org/10.5962/bhl.title.5732

Scupin, H., 1896. Versuch einer Classification der Gattung Spirifer. Neues Jahrbuch für Mineralogie, Geologie, und Paläontologie, 2, 239-248.

Scupin, H., 1900. Die Spiriferen Deutschlands. Palaeontologische Abhandlungen, new series 4, 8, 207-344.

Solle, G., 1963. Hysterolites hystericus (Schlotheim) [Brachiopoda; Unterdevon], die Einstufung der oberen Graptolithen-Schiefer in Thüringen und die stratigraphische Stellung der Zone des Monograptus hercynicus. Geologisches Jahrbuch, 81, 171-220.

Stainbrook, M.A., 1945. Brachiopoda of the Independence Shale of Iowa. Geological Society of America Memoir, 14, 1-74. https://doi. org/10.1130/mem14-p1

Stainbrook, M.A., 1948. Age and correlation of the Devonian Sly Gap beds near Alamogordo, New Mexico. American Journal of Science, 246, 765-790. https://doi.org/10.2475/ajs.246.12.765

Stainier, X., 1887. Note sur un trilobite nouveau et sur les Pentamerus des calcaires d'Humerée. Annales de la Société géologique de Belgique, 14, Mémoires, 75-85.

Steininger, J., 1853. Geognostische Beschreibung der Eifel. Lintz'sche Buchhandlung, Trier, 144 p. https://doi.org/10.5962/bhl.title.15097

Steemans, P., 1989. Etude palynostratigraphique du Dévonien inférieur de l'Ouest de l'Europe. Mémoires pour servir à l'Explication des Cartes Géologiques et Minières de la Belgique, 27, 1-453.

Struve, W., 1965. Beiträge zur Kenntnis devonischer Brachiopoden, 13. Zur Morphologie, Biochronologie und Phylogenie der mitteleuropäischnordafrikanischen Cyrtinopsis-Arten (Spiriferacea). Fortschritte in der Geologie von Rheinland und Westfalen, 9, 7-50.

Struve, W., 1973. Die ältesten Taunus-Fossilien. Natur und Museum, 103, 249-259.

Struve, W., 1992. Neues zur Stratigraphie und Fauna des rhenotypen Mittel-Devon. Senckenbergiana lethaea, 71, 503-624.

Struve, W. \& Werner, R., 1964. Beiträge zur Kenntnis devonischer Brachiopoden, 6: Cimicinella simulatrix n. sp. (Terebratulacea) aus dem Eifelium der Eifel. Senckenbergiana lethaea, 45, 443-453.

Sutton, A.H., 1938. Taxonomy of Mississippian Productidae. Journal of Paleontology, 12, 537-569.

Tsien, H.H., 1971. The Middle and Upper Devonian reef-complexes of Belgium. Petroleum Geology of Taiwan, 8, 119-173.

Vandenven, G., 1991. Explications de la carte géologique du Synclinorium de l'Eifel (Région de Gouvy - Sankt-Vith - Elsenborn). Annales de la Société géologique de Belgique, 113, 103-116.

Vandercammen, A., 1956. Révision des Ambocoeliinae du Dévonien de la Belgique. Bulletin de 1'Institut royal des Sciences naturelles de Belgique, 32/43, 1-51.

Vandercammen, A., 1959a. Contribution à la révision de quelques Spiriferidae de la collection E. de Verneuil. Bulletin de 1'Institut royal des Sciences naturelles de Belgique, 35/4, 1-38.

Vandercammen, A., 1959b. Essai d'étude statistique des Cyrtospirifer du Frasnien de la Belgique. Mémoires de 1'Institut royal des Sciences naturelles de Belgique, 145, 1-175.

Vandercammen, A., 1963. Spiriferidae du Dévonien de la Belgique. Mémoires de l'Institut royal des Sciences naturelles de Belgique, $150,1-179$.

Vandercammen, A., 1968. Cyrtospirifer malaisei (J. Gosselet, 1894) synonyme de Cyrtospirifer bisinus (H. Le Hon, 1870). Bulletin de 1'Institut royal des Sciences naturelles de Belgique, 44/37, 1-12.

Vandercammen, A. \& Vandercammen-Goffinet, I., 1970. Liste des types du sous-ordre des Spiriferida Waagen, W. 1883 (Brachiopoda) conservés à l'Institut royal des Sciences naturelles de Belgique. Bulletin de l'Institut royal des Sciences naturelles de Belgique, 46/38, 1-87.

Van Tuijn, J.F., 1927. Le Couvinien et la partie supérieure de l'Eodévonien $\mathrm{du}$ bord oriental du Synclinorium de Dinant entre l'Ourthe et Ferrières. Mémoires de l'Institut géologique de l'Université de Louvain, 4, 103-262.

Vaughan, A., 1915. Correlation of Dinantian and Avonian. Quaterly Journal of the Geological Society of London, 71, 1-49. https://doi. org/10.1144/gsl.jgs.1915.071.01-04.03

Verneuil, E. de \& Archiac, E.J.A.D. d', 1845. Note sur les fossiles du terrain paléozoïque des Asturies. Bulletin de la Société géologique de France, 2e série, 458-480.

Wallengren, H.D.J., 1882. Revision af Skandinaviens Tipulidae. Entomologisk Tidskrift, series 1, 2, 177-208. [Published for 1881]. https://doi.org/10.5962/bhl.part.5204

Walmsley, V.G. \& Boucot, A.J., 1971. The Resserellinae-a new subfamily of Late Ordovician to Early Devonian dalmanellid brachiopods. Palaeontology, 14, 487-531.

Walmsley, V. G., \& A. J. Boucot. 1975. The phylogeny, taxonomy and biogeography of Silurian and Early to mid-Devonian Isorthinae (Brachiopoda). Palaeontographica, Abteilung A, 148, 34-108.

Williams, A., 1950. New stropheodontid brachiopods. Journal of the Washington Academy of Sciences, 40, 277-282.

Williams, A., 1965. Suborder Strophomenida. In Moore, R.C. (ed.), Treatise on Invertebrate Paleontology, Part H, Brachiopoda, 1. The Geological Society of America and The University of Kansas Press, Lawrence, Kansas, H362-H412.

Williams, A. \& Brunton, C.H.C., 2000. Orthotetidina. In Kaesler, R.L. (ed.), Treatise on Invertebrate Paleontology, Part H, Brachiopoda, 3 (revised). Geological Society of America and University of Kansas, Boulder and Lawrence, 644-681. 
Williams, A, Carlson, S.J., Brunton, C.H.C, Holmer, L.E. \& Popov, L.E., 1996. A supra-ordinal classification of the Brachiopoda. Philosophical Transactions of the Royal Society of London (series B), 351, 1171-1193. https://doi.org/10.1098/rstb.1996.0101

Yolkin, E.A., Kim, A.I., Weddige, K., Talent, J.A. \& House, M.R., 1997. Definition of the Pragian/Emsian Stage boundary. Episodes, 20, 235-240.

Zeiler, F., 1857. Versteinerungen der älteren Rheinischen Grauwacke. Verhandlungen Naturhistorisch Verein Preussischen Rhein, 14, 4551 .

Zhang, M. \& Ma, X., 2019. Origination and diversification of Devonian ambocoelioid brachiopods in South China. Palaeobiodiversity and Palaeoenvironments, 99, 63-90. https://doi.org/10.1007/s12549-018$0333-4$ 